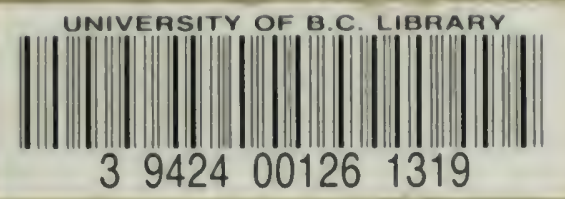

SPRAYING GROPS

STCRAGE ITEN

FROCESSING-ONE

$$
\begin{aligned}
& \text { I p } 1-\text { F } 19 \mathrm{D} \\
& \text { U.B.C. LIBRARY }
\end{aligned}
$$




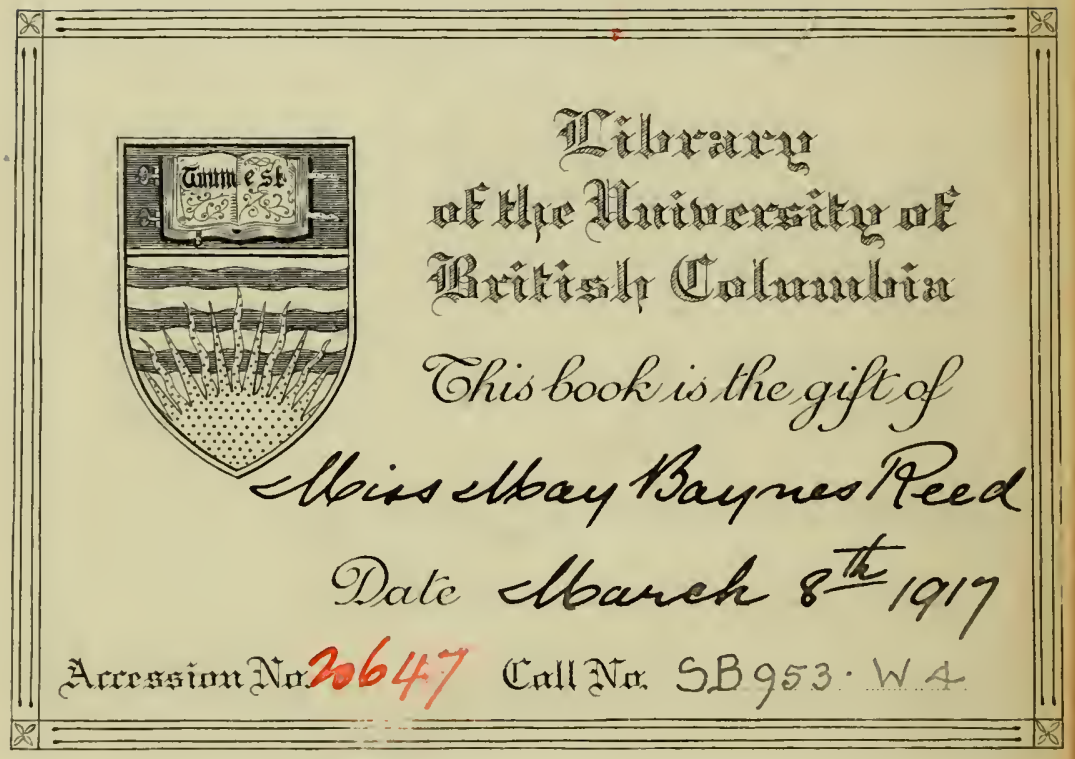




\section{THE LIBRAFY}

The University of British Columbia

Acc No.

Cat. No.

Spraying Crops 

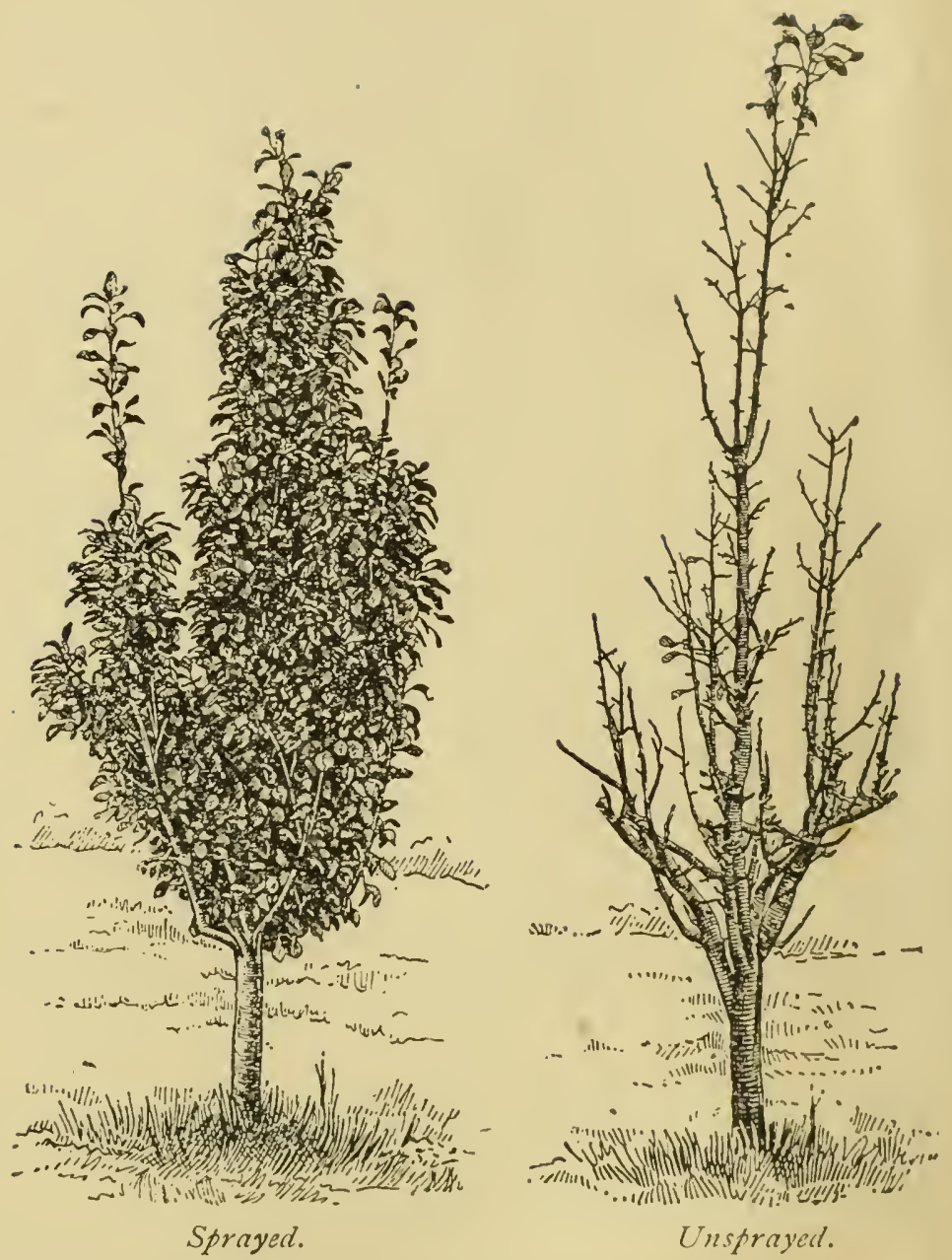

PIATE I. -PEAR IAEAF-BLIGHT EXPERIMENT. 


\section{SPRAYING CROPS}

\section{Why, When, and How}

1i)

\section{CLARENCE M. WEED, D. Sc.}

Professor of Zoölogy and Botany', New Hampshire College of Agriculture and the Mechanic Arts

\section{ILLUSTRATED}

Third (Revised) EdiTion

NEIV YORK

The Orange Judd Company 


\section{BY THE SAME AUTHOR \\ INSECTS AND INSECTICIDES}

A Practical Manual Concerning Noxious Insects and the Methods of Preventing their Injuries. Illustrated. Price $\$ 1.25$.

\section{FUNGI AND FUNGICIDES}

A Practical Manual Concerning the Fungous Diseases of $\mathrm{Cul}$ ivated Plants and the Methods of Pre. venting their Ravages. Illustrated. Price $\$ \mathbf{I} .00$.

Orange Judd Co., New York, N. Y.

TEN NEW ENGLAND BLOSSOMS ANI) THEIR INSECT VISITORS

\section{Illustrated.}

Hougititon, Mifflin \& Co., Boston and New York.

Copyright, I $89 \mathrm{~J}$

by

Clarence M. WEli)
Printed by

Repuibican Press Association

Concord, N. H. 


\section{PREFACE.}

This little manual has been prepared for the purpose of aiding owners of spraying-machines to use them to best advantage. The practical results of the most recent investigations and experiments have been embodied in it; and technical terms, so far as possible, have been excluded.

The development of the practice of spraying crops furnishes a striking illustration of the practical results agriculture may derive from scientific investigation and accurate experimentation. Little more than a decade has passed since Professor A. J. Cook, then of the Michigan Agricultural College, began his experiments in spraying apples to prevent the injuries caused by the Codling Moth-experiments which first proved to the horticultural public that the remedy was safe and sure-and to his enthusiastic advocacy of the process American fruit-growers are largely indebted for the introduction of spraying machinery. The success which followed spraying for the Codling Moth naturally led to experiments in spraying for other insects, and later for fungous diseases; our early knowledge of remedies for the latter being largely due to the efforts of Messrs. Scribner and Galloway, of the United States Department of Agriculture. The establishment of the state experiment stations has 
greatly aided the acquisition and diffusion of information upon the whole subject.

The sources of those illustrations on the following pages which are not original with the author, are indicated in the list below: After Riley, Plates II, IV, V, and figures I, 3, I 4, 2I, 23, 26-28, 30-3I, 3I, 35-38, 40; after Bailey, figures 9, Iо, I 7 ; after Slingerland, figures I 9, 24. 25 ; after Popenoe, figure I 5 ; after Galloway, Plate I and figures 7 , 29; after Chester, figure 8; after Farlow, figure 4; after Garman, Plate III and figure 22; after Jones, figure 34; after Osborn, figure 39; after Saunders, figures I \&, 33.

C. M. W.

New Hampshire College of Agriculture and the Mechanic Arts.

DURHAM, March, $1 \$ 95$.

NOTE CONCERNING BORDEAUX MIXTURE.

Since the main part of this book was printed, Prof. L. H. Bailey has called attention to a "russeting" of apples and pears, apparently due to the application of Bordeaux Mixture. It was most serious when there was not an excess of lime in the Mixture, especially that made with the ferrocyanide of potassium test. On account of this, it is advised that the Mixture be made by formulas giving precise quantities, or at any rate that there be added a sufficient (quantity of lime. 


\section{CONTENTS.}

PAGE

Introduction............................. 9

\section{PART I}

SPRAYING TIE LARGER FRI'I'S

Apple............ 55 Pear........... 69

Plum ............. $\sigma_{3}$ Cherry............ 73

Peach....................... 67 Orange 75

PART II

Siraying SMall Fruits and Nersery Stock

Strawberry .......... Si Grape........... 9 I

Currant and Gooseberry... S6 Raspberry........... 94

Nursery Stock........................... 96

PART III.

Spraying Shade-Trees, Urnamental Plants, and FLoIVERS

Shade-Trees ......... I04 Rose............. I Io Flowers ............................... II

\section{PART IV}

Spraying V'egetables, Field-Crops, and Domestic ANIMALS

Potato............. I $\mathbf{I} 7$ Grain Crops.......... I26

Cabbage............ I22 Domestic Animals....... I 29 
It is certain that spraying for insects and fungous troubles has come to be a necessary labor.-L. H. BAILEY.

Spray! Spray! Spray! Spray for insects and for fungous diseases. This is one of the secrets of successful fruit-gronving.DELaware Farm and Home.

I believe in spraying, for I have tried and proven it. In many' portions of our country to-day it is just as much a necessity as is underdraining, or fertilizing, or killing potato-bugs.-MORTIMER WHITEHEAD.

The most important accession to recent horticultural practice is the spraying of fruit-trees with arsenical poisons for the destruction of various insects.-AMERICAN CULTIVATOR.

The spraying of trees with ar senites is no longer an experiment, but takes its recognized place in the regular routine avork of the fruit-farm.-ORCHARD AND GARDEN.

Out of thirty-six tons of grapes last season I did not lose five pounds by rot, but I shall spray, rot or no rot. Spraying adds greatly to the health of the vines, and consequently to the size and beauty of the fritit.-JOHN BURROUGHS. 


\section{SPRAYING}

CROPS

\section{INTRODUC'TION}

ROWING plants are liable to injury from two T classes of organisms, - namely, noxious insects and parastic fungi. Although these tiny foes are often considered too insignificant to merit serious attention, they annually destroy about $\$ 500,000,000$ worth of crops in the United States. By an intelligent use of the spraying machine-a simple apparatus by which certain substances that destroy insect and fungous life may be distributed over the surfaces of plants-a large proportion of this loss can be prevented at comparatively slight expense. The object of this little manual is to indicate why, when, and how to spray, to get the best results.

The philosophy of spraying will be better understood if one has a general knowledge of the habits and methods of development of the insect and fungous pests against which the spraying-machine is used. Nearly all of these organisms are weaker and easier to destroy at some one period of their existence than at any other; consequently, a knowledge of their habits 
and history is often necessary to success. In the following introductory pages, I have attempted briefly to indicate some of the more important general facts concerning their development.

\section{Spraying Against Insects}

The insect against which the spraying-machine has been most generally used in the northern United States is the Codling MOTH or Apple Worm-the little white worm that one too often finds near the core

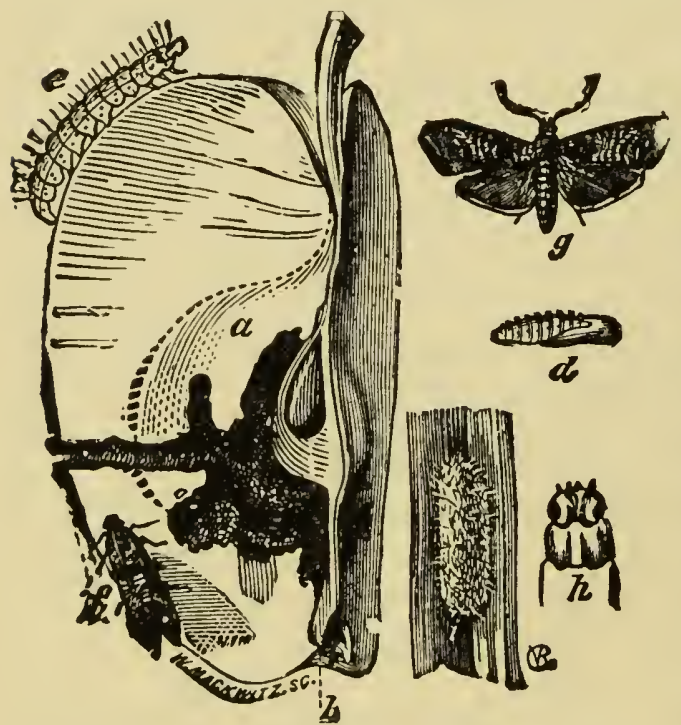
FIG. I. Codling Moth: $a$, injured apple; $b$, peas, until they at-
place where egg is laid; $e$, larva; $d$, pupa $;$ pean the $i$, cocoon $; g, f$, moth ; $h$, head of larva. of the dessert apple. The parent of this little pest is a small chocolate-colored moth (represented at $f$ and $g$, Fig. I), which appears in spring, and deposits eggs in the calyx ends of the young a p ples, from the time they are as large as tain the size of small hickory nuts. These eggs are placed on the outside of the fruit, and each soon hatches into a little worm, which nibbles at the skin, finally biting through, and eating its way toward the core. Once inside it 
continues feeding as the apple develops, constantly increasing in size, until, at the end of three or four weeks, it is about three fourths of an inch long, and appears as represented in $c$. It has now finished its caterpillar growth, and, leaving the apple, it finds some crevice in the rough bark, where it spins a slight cocoon, in which it changes to the pupa or chrysalis state. A fortnight later it emerges from the cocoon as a full-fledged moth, like the one which laid the original egg. Thus the curious life-cycle is completed. There are two broods of the worms each season.

By means of the spraying-machine the fruit-grower is able to place in the calyx ends of the young apples a few particles of poison, so that when the newlyhatched worm nibbles at the skin, the chances are that it will eat one of these particles, and thus cut short at the outset its own career. To do this the fruit-grower usually mixes a quarter of a pound of London purple or Paris green with a barrel of water, and then, having the barrel in a wagon, he drives along the rows of apple trees just after the blossoms have fallen off, and sprays them. The little particles of poison are thus distributed over the tree in a fine mist, and when the water in which they are suspended evaporates, they are left high and dry upon the leaves and fruit, where they remain for several weeks a menace to insect enemies, until the combined action of rain and dew, wind and sunshine, dissipates their poisonous properties. The first brood of worms being thus destroyed, there is no necessity, usually, to spray for the second brood; 
because their would-be parents having died in infancy, the worms of the second brood do not appear upon the scene.

Another insect against which the spraying machine is often used is the Plum Curculio. This pest has been, in years past, the worst enemy of the plumgrower, and is the cause of the worminess and premature dropping of the fruit, with which so many owners of plum trees are familiar. The adult Curculio is a small, hard beetle (shown magnified at Fig. 2,c), which

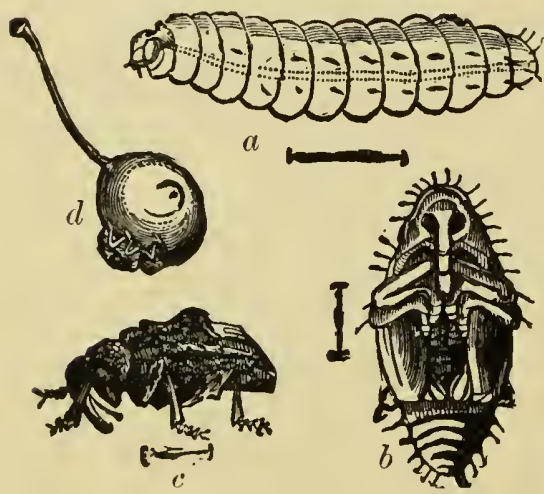
appears in the plum orchard early in spring, and feeds upon the foliage and flowers until the fruit is well formed. It then attacks the young plums, gnawing at them to satisfy its hunger, and cutting crescent-shaped marks in the skin to deFIG. 2. Plum Curculio: $a$, larva; posit its eggs (d). In a $b$, pupa; $c$, beetle, magnified; $d$, short time these eggs plum, showing crescent mark. hatch into little grubs that feed upon the pulp of the fruit, gradually working toward the pit. In a few weeks they become full-grown (a), by which time the infested plums have generally fallen to the ground. The larve then leave the fruit, and, entering the soil a short distance, change to pupx (b). A little while later they again change and come forth as perfect beetles. There is but one brood in the season. 
As the ergss of this insect are deposited bencath the skin of the fruit, it is manifestly impossible to reach the larva by spraying. But by coating the young fruit and foliage with particles of Paris green we can kill the parent beetle before it inserts the egg, and thus the plums will escape. And this is done by many of the leading orchardists of America.

Besides these two insects affecting the fruit of orchard trees, against which the spraying machine is especially used, there are many enemies of the foliage which are open to destruction by similar means. One of the worst of these pests is the CANKER WORM, which at more or less frequent intervals during the last century has scourged both orchard and shade trees in many parts of the United States and Canada. It is represented in its different stages in Fig. 3. The worm or larva hatches from masses of small cylindrical eggs (e) deposited upon the bark of the tree. It feeds upon the parenchyma of the leaves, causing a badly infested tree to appear brown and seared, as if scorched by fire. These worms continue feeding for several weeks before becoming full grown;
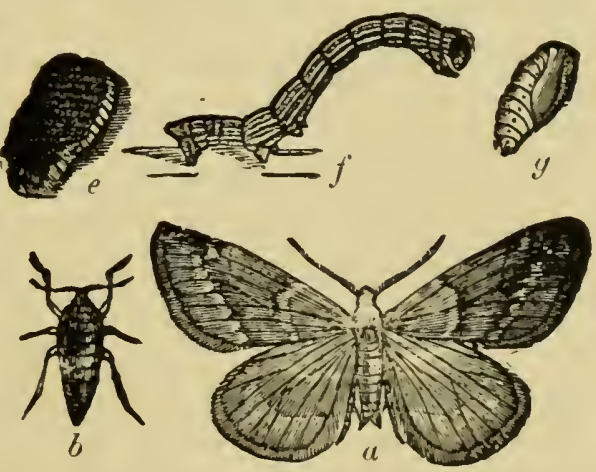
they then descend to FIG. 3 . Canker Worm : $e$, eggs; $f$, larva; the ground, burrow $s$, pupa; $a$, male moth; $b$, female moth. into the soil a short distance, and spin silken cocoons 
within which they change to the pupa or chrysalis state and later emerge as moths. The two sexes of the moths differ greatly: the male $(a)$ has large, well developed wings, while the female (b) is wingless. The latter is of an ash-gray color. On emerging from the chrysalis, she crawls to the base of the tree, and ascending the trunk deposits eggs on the twigs or branches of the tree.

The Canker Worm, with nearly all other leaf-eating caterpillars, falls an easy victim to the spraying-machine.

\section{Feeding Habits of Insects}

Insects take their food in two ways: some bite and others suck. The three species mentioned under the last heading are examples of those insects which take their food by biting, piece by piece, the tissues of leaf, stem, or fruit of their host-plant. Because of this they may be destroyed by placing particles of poison upon the surface of the plant. A large proportion of the injurious insects have such biting mouth-parts; but there is also an important class which have instead of jaws a pointed beak that they push into the cells of the plant, and suck out the sap. Insects of this kind can not be destroyed by coating the food-plant with particles of poison, for such particles will not enter their alimentary system; consequently, one must use against them some insecticide which kills by contact. There are several such insecticides in common use, the most important, perhaps, being insect powder and kerosene emulsion. 


\section{Development of Parasitic Fungi}

Many other instances of the usefulness of the spraying-machine in controlling noxious insects will be found on the later pages of this little book. To illustrate the theory of its use against the fungous enemies of crops, as well as the life-history of the parasitic fungi themselves, we may instance the Down Mildew, which causes the Browr Rot of grapes.

The Brown Rot of grapes is a fungous diseasethat is, it is a diseased condition of the foliage or fruit due to the presence of a fungus. This fungus is a minute, parasitic plant that develops at the expense of the tissues of the grape, thus causing blighting of the leaf and decay of the fruit. It attacks all the green parts of the vine, including the young shoots, as well as the leaves and berries; and, like other fungi, reproduces by means of spores-minute bodies corresponding in function to the seeds of flowering plants.

When one of these spores falls upon a moist leaf its contents divide into a number of distinct particles which escape through an opening in the spore-wall. Each of these particles moves about in the drop of water on the leaf for a few minutes, then comes to a standstill and germinates by sending out a little tubesomewhat as a kernel of corn in moist soil sends out its germinating radicie-and this tube penetrates the epidermis or skin of the leaf. Once inside, the tube continues to grow, pushing about between the cells of the leaf, and forming what is called the mycelium, or 
vegetative portion of the fungus, which may be likened to the roots of the higher plants. As there is little nourishment to be obtained bctween the cells, this myce-

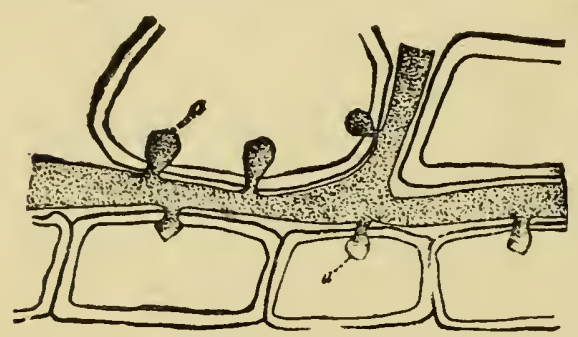

FIG. 4. Section of leaf showing mycellium of fungus. Magnified.

lium develops minute processes which push through the cell walls and absorb the cell contents. A small section of an affected leaf, greatly magnified, is represented in Fig. 4, the unshaded doublewalled spaces representing the leaf cells, the shaded part between the walls the mycelium of the fungus, and the projections marked $a, a$, the processes or suckers that penetrate the cells.

After this mycelium has developed in the leaf for some time, it is ready to produce its spores. Consequently it sends out through the breathing pores or stomata of the leaf its fruiting branches. These bear upon their tips small oval bodies which are the spores. Some of these fruiting branches are shown in Fig. 5. The "mildew" visible to the naked eye is composed of these fruiting branches and their spores. It only develops under certain atmospheric conditions; so that the mycelium may exist in the affected parts of the vine for some time before this outward manifestation of its presence occurs. Besides the spores above described, which are produced during the summer season, and consequently are called summer spores, there 
is developed in autumn a different class of spores, by which the fungus passes through the winter. Hence, these latter are called the winter spores.

It is evident from the above account of this fungous parasite, that remedial or preventive measures are useless after the enemy has become established within the tissues of the plant. But its ingress may be prevented by coating the green parts of the vine with some substance having a destructive effect upon fungous spores. The salts of copper have such an effect, and in consequence have come into general use as fungicides.

From the foregoing illustrations the reader will have learned that spraying is simply an easy and practical Fig. 5. Fruiting branches. Greatly method of distributing cer- magnified.

tain substances having a destructive effect upon insect and fungous life over the outer surfaces of trees, shrubs, vines, and herbaceous plants. These substances are usually applied in a finely powdered condition, and the tiny particles stand guard over the plants, killing with remorseless certainty any insect or fungous pest that attempts to pass through their 
lines to reach the plant. The particles themselves do not enter the plant, but remain on the outside until driven off by the combined action of wind, rain, dew, and sunshine. This is not true, however, of the contact-killing insecticides, which are applied directly to the offending insects, and do not remain on the plant in an effective condition.

Substances used to destroy insects are called insecticides; those used to destroy fungi are called fungicides.

\section{Insecticides used in Spraying}

The insecticides used in spraying may be broadly divided into two classes: (I) internal poisons, or those which take effect by being eaten along with the ordinary food of the insect; and (2) external irritants, or those which act from the outside,-closing the breathing pores, or causing death by irritation of the skin. The most important insecticides are the poisons. Of these the most popular are the combinations of arsenic, known as Paris green and London purple.

Paris green is a chemical combination of arsenic and copper, containing about 55 or 60 per cent. of arsenic. It is almost insoluble in water; but there is often a small percentage of it soluble, and to prevent the injury this may do to foliage it pays to add a little fresh lime water (made by slaking fresh lime in water) to the spraying mixture. It may be used in spraying potatoes, apple trees, and most shade trees, at the rate 
of + ounces to 50 gallons of water. On stone fruits, especially peach, use half this strength, unless lime is added. Paris green is a heavy powder, and does not stay long in suspension: hence it must be kept constantly stirred to prevent its settling to the bottom of the vessel. Buy Paris green in as finely powdered condition as possible, and get it of a reliable dealer.

London purple generally contains nearly the same percentage of arsenic as Paris green; but the arsenic is often in a more soluble form, and consequently London purple is more likely to injure foliage than Paris green, unless lime is added. It is a finer powder than the green, and remains in suspension in water longer. It is also cheaper. Before using, the soluble arsenic should be made insoluble by the addition of lime water. One of the best ways to do this is to add three fourths of a pound of lime to a pound of London purple, and thoroughly mix them in a gallon of hot water, allowing the mixture to stand two hours and keeping it hot during this time if it can be conveniently done. In this way the soluble arsenic will be rendered insoluble, and the London purple may be used at the rate of 4 or 5 ounces to a barrel of water. Or the London purple may be added to the water as usual, and about 2 gallons of fresh milk of lime (made by slaking lime in water) strained into the barrel. If allowed to stand an hour, all the soluble arsenic is more likely to be rendered insoluble than if used at once. After London purple has been thus treated with lime it can safely be applied to tender foliage at 
a strength of 4 ounces to 50 gallons of water. Both London purple and Paris green may be added to the Bordeaux mixture ( 4 ozs. poison to 50 gallons mixture), as described more fully on page 33 , and then the treatment with lime is not necessary.

Hellebore is a vegetable poison, and kills both by contact and by being eaten. It may be applied in water, I ounce to 3 gallons, or I lb. to a barrel. It is especially excellent in destroying the imported currant worm.

Pyrethrum, or Insect Powder, is made from the powdered flowers of plants of the genus Pyrethrum. The greatest obstacle to the use of Pyrethrum has been the difficulty in obtaining the pure, fresh article. After long exposure to the air it loses much of its insecticidal value. It is used mainly as a dry powder or in water ( $\mathrm{I}$ ounce to 3 gallons); but may also be used in the form of a tea, or a decoction, a fume, or an alcoholic extract diluted.

Kerosene Emulsion.-There are two methods of preparing this in common use,-one originating with Messrs. Riley and Hubbard, and the other with Prof. A. J. Cook. Both have their advocates. According to the former it is prepared by adding 2 gallons of kerosene to I gallon of a solution made by dissolving $1 / 2$ pound of hard soap in I gallon of boiling water, and churning the mixture by forcing it back into the same vessel through a force-pump with a rather small nozzle until the whole forms a creamy mass, which will thicken into a jelly-like substance on cooling. 
The soap solution should be hot when the kerosene is added, but of course must not be near a fire. The emulsion thus made is to be diluted before using, with nine or ten parts of water to one part of emulsion. The amount of dilution varies with different insects. Soft water or rain water should be used in diluting. If this cannot be obtained add a little lye or bicarbonate of soda; or prepare according to one of the following methods.

Professor Cook has two formulas,-one where soft soap is used and the other for hard soap. He describes them as follows :

Cook's Soft Soap Emulsion.-—"Dissolve I qt. of soft soap in 2 qts. of boiling water. Remove from fire and, while still boiling hot, add I pint of kerosene and immediately agitate with the pump as described above. In two or three minutes the emulsion will be perfect. This should be diluted by adding an equal amount of water, when it is ready for use. This always emulsifies readily with hard or soft water; always remains permanent, for years, even, and is very easily diluted, even in the coldest weather and without any heating. In this last respect it has no equal, so far as we have experimented. The objections to it are,-We cannot always procure the soft soap, though many farmers make it, and it is generally to be found in our markets. It occasionally injures the foliage, probably owing to the caustic properties of the soap. We have used this freely for years, and never saw any injury till the past season. In case of any such trouble, use only one 
half the amount of soap-one pint instead of one quart. It works just as well."

Cook's Hard Soap Emulsion._-"Dissolve 1/4 lb. of hard soap,-Ivory, Babbitt, Jackson, or whale oil, etc.,-in 2 quarts of water; add, as before, I pint of kerosene, and pump the mixture back into itself while hot. This always emulsifies at once, and is permanent with hard as well as soft water. This is diluted with twice its bulk of water before use. The objection to a large amount of water sinks before the fact that this secures a sure and permanent emulsion even though diluted with hard water. This also becomes, with certain soaps, lumpy or stringy when cold, so that it cannot be readily diluted with cold water unless first heated. Yet this is true with all hard soap emulsions in case of certain soaps. We can, however, always dilute easily if we do so at once before our emulsion is cold, and we can also do the same either by heating our emulsion or diluent, no matter how long we wait."

When the undiluted emulsion, however made, is to be kept for fucure use, store it in a cool, dark place. When desired for use measure out the required amount and mix it with three or four parts of boiling water. Then add cold water to fill out the dilution.

Pyrethro-Kerosene Emulsion.- A combination of kerosene and Pyrethrum has lately proven very effective in destroying plant-lice and similar pests. It may be made by mixing $\mathrm{I} / 4 / 4 \mathrm{lbs}$. Pyrethrum powder with three quarts of kerosene in a light vessel. Allow this to stand four days: then add to 3 gallons of boil- 
ing soap-suds (made by dissolving I lb. of soap in 3 gallons of water), and pump forcibly into the same vessel for ten minutes. This makes an emulsion that may be diluted with 150 parts of water, and yet be effective as an aphis destroyer.

Fish-oil Soap.-Professor J. B. Smith and others report excellent results in the use of this substance against plant-lice and similar insects. The soap is on the market at about 12 cents a pound, but, according to Professor Smith, it can be made much more cheaply by the following formula:

Hirsh's crystal potash lye

Fish oil .

Soft water
I pound.

3 pints.

3 gallons.

Dissolve the lye in the water, heat to boiling, and then add the oil. It should be boiled about two hours, and when done water can be added to make up for the loss by evaporation. For use as an insecticide it is made into a dilute suds by dissolving $\mathrm{I} l \mathrm{lb}$. of soap in 8 gallons of water. It is less liable to injure foliage than kerosene emulsion.

Lime Spray is made by slaking a half-peck or a peck of fresh lime in water, and pouring into a barrel nearly full of water, straining the lumps out as it enters the barrel. By means of this and the spray pump, trees and vines may be literally whitewashed. It is useful in mechanically coating plants so that certain insects will not molest them.

Tobacco Decoction. - This is made by boiling refuse 
tobacco stems or dust in water, or pouring boiling water over them. This gives a concentrated liquid, which is to be diluted with cold water, until there are two gallons of water for each pound of tobacco used. It is a good remedy for plant-lice. A stronger formula, recommended by Mr. M. V. Slingerland, is to steep 5 pounds of tobacco stems in 3 gallons of water for 3 hours; then strain and dilute with enough water to make 7 gallons, when the decoction is ready to use.

Whate Oil Soap.-Dissolve in water at the rate of two ounces soap to one gallon water. This is good to destroy plant-lice, rose slugs, etc.

\section{Fungicides used in Spraying}

The principal fungicides used in spraying are certain salts of copper, especially the sulphate of copper and the carbonate of copper. These substances were first experimented with on a large scale in France, and gave such satisfactory results that they were adopted in a practical way by many vineyardists. In America they have been used for this purpose only about a decade; yet, thanks to numerous investigations and experiments, their efficacy is well attested, and they are in practical use over a large territory. Their principal combinations are indicated below:

Bordeaux Mixture.-This fungicide originated in France, and has become one of the leading combinations of copper salts. Since its introduction into America there has been a constant tendency to dilute the mixture more and more. The results from the 
diluted mixtures have been apparently as good as from those of full strength, and of course the cost has been proportionately lessened. The different formulas are indicated below:

Standard or 22-Gallon Formula.-Dissolve 6 pounds copper sulphate in I gallon hot water in an earthern or wooden vessel. In another vessel slake 3 pounds fresh lime in one gallon water. Strain the latter, and add to 20 gallons water. Now pour in the dissolved copper sulphate and mix thoroughly. Keep the mixture stirred while using. This strong mixture is now seldom used.

Fifty-Gallon Formula.-In r889, while at the Ohio Experiment Station, I experimented with potato blight by diluting this mixture a little more than half, using 6 pounds copper sulphate and 4 pounds lime to $5^{\circ}$ gallons water, instead of 22 gallons. This was applied to a number of plants besides potatoes, and apparently gave as good results as undiluted mixtures. The same formula was also successfully used in r 890 , and has been quite generally adopted since, although the following dilute formula is probably better for general use, except early in the season.

Sezienty-five-Gallon or Dilute Formula.-In I89 I, Mr. IV. J. Green of the Ohio Experiment Station, used on apples, plums, pears, cherries, raspberries, etc., a still more dilute mixture, viz., 4 pounds copper sulphate and 4 pounds fresh lime to 50 gallons water, and obtained very good results. 'The cost of the copper sulphate in a barrel of this mixture is less than one 
third the cost of that in a barrel prepared according to the original formula. Successful results have been obtained with even weaker mixtures.

Mr. Green recommends the following method of making the mixture: "Dissolve the copper sulphate in 2 gallons of hot water, and pour into the barrel or tank used in spraying, after which fill the tank nearly half full of cold water. Slake the lime in another vessel and pour into the copper sulphate solution, straining through a brass wire strainer with about 30 meshes to the inch. The lime will not dissolve readily; hence, after pouring off each time, more water is to be added to the lime and poured off as before, until nearly all the lime is dissolved, or taken up in suspension, which is really the case. Water to make 40 or 50 gallons in all is then to be added.

Granulated copper sulphate should be purchased as it is much easier to dissolve than the crystalline form. Be sure to use freshly burned stone lime, which will slake into fine particles, without coarse granules. Wooden vessels should always be used in preparing the mixture.

The Bordeaux mixture begins to deteriorate within a few hours after being made, and should therefore be applied as soon as possible. It should never be allowed to stand as long as twenty-four hours before using.

Mixing zerith Stock Solutions.-In cases where large areas are to be sprayed several practical experts recommend the use of stock solutions in making the 
Bordeaux mixture. Mr. M. B. Waite grives the following directions concerning this method: "A barrel holding 50 gallons should be selected and 100 pounds of copper sulphate (large crystals may be used) suspended in a basket or piece of coarse sacking in the upper part of it. The barrel is then filled with water. In a day or two all the copper will be dissolved. The basket is then removed and more water is added until the barrel is again full. 'This second addition of water is necessary to fill the space which was occupied by the copper before it was dissolved. Each gallon of this solution will contain two pounds of the copper salt.

"The lime may also be kept ready mixed for use. It should be slaked and run off as a paste, and should then be stored in barrels buried in the ground. A tight barrel should be placed beside the copper sulphate barrel, and filled about one fourth full of the lime paste, and then water should be added until the barrel is nearly full.

"In making up the Bordeaux mixture it is only necessary to draw off the required amount of copper solution and pour it into the tank while it is being filled with water. When the tank is nearly full add several pailfuls of the milk of lime, obtained by stirring the lime paste and water together, allowing it to settle a few minutes and then dipping it off. By using the yellow prussiate of potash test it is easy to determine when sufficient lime has been added. The operator soon learns the correct color of the mixture, and this serves 
as a guide as to when to make the test. All the material which goes into the tank should be strained through a sieve."

The Ferrocyanide Test._-Several authorities have recommended the use of a solution of ferrocyanide of potassium to determine when the proper quantity of lime water has been added to the copper sulphate solution. A half ounce of the ferrocyanide of potassium is dissolved in two or three ounces of water; a few drops of this solution is then added to the mixture. As long as this addition causes a brownish color more lime is needed. When sufficient lime has been added a bluish precipitate is formed.

"One of the best tests for the mixture is simply to notice the color. If too little lime is added it turns a greenish blue; if a slight excess is used the color is a beautiful sky blue, and this is the color the mixture should show. If a great excess of lime is added the mixture takes on a slightly purplish shade of color, especially after standing a few hours." 1

A special advantage of the Bordeaux mixture is, that London purple or Paris green can be added to it, making a combined insecticide and fungicide.

Care should be taken not to use the Bordeaux mixture on fruit crops too late in the season. Traces of it remain for some time, notwithstanding numerous rains, and are liable to cause unnecessary suspicions when on marketed fruit. When a fruit crop requires treatment within a month of the time of picking, it is 
better to substitute some fungicide like eau celeste or carbonate of copper, but it is doubtful if even these combinations should be applied so near the time of the fruit harvest. With nearly, if not quite all our fruit diseases, treatment should begin early and not continue too late. ${ }^{1}$

The experience of many orchardists during the summer of $r 894$, indicates that there is danger in using of Bordeaux mixture on apples after the fruit turns down on the stem, because of its apparently causing a "russeting" of the fruit. It is possible that this was partially due to frosts.

It sometimes happens that traces of Bordeaux mixture remain upon the fruit, even when a considerable interval elapses between the last application and the ripening of the fruit. Such traces may be easily removed by dipping in a solution made by adding two gallons cider vinegar to ten gallons water. A good way is to have three tubs, one holding the vinegar mixture and the other two pure water. Then place the grapes or other fruit in wire baskets holding fifteen to twenty pounds, dip them in the vinegar tub for five minutes and then rinse in the two tubs of clear water, afterwards spreading the fruit on frames or shelves, something like those used in the fruit evaporators. Grapes can be treated in this way on a large scale for six cents a hundred pounds.

Eau Celeste. - This is made by dissolving 2 pounds

${ }^{1}$ Any one desiring further information concerning the Bordeaux mixture is referred to Bulletin No.6, Division of Vegetable Pathology, U. S. Department of Agriculture. 
copper sulphate in 2 or 3 gallons of hot water in an earthen or wooden vessel (such as the large crocks used for butter, or wooden pails or tubs), then adding I quart of ammonia and mixing with 50 or 60 gallons of water. This fungicide has been quite generally replaced by the Bordeaux mixture. It is liable to injure foliage.

Modified Eau Celeste.-Dissolve I pound sulphate of copper in hot water; in another vessel dissolve $\mathrm{r} / 4$ pounds sal soda in hot water; when cool mix the two solutions thoroughly, then add I quart ammonia and dilute to 25 gallons water.

Carbonate of Copper.-This is commonly used in the form of an ammoniacal solution made by dissolving 4 ounces carbonate of copper in 2 quarts of ammonia, and then adding to a barrel ( $5 \circ$ gal.) of water. To prevent loss from evaporation of ammonia, the dissolved carbonate should be added to the water immediately before spraying. It is a simple fungicide, easy to make and apply, and as it is a clear solution, there is no trouble with its clogging nozzles. It has been successfully used to prevent apple scab and various mildews.

A combination of carbonate of copper and carbonate of ammonia, recommended by Prof. F. D. Chester as superior to the above, is made as follows: "Mix together 3 ounces carbonate of copper and I pound pulverized carbonate of ammonia. Dissolve this mixture in 2 quarts hot water and add to 50 gallons water." $\Lambda$ barrel of this mixture costs 12 cents. 
Professor Chester also reports good results from copper carbonate prepared as follows: "Thoroughly mix in half a pail of water, 1 pound of carbonate of copper, to which is added 3 ounces of common glue dissolved in hot water, then dilute to 25 gallons." It would probably be better to dilute to $5^{\circ}$ gallons.

Sulphate of Copper.-Besides its use in combination with other substances, copper sulphate is often applied to vines and trees early in spring to destroy the winter spores of fungi. For this purpose it is used in a simple solution made by dissolving 2 pounds copper sulphate in $5^{\circ}$ gallons water.

Extremely dilute solutions-one part of copper sulphate to r, 000 parts of water-have been used to advantage in greenhouses to check such diseases as carnation rust.

Potassium Sulphide.-Dissolve 1/2 ounce of potassium sulphide (liver of sulphur) in I gallon of hot water. When cold apply in a spray. Used to prevent gooseberry mildew and similar diseases.

Soda Hyposulphite.-Dissolve $1 / 2$ ounce or 1 ounce soda hyposulphite in $\mathrm{r}$ o gallons water. This is recommended by some for gooseberry mildew and apple scab, but it is not in general use.

Lyc Solution.-Professor Wm. B. Alwood recommends a solution of 8 cans of concentrated lye in $5^{\circ}$ gallons water for spraying on trees and vines early in spring, before the buds are started, to kill fungous spores. If applied after buds are started much damage might result. 
Caution.-Most of these copper compounds corrode tin and iron. Consequently, in preparing them for use, earthen, wooden, or brass vessels should be employed; and in applying them the parts of the pump which come in contact with the liquid should be made of brass.

\section{Combinations of Insecticides and Fungicides}

Soon after fungicides came into prominence in this country, the writer called attention ${ }^{1}$ to the advantages of so combining them with insecticides that both may be applied at the same time and in the same mixture. Before then, entomologists had worked out remedies for insects, and botanists remedies for plant diseases, but very little had been done in so combining the treatment that the practical man might, so to speak, "kill two birds with one stone." In the article referred to I said:- "The necessity of treatment for both classes of injuries is at once apparent to all who have experienced the serious losses due to these agents. Obviously, it is of little use to save a plum crop from the curculio, if it is to be destroyed by the fungous disease known as fruit rot; to save raspberries from the slug if they are to be ruined by anthracnose; to save the grape buds from the flea beetle if the berries are to be destroyed by black rot; or to save a pear crop from the ravages of the codling moth and curculio if it is to be distorted and disfigured by the scab; or, to take an example which will strike home to a large proportion of American farmers, it is scarcely worth 
while to save the potatoes from the Colorado beetle if they are to be rumed by a more serious enemy-the potato blight. While the necessity for preventing, so far as possible, injuries to both these classes of organisms is obvious, it is almost equally evident that there will be a great loss of time and labor if each is treated separately. For instance, the farmer who sprays his potatoes with the arsenites two or three times for the beetles, and then goes over them again with solutions of copper sulphate for the blight, would have accomplished the same end in half the time by mixing the copper sulphate and London purple or Paris green in one solution and applying them together. The same is true of the treatment of apples, pears, plums, and, in fact, of a large proportion of the crops liable to injury by both insects and fungi."

Since the above was written a great many experiments along the lines indicated have been made, and we now have a number of satisfactory combinations. Chief among these are the following:

Bordeaux Mixture and Arsenites.-Add 4 ounces London purple or Paris green to 50 gallons of dilute Bordeaux mixture. This is one of the very best combined insecticides and fungicides. It can be used safely and effectively upon a great variety of crops, - such as potatoes for Colorado beetles and blight, apples and pears for insects and scab, and plums for curculio and leaf or fruit diseases. The remarks on page 26 concerning late applications of the Bordeaux mixture are equally applicable to this combination. Arsenites and Copper Carbonate.-The Ohio Experi- 
ment Station recommends the following combination: Paris green 2 ounces, carbonate of copper 2 ounces, dissolve in 3 pints of ammonia, add $\frac{1}{2}$ pound lime and I barrel of water. It is advised that this be substituted for the arsenite and Bordeaux combination for the later sprayings of apples, pears, plums, etc., so as to avoid the lime coating on the fruit.

Care must be taken in combining the arsenites with other fungicide solutions, as one is liable thus to produce a compound very injurious to foliage. Paris green or London purple added to simple solutions of copper sulphate, or to ammonia compounds without lime, injures foliage vastly more than in simple water mixture.

\section{Cost of Spraying Materials}

The average retail and wholesale prices of the various materials used in the spraying mixtures above described are approximately indicated in the following table :

Wholesale. Retail.

Per lb. Per lb.

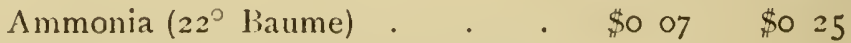

Carbonate of copper (precipitated)

35

60

Carbonate of ammonia

$10 \quad 30$

London purple

$06-07$

10-1 5

Paris green

I8

Pyrethrum

22-40

40-70

Soda hypo-sulphite . . . . 09

20

Sal soda.

or $1 / 4$

05

Sulphate of copper (granulated)

$05-07$

10-15

White hellebore

12

25

Whale oil soap

OS- IO 


\section{Prejudice Against Spraying}

It is quite natural that when most people first learn that the fruit they eat has at some time in its history been sprayed with poison they should object on hygienic grounds. Both in Europe and America the development of the practice of spraying has been accompanied by occasional scares, the last one on this side of the water occurring in September, $\mathbf{1} 89 \mathbf{I}$, when the people of New York, Boston, and other eastern cities were agitated by an exaggerated "grape scare," due to the finding of particles of Bordeaux mixture on some of the grapes in the New York market. But when the spraying, either with the insecticides or fungicides now commonly in use, is done with proper reference to the time, methods, and conditions of treatment, there is no danger to the consumer. Both practical experience and chemical tests have demonstrated that apples sprayed early in the season with Paris green or London purple retain none of the poison at the time of ripening. The most recent demonstration of this appears in the last report of the experimental farms of Canada. A peck of Rhode Island Greening apples that had been sprayed twice with Paris green (one pound to two hundred gallons of water) were carefully gathered, without rubbing, and tested for arsenic. "The process to which they were submitted is one that affords extremely accurate results, and is considered the most delicate of all for the detection of arsenic. It is capable of revealing the presence of one 
fifty-thousanth part of a grain of arsenic. If twentythree thousand bushels of apples contained two and a half grains of arsenic, the minimum fatal dose for an adult, the poison could have been detected by this method." Notwithstanding the most careful analysis no traces of poison were found; and, in conclusion, the chemist states,- "I. am of the opinion that further experiments of this nature would only serve to corroborate this negative result, and to prove that there are no grounds on which to base a suspicion that our sprayed apples are poisonous. The insoluble character of this poison precluding its assimilation by the apple, if such were possible, the infinitesimal part of Paris green that can remain on the apple, the frequent rains subsequent to the spraying,-all go to substantiate the argument that there is not the slightest danger of poisoning in using sprayed apples." .

There is abundant evidence of a similar nature concerning the use of copper salts on grapes. In France, where a large proportion of the grape crop is converted into wine, elaborate investigations have shown that practically none of the copper salts are present in wine from sprayed vineyards. Prof. B. Fallot, of the School of Agriculture at Montpelier, in recording the results of one of these investigations, says,- "The figures obtained have proved once more that wines, after the grapes have received numerous treatments with large quantities of salts of copper, contain scarcely a trace of this substance, and are entirely harmless." 


\section{Spraying Apparatus}

The chief requisites of a good spraying-machine are that it be durable, easily worked, not too expensive for the purpose desired, that it throw a fine spray and have a good-sized cylinder, and that the reservoir holding the liquid be large enough for the purpose intended. For fungicides the parts touching the liquid should be made of brass. Although ten years ago there was scarcely an implement for this purpose upon the market, there are scores of them to-day, and several manufacturers handle them exclusively. They may be had in all shapes, styles, and sizes, from the small hand-spray pump to be used with a bucket, and costing a dollar or two, up to the large horsepower geared ma-
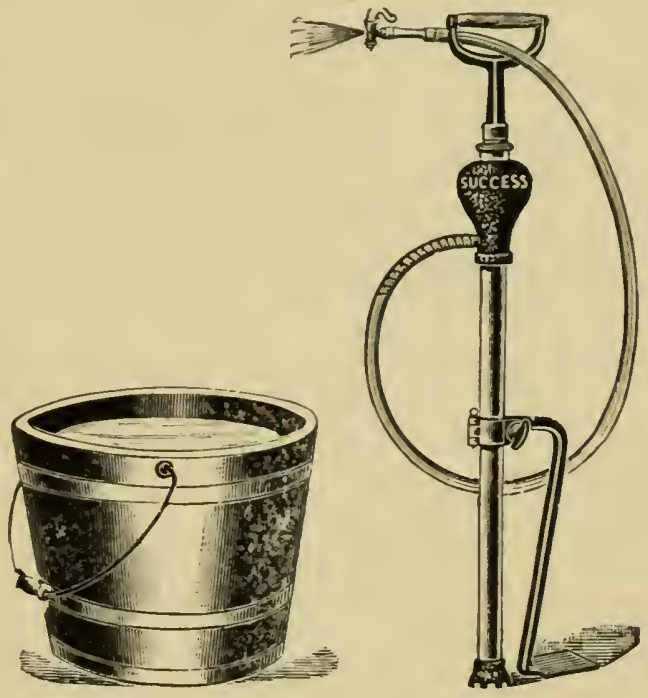

FIG. 6. Bucket Pump. chine costing fifty times as much.

There are four general styles of spraying-machines upon the market. First, we have the small bucket pumps (Fig. 6) that serve a useful purpose where only a comparatively small amount of spraying is to be 
done; then come the knapsack sprayers, one of which is illustrated by Fig. 7, which are especially useful in spraying small vineyards and crops where a horse can-

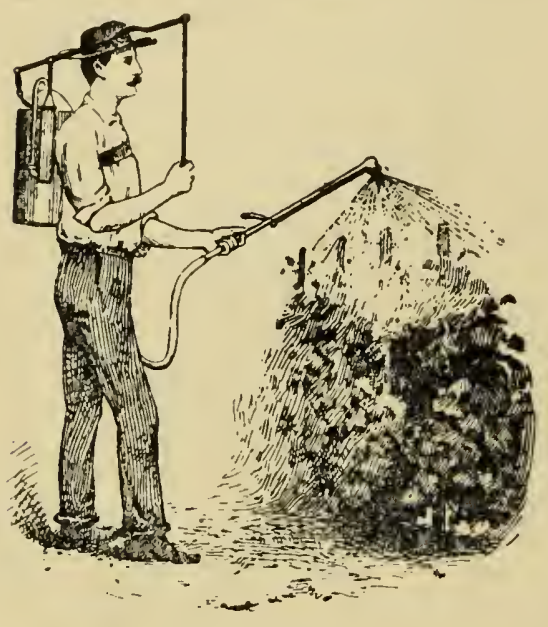

FIG 7. The Knapsack Sprayer. not well be driven; third, we have what may be called the barrel class of sprayers, being good-sized pumps to be attached to barrels mounted in various ways; and, finally, there are the large geared machines working automatically by horse-power. For the general purposes of the average farmer or fruit-grower the barrel machines are much the most useful. They are also of moderate cost, ranging from $\$ 8$ to $\$ 16$. They can be used in spraying all sorts of crops, and may well be mounted on separate wheels, as in the Chester sprayer shown below, or the barrel may be placed in a wagon when in use.

A cheap and efficient home-made spraying cart, designed by Prof. F. D. Chester, is illustrated in Fig. 8. According to Professor Chester, "It can be made by any wheelwright, and consists of a truck mounted upon a pair of carriage wheels. Upon this is placed a barrel holding fifty gallons, held in place by a strap, which surrounds the same and which is tied in front 
at either trace. The barrel has a tight-fitting cover, firmly strapped in place; "pon this is seated the pump. In the large cover is an opening, covered by a lid for filling. Any good force-pump can be used upon the

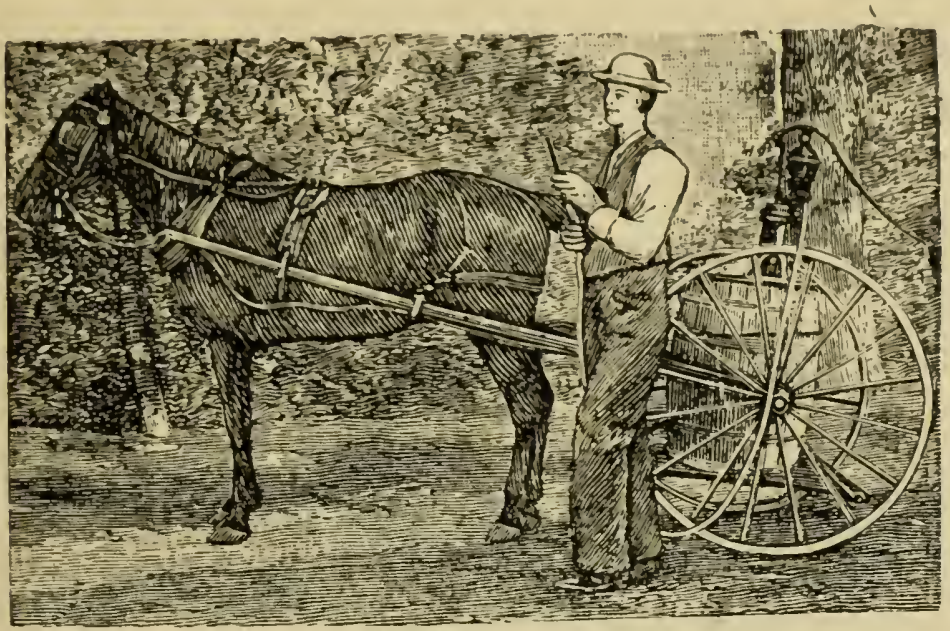

FIG. 8. The Chester Sprayer.

barrel, but it is important that it should be good, and the cheapest are in the long run the dearest. The cheaper iron pumps are excellent at first, but will soon corrode where caustic fungicides are used, even with the best of care. All metallic parts that have contact with the fungicides should be of brass. The pump should have a double discharge, one for the spray and another to return a portion of the fluid back to the barrel to keep the same agitated." The pump should have a hose attached, i 5 to 20 feet long, with a good spray-nozzle at the end.

For work in the nursery as well as many other 
places an excellent spraying outfit "can be made by firmly fastening a barrel, end up, on a sled made of heavy durable timber. Mount upon the barrel a good strong, double-acting force-pump provided with twohose attachments, to each end of which fasten 25 feet of $1 / 2$ inch hose. To the end of each hose attach a Vermorel nozzle: then with the necessary gearing for hitching the horse, the outfit is complete. For oper-

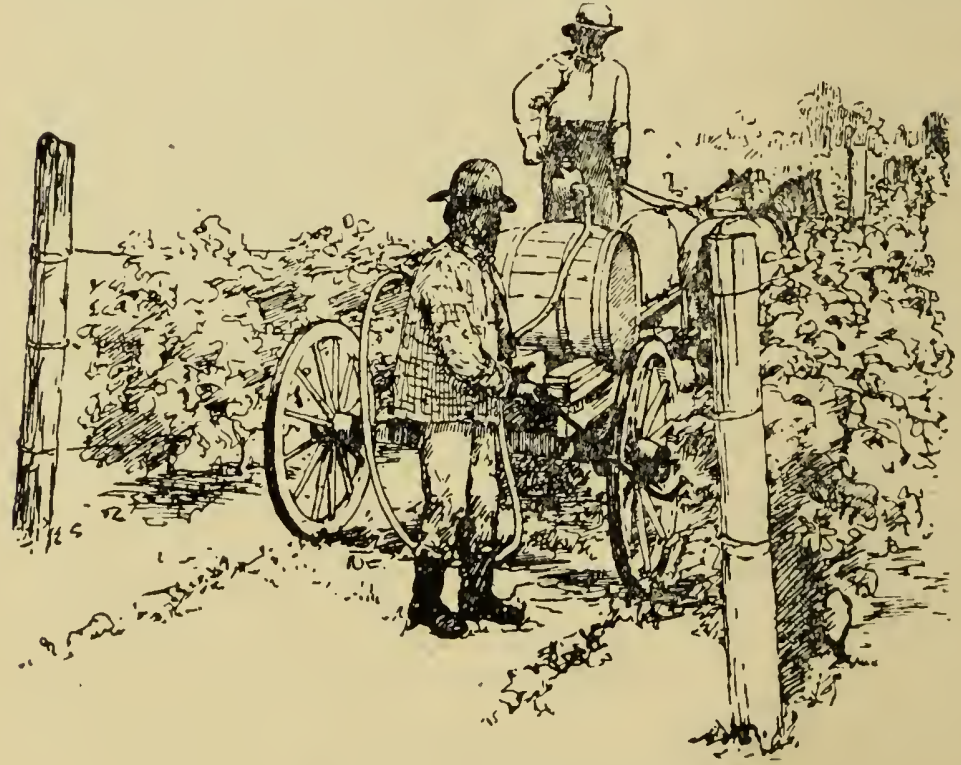

FIG. 9. Spraying Grapes.

ating the machine two men and a horse are required. One man does the pumping and attends to the horse, while the other walks behind and directs the spray over two rows at a time." 1

A good outfit for use in the vineyard, recommended 
by Professor Bailey, is illustrated in Fig. $9 . \quad \Lambda$ barrel with pump is mounted crosswise on the wagon, "and the driver rides and pumps. Another man walks behind and throws the spray up under the vines and on to all the clusters by means of a Vermorel nozzle attached to a half inch gas pipe. This gas pipe has somewhat the form of a slim letter $\mathrm{S}$, the nozzle being attached to one terminal crook, the other crook resting over the man's left arm. The hose is attached near the shoulder. The pipe is so long that the operator is not obliged to stoop, and he can direct the spray in any direction, while the apparatus hangs easily upon

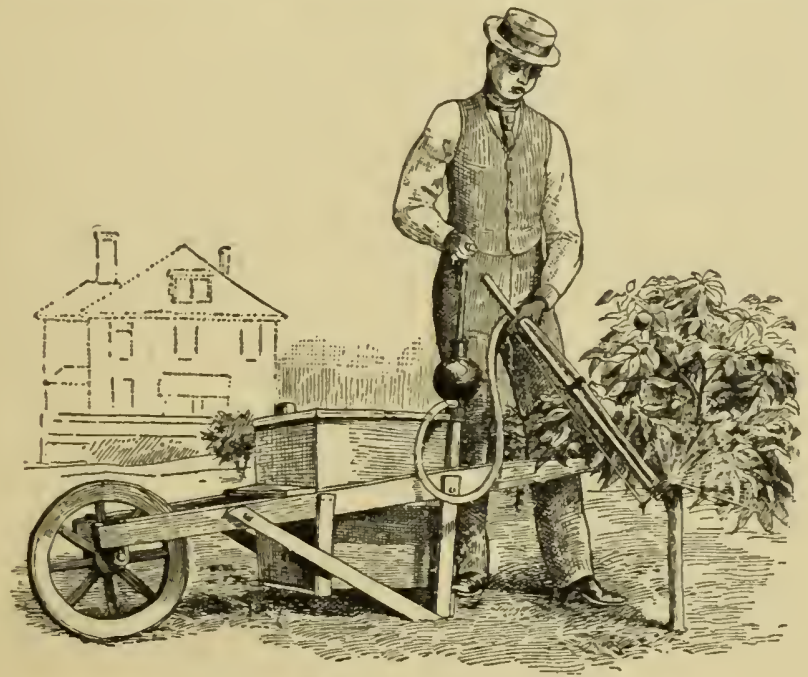

FIG. IO. Method of Spraying Bushes.

the arm. A globe valve just below the arm enables the operator to shut off the stream at will."

A handy, home-made, wheelbarrow spraying outfit, 
gotten up by Professor Bailey, is illustrated in Fig. 10. It is useful in garden work, especially in spraying small bushes. A Cyclone, Vermorel, or Bordeaux nozzle is used to underspray the foliage.

The nozzle forms an important part of the spraying outfit. There are many varieties of these upon the market; some of them are better adapted to certain

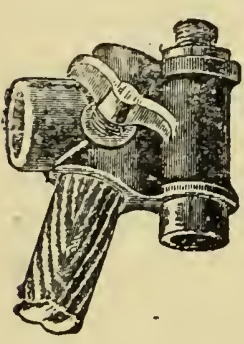

FIG. II. Pole attachment. kinds of work than others, so that it pays to have several forms on hand where there is a variety of spraying to be done. Some of the best forms are the Vermorel, Bordeaux, Climax, Cyclone, Graduating Spray, Deming, Eureka, and McGowan. For spraying large trees, some method of raising the nozzle nearly to the top is generally necessary. The commonest way of doing this is to fasten the nozzle and hose to a long pole; some dealers make a special device for inserting the pole (Fig. I I); but a better way is to use a half inch gas pipe or a brass tube, I 2 or 14 feet long, attaching the hose at one end and the nozzle at the other, or one of the bamboo extensions manufactured

FIG. 12. Spray Pipe Extension.

by some spraying firms. One can also get a handy arrangement for underspraying low bushes, one form of which is shown in Fig. 13 . 


\section{Cost of Spraying}

The cost of spraying depends, of course, upon various conditions, such as the crop sprayed, number of applications, apparatus, and mixture used, etc. It is usually estimated that full-grown orchard trees can be

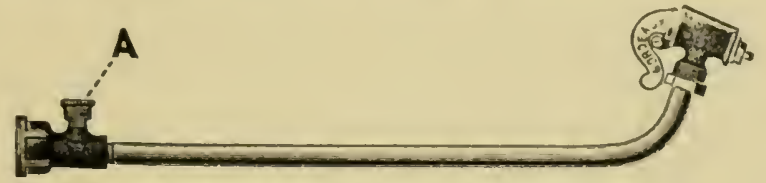

FIG. I3. Underspraying Attachment.

sprayed at a cost of $I_{5}$ to 25 cents per tree per season, while nursery trees can be treated with Bordeaux mixture the first two seasons for about 25 cents per thousand trees per season.

Professor L. R. Jones, of the Vermont Station, has summarized several seasons' experience of the expense of spraying potatoes as follows: "It is impossible to give a general estimate that will suit all cases, as there are so many varying conditions. The amount of the mixture necessary to cover an acre will vary all the way from 50 to 300 gallons, according to the amount of foliage and the methods of application. Where we have covered an acre with $5^{\circ}$ gallons in the middle of July, we have used 100 or I 50 gallons per acre on the same piece in August. Again, in the latter part of August, we have sprayed a poor piece of half-blighted plants with roo gallons per acre, and on the same day, on another piece where the ground was covered with a mass of luxuriant leaves, we have found it neces- 
sary to use fully 250 gallons per acre. Again, *** the number of applications varies with seasons. In I89 I, a single application, made August 20, was sufficient on a piece of late potatoes, while in 1892 three applications were necessary. In general, we should plan for making three applications on all except very early or very late potatoes. These three applications will require from 200 to 500 gallons of the mixtureon the average 400 gallons-used (in Vermont) as follows: ioo gallons per acre the last of July, i 50 gallons per acre the middle of August, I 50 gallons per acre the last of August. This estimate is for a field planted about May I 5 to May 20 , and which will yield 200 bushels per acre. In our work it has taken (for three applications) about 2 gallons of mixture per bushel of yield. On early potatoes a fourth application may sometimes be necessary to keep off the early blight, the first application being made the first week in July; in this case it will take about $2 \mathrm{r} / 2$ gallons per bushel of yield. The mixture costs us about $3 / 4$ cent per gallon, as follows :

5 pounds blue vitriol at 7 cents, 35 cents. 5 " lime at $1 / 2$ cent, . . $2 \mathrm{t} / 2$ cents.

Total cost of 50 gallons weak mixture, $371 / 2$ cents.

"As most potato growers have to pay a little more than this for blue vitriol, one cent per gallon is about the average cost. The cost of applying also varies much, depending upon luxuriance of growth of plants, and upon apparatus used. In our work, with a barrel pump, three men and one horse have sprayed an acre 
well in two hours, when water was convenient, or at the rate of five acres per clay, making the expense of labor about \$1 per acre. Others with similar apparatus have said they could cover ten acres a day."

The cost of spraying one acre of potatoes three times is summarized thus :

200 to 500 gallons at I cent each, Minimum. Maximum. Average. Labor,

$$
\begin{aligned}
& \$ 2.00 \quad \$ 5.00 \quad \$ 4.00 \\
& \frac{\mathrm{I} .50}{\$ 3.50} \quad \frac{3.75}{\$ 8.75} \quad \frac{3.00}{\$ 7.00}
\end{aligned}
$$

"When we consider our gain of an average of I I 3 bushels per acre, worth last fall 80 cents per bushel, or $\$ 90.40$, the profit is great even at the maximum expense."

\section{Profits of Spraying}

The profit of spraying has been abundantly demonstrated in nearly all parts of the United States. The benefit derived is usually so marked that the man who tries the method becomes its enthusiastic advocate. In most cases there is not only a greatly increased crop, but the quality of the crop is so improved that it commands a higher price; and in the case of vines, or any plants living more than one year, the plant is kept in a vigorous condition that enables it to store up vitality for the following crop. In Ohio it has been demonstrated that spraying can easily advance the value of the apple crop \$20 per acre; and in many states it has been shown that spraying is the salvation of the grape-grower. In Vermont it has been demon- 
strated that the potato crop can be increased more than I 00 bushels per acre by spraying, while in New York it proves equally profitable to the nurseryman. In California, fruit-growers generally have adopted it with very gratifying results. Mr. D. W. Coquillett records an instance where a pear-grower actually lost $\$ 2,000$ one season because he neglected to spray to prevent codling moth attack. At the Cornell Experiment Station an increase in cash value of $\$$ I a barrel on sprayed over unsprayed apples was obtained. There are many secondary profits in spraying besides the prevention of actual damage. The fruit becomes much larger in size; consequently the yield is greatly increased, as is also the market value of the product. The same is true of potatoes. The keeping qualities are also very much improved-an item of great practical importance. And according to Mr. B. T. Galloway, the application of Bordeaux mixture has on many plants the effect of a tonic, irrespective of its fungicidal value.

\section{Spraying and the Weather}

According to Professor J. B. Smith, spraying with the arsenites alone "should not be done in the middle of a very hot day, nor, if it can be avoided, on a very hot sultry day. A hot sun on recently sprayed foliage will bring out all the caustic property in the poison applied, and will cause injury. $\Lambda$ fter the moisture has evaporated, and only the thin film of dry poison remains, the sun does not act further on it. On a cool 
day spray at any hour. On a hot day spray during the early morning or late in the afternoon."

Frequent rains often occur during the spraying season, and fruit-growers are sometimes tempted to defer operations till dry weather, but according to the experience of Mr. W. J. Green, it is better, in the case of the Bordeaux mixture at least, "to keep the work going than to wait for dry weather. Of course it would be impracticable to spray during a rain-storm, nor would it be best to spray immediately before, but if the mixture has two or three hours in which to dry before a rain, it will adhere so closely that but little of it will be washed off. Much of it will remain for weeks, even during rainy weather."

\section{Spraying Trees in Blossom}

It is commonly believed that spraying trees in blossom, in case the arsenites are used, endangers the lives of the bees visiting the blossoms. In some regions laws to prevent this have been enacted. Spraying at such times seems unnecessary, and intelligent fruitgrowers would not practise it. The bees are essential to the production of fruit, and there is no excuse for destroying them.

\section{Pruning Trees}

To use the spraying machine to best advantage the orchard should be carefully and intelligently pruned. On this point Mr. E. G. Lodeman writes:" "The pruning and spraying of fruit trees are two subjects ${ }^{1}$ Cornell University Experiment Station, Bulletin 48. 
which are closely related. This is especially true in the case of the apple. Moisture is favorable to the development of the apple-scab fungus. When the tops of trees consist of a tangled mass of large and small branches, they are much longer in dying out than when they are open. Not only is a shelter given to fungi, but their growth is encouraged, and each tree becomes the distributing centre of some disease. The mischief is also aggravated by the fact that it is as difficult for any remedies to gain an entrance, as it is for the light and air. It is impossible to spray such trees to advantage, even granting that the fruit borne by them would warrant the expense. The head of the tree should be open, so that all parts may be reached easily with the spray." The presence of these useless branches also requires the application of much more of the spraying compound than is otherwise necessary, thus involving a decided waste of time and material. By all means prune your orchards properly before you spray them.

In planting new orchards, the trees should be set so far apart that when full-grown they may easily be sprayed. They should not be nearer together than 40 or 42 feet each way.

\section{A Spraying Calendar}

Dr. Wm. C. Sturgis, of the Connecticut Experiment Station, has published the following provisional calendar of the spraying operations for the year. As the author says, it is, of course, impossible to give accurate 
dates for various sprayings, on account of the difference in latitudes and seasons. But the dates are approximate, and the calendar has a decided value.

Fannary and Felmuary. But little can be done during these miclwinter months in the way of spraying, though a great deal by way of preparation. If it has not already been done at the proper time, cut out and burn the black knot of plum and cherry now, and destroy all neighboring wild cherry trees which are knotty. In the latter part of February do all necessary trimming of vines and fruit trees, unless this has been done in the autumn. Where anthracnose has previously attacked grapevines, raspberries, or blackberries, prune severely, cut out every trace of diseased wood or cane and burn it. . . In open winters, February is none too early to go over the orchard carefully and collect and burn all leaves and fruit from diseased trees, such as mummified cherries, plums, and peaches, scabby or rotted pears and quinces, and all blighted leaves. Remember that on the first warm day the air will be full of the germs of plant diseases from these fruits and leaves, if they are not destroyed. Do not use them for bedding or mulch, and do not throw them into the pig-pen.

March.-The middle or end of this month will see everything ready for winter treatment (copper sulphate, I lb. to 25 gals. of water). Select a warm day, or, if possible, sereral days of warm, melting weather. In. some seasons winter treatment can hardly be made before April. 'This treatment is especially good for 
diseases of apple, pear, and quince, for anthracnose and for the black rot of grapes. Where the latter has occurred the previous year, ploughing between the rows, in order to cover up diseased berries, will be found of great advantage.

April.-Put all spraying apparatus in thorough order. Clean and rinse pumps, oil all bearings, see that the valves work well, and test the tubing for leaks. If the winter treatment has been deferred until this month, see that it is finished before the middle of the month.

May.-This is usually the flowering month for vines and fruit trees, and the first application of Bordeaux mixture or other fungicide should immediately precede the opening of the flowers. Use your own judgment. Apples are generally in bloom by the second week in May; quinces, pears, and grapes usually not until somewhat later. The importance of these early treatments can hardly be over-estimated. Watch to see when the petals begin to fall; and make a second application within a few days of that date.

Fune.-The first part of June usually marks the fall of the flowers of most fruit trees. Never spray while trees and vines are in full bloom. Make the second application as soon as the petals have fallen. This will be late in May or early in June, for apples; a week or ten days later for other fruit trees and grapes. Make the June treatment thorough. . . . A good general rule to follow after the second spraying is to let each additional treatment be made from ten days to three weeks after the preceding one; the shorter interval if 
there are heavy washing rains; the longer if the weather is comparatively dry.

Fuly.-This month will close the treatment for most diseases. To avoid the spotting of grapes by the Bordeaux mixture, the two applications during the latter part of this month should consist of the ammoniacal solution of copper carbonate. Early in the month spray for black rot of quinces, and continue treatment every two weeks until the last of August.

August.-The spraying season closes this month. For leaf-blight of strawberries, mow the leaves late in July or early in August, and after allowing them to dry where they lie, set fire to them and burn the bed over. Thoroughly clean and oil all spraying apparatus, and see that it is carefully stored.

September, Oitober, and Norember.-The months of harvest. When picking fruit let one or two boys follow and clean the trees of all diseased and mummified fruit, collecting it in baskets to burn. At the same time gather and burn, as far as possible, all diseased fruit which has fallen. In November clean the orchard thoroughly of fallen leaves, especially if disease has been prevalent, and burn them. Better to destroy them now than in the spring, when the fungous fruit will have come to maturity in and on the leaves.

December.-The black knot fungus matures during December and January; attack it early in the former month. Use the pruning knife unsparingly, cutting out two or three inches above and below each knot. Burn every knot and paint the wound over at once. 


\section{Spraying Precautions}

The man who uses a spraying-machine assumes a responsibility which he has no right to neglect. Some precautions to be taken are indicated below.

Always label all poisonous preparations in plain large letters, POISON. Never leave poisonous compounds within the reach of children, ignorant persons, or domestic animals. Never spray trees in blossom.

In using a compound with which you have had no experience, and which is reported as at all liable to injure foliage, use only aeak mixtures, and, of possible, try its effects first on a small sacte.

If possible own a spraying-pump yourself. If you have to wait to borrow your neighbor's, the chances are that you will begin too late.

Spray in time; begin early; do not wait until the horse is stolen and then try to lock the door by spraying.

Do not spray indiscriminately, anything and everything. Adapt your means to your ends. Study the enemies of your crops and then fight them intelligently.

Of two mixtures equally effective, choose the one least liable to injure foliage. Take the trouble to add a little lime to arsenite mixtures.

Never spray ripening fruit.

Always remember that spraying requires the exercise of skill, judgment, and knowledgre, to get the best results. 


\section{PART I}

SPRAYING THE LARGER FRUITS 


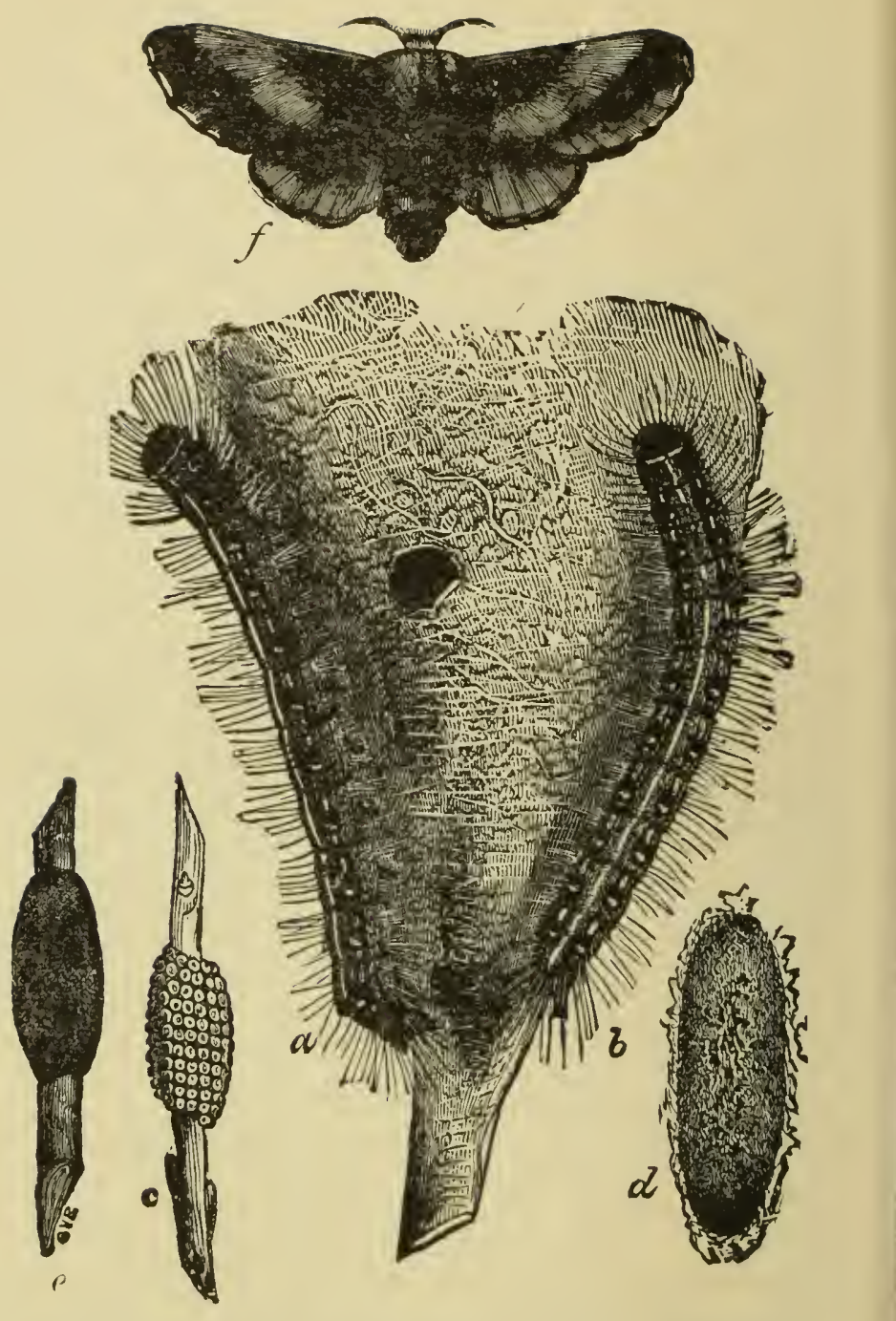

PLATE IJ.-Transformations of the Tent Caterpillar. 


\section{THE APPLE}

Insect Enemies of the Trunk and Branches

A piece of bark covered with the scales of the OySTER-SHELL BARK-LOUSe is represented in Fig. I4. If one of these scales be raised early in the spring, there will be found beneath it a mass of yellowish or whitish eggs, which hatch about the middle of May into small lice, that appear as mere specks to the

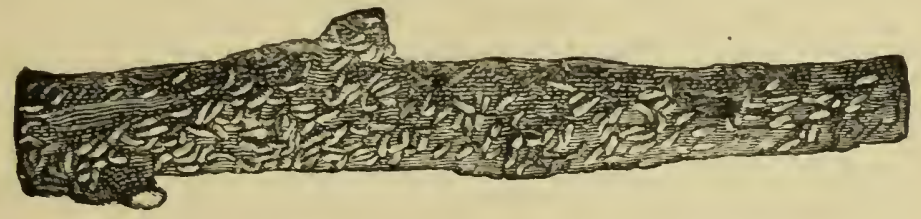

FIG. I4. Oyster-shell Bark-louse.

naked eye. These move about over the bark a few days, when they fix themselves upon it, inserting their tiny beaks far enough to reach the sap. Here they continue to increase in size, and by the end of the season have secreted scaly coverings.

REMEDIES.-During the winter and early spring scrape the trunk and larger branches with a hoe, and then thoroughly scrub with a scrub-brush dipped in a solution made by adding one part of crude carbolic acid to seven parts of a solution made by dissolving one quart of soft soap, or one fourth of a pound of 
hard soap, in two quarts of boiling water. Then in May or June, soon after the young lice have hatched, spray with kerosene emulsion. When the lice are young they are very readily destroyed by this substance.

There are frequently found on the limbs and trunks of young apple trees, masses of a white, woolly substance, beneath which are small, yellowish plant-lice. This is the Woolly ApHis. There are two forms of the insect, one attacking the roots, the presence of which may be easily detected by the knotty appearance of the infested rootlets, and one attacking the limbs and trunk. Like other aphides, these insects multiply rapidly during the summer months, by giving birth to living young. They injure the tree by sucking out its sap through their tiny beaks. They are especially liable to infest young trees, or those which are unhealthy.

Renedies.-When on the trunk and limbs spray with kerosene emulsion; on roots apply hot water, or kerosene emulsion, or dig in refuse tobacco powder and stems.

\section{Insect Enemies of the Fruit}

The insects affecting the fruit of the apple, which may be fought by spraying, are the Codling Moth, and the Plum and Apple Curculios. Of these, the Codling Moth or Apple Wory is the most destructive, and is, in fact, the most generally injurious apple insect. Its life history has already been described in the Introduction (page ro). 
The Apres Curcuiro is a small, dull-brown, hard shelled bettle, with a long snout and four peculiar warts on its back. The beetles drill holes in young apples, both for food and the deposition of eggs. The latter are laid at the bottom of the cavity, and soon hatch into grubs or larva that feed upon the pulp of the fruit. They usually penetrate to the core, where they continue feeding four or five weeks, when they become full grown and pupate within the cavity of the apple. Two or three weeks later they emerge as perfect beetles, which pass the winter under boards or rubbish. The fruit attacked by this pest becomes dwarfed, gnarly, and ill-shapen. Apples are often seriously injured by the Plum CURCUlio, which works in a way similar to the apple curculio. Its life history is described on page $\mathrm{r} 2$.

REMEDIES.-The injuries of these three insects, as well as of several others of minor importance, may be prevented by spraying with London purple or Paris green. Spray first as soon as the blossoms have all fallen, and again about ten days later. In localities where the curculios are very injurious, one or two more sprayings may often be made to advantage at intervals of two weeks, especially on late varieties. It will pay to add lime to the spraying solution (see p. 20), unless the arsenite is combined with Bordeaux mixture, which has the same saving effect.

The poison is supposed to take effect in the case of the codling moth by destroying the young larvæ just after hatching, and while attempting to nibble through 
the skin; while with the curculios it takes effect upon the parent beetles, thus preventing the deposition of eggs.

\section{Insect Enemies of the Foliage}

A large variety of insects feed upon apple foliage. Many of them are caterpillars of moths, and are easily destroyed by spraying. Among the most injurious of these are the CANKER WORnis, of which we have two distinct species-the FALL CANKER WORM and the Spring Canker Worir. The different stages of the former pest are illustrated in Fig. 4, page I 4, where a resumé of its life-history will be found.

The Tent Caterpillar is another insect that is often extremely destructive to apple foliage. This is the creature that constructs the silken tent-like nests so often seen in spring on the branching limbs of apple and wild cherry trees. Its life-history is as follows : The eggs are deposited during July in compact masses of 200 or 300 each upon the twigs (Plate II., $e, c$ ), and are covered with varnish $(e)$. The following spring they hatch into caterpillars that feed upon the tender foliage and make a silken tent in a fork of the twigs. They become full grown in about six weeks $(a, b$,$) .$ They then leave the tree and crawl about in search of a suitable shelter to pupate in. Having found thisbeneath a board, or in the cracks of a fence-they spin an oval, silken cocoon $(d)$, yellow when completed, within which they change to pupx. In two or three weeks the reddish-brown moths $(f)$ come forth. These 
deposit the clusters of eggs, after which they soon die. There are a number of other caterpillars which feed upon apple foliage, notably several species of LEAFROLLERS, the YELLOW-NECKED CATER P I L LAR, the LE A F - CRUMPLER, the LEAF-SKELETONIZER, etc., all of which are treat ${ }^{-}$ ed of in the author's Insects and Insecticides, and all of which can be destroyed by spraying. $\mathrm{Th}$ e APPLE-TREe FleABEETLE (Fig. I 5) is a small shin-

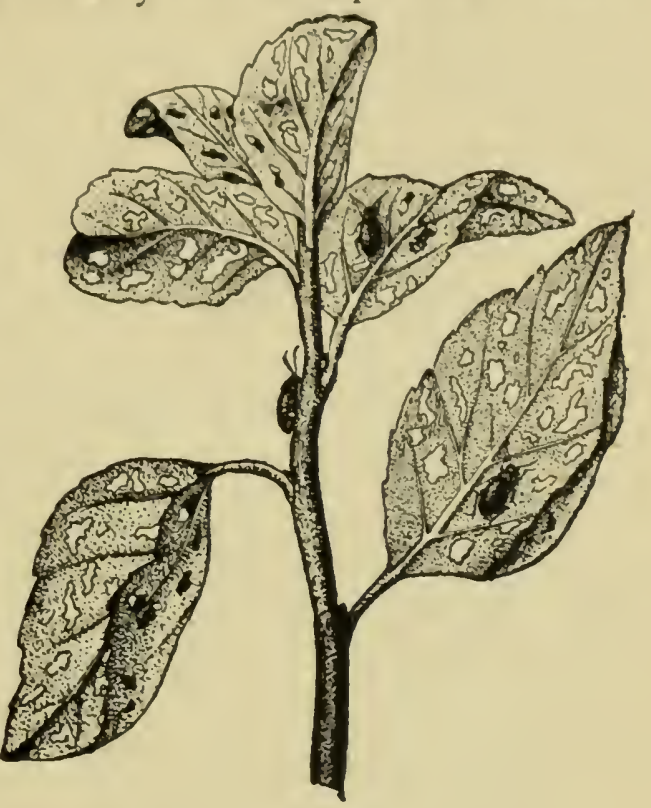
Fig. 15. Apple Tree Flea-Beetle. ing beetle that is often destructive in the West. Spraying with the arsenites checks it.

REMEDIES.-As a rule, none of these insects will be injurious in an orchard that is regularly sprayed for the Codling Moth, because such spraying destroys them as well. It occasionally becomes necessary in unsprayed orchards infested by Canker Worms to spray very early, even before the trees blossom, to destroy the young worms. In case of serious outbreaks of leaf-eating caterpillars it is sometimes well to increase the proportion of poison, but it should never be less than one 
pound to 125 gallons of water, and even then lime should be added.

The Apple Aphis.-During spring the leaves and tender twigs of apple are often covered with small green lice or aphides. These are the Apple Aphis. They injure the trees by sucking the sap through their

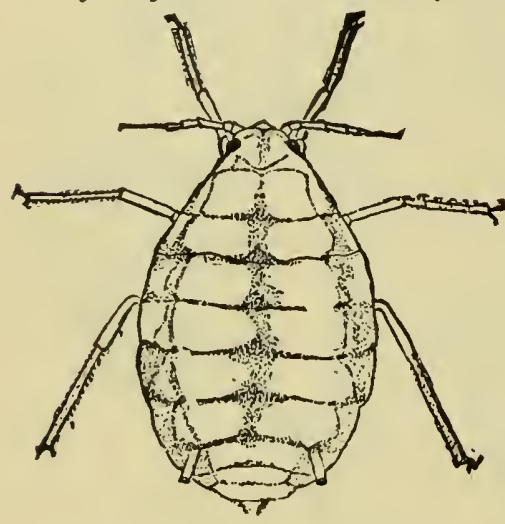

FIG. I6. Apple Aphis. Much magnified. tiny beaks. The lice hatch from eggs in spring as soon as the leaf-buds begin to expand, and they increase with marvelous rapidity, so that almost as fast as the leaves develop there are colonies of the plant-lice to occupy them. They breed on apple until July, when they largely leave the trees, and migrate apparently to the roots of grasses. Here they continue breeding until autumn, when they return to apple, and the winged females establish colonies of the wingless, egg-laying form upon the leaves. The small, oval eggs are now laid on the twigs and buds, and the cycle for the year is complete.

REMEDY.- Spray with kerosene emulsion as soon in spring as the eggs hatch-usually before the leaves expand.

The opening buds of apples are sometimes seriously injured by the larva of the Eve-SPOTted Bun-Moth. This is a small cylindrical worm, three fourths of an 
inch long, which lives in a rude case made by fastening particles of dead leaves together with silk. It attacks the buds, blossoms, and newly-formed fruit as well as the leaves, and becomes full-grown early in Junc. The larve then pupate within their cases, and in a few weeks emerge as small gray moths, with two little eyespots on each of the front wings.

REMEDIES.--This is a difficult pest to contend with, and the most promising remedy is to spray early, when the buds are opening, with a combination of Paris green and the Bordeaux mixture, continuing the treatment later as recommended below.

\section{Fungous Enemies}

Probably no fungous disease of fruit is more familiar to the general public than the APple SCAB, or, as it is occasionally called, the Black Spot. This is due to a fungus which produces the well-known scabby spots upon the fruit, and also attacks the leaves and green shoots. It first appears on the leaves in the shape of smoky, greenish spots, more or less circular in outline. These gradually enlarge, and frequently several of them run together, so as to form good-sized blotches; and as they grow older their color darkens, finally becoming almost black. The upper surface of the leaf is generally the one infested. Immense numbers of spores are produced on these blackened spots of the leaf and fruit, forming most abundantly during cool, wet weather. By means of these spores the fungus reproduces itself; they are carried from leaf to leaf 
and fruit to fruit by wind and rain, and germinating, start the disease in a new situation. The spores pass the winter on stored fruit, fallen leaves, etc., and in spring start the disease again.

REMEDIES.-In spring, just before the leaf-buds open, spray thoroughly with the dilute Bordeaux mixture (75-gallon formula); repeat the application a little later just before the blossoms open, adding Paris green if the bud-worm is present; spray for the third time just after the blossoms have fallen, adding four ounces of London purple or Paris green to every barrel of Bordeaux mixture, in order to destroy the codling moth larvæ, and other insects as well as the scab; ten days after this third application, spray again with the combination of Bordeaux mixture and London purple or Paris green. Do not apply the Bordeaux mixture late in the season; it is liable to injure the skin of the apple by giving it a rough and russet appearance. Fruit sprayed in this way is much larger and finer than that not sprayed.

In southerly latitudes, orchardists are greatly troubled by another fungous disease, the APPLE ROT, which attacks the maturing fruit, rotting it and causing serious losses. Experiments in Kentucky by Professor Garman have shown that this disease may be prevented by treatment with Bordeaux mixture similar to that indicated above. 


\section{THE PLUM}

\section{Insect Enemies of the Fruit}

The Plum Curculio is by far the worst insect foe of the plum. It is the cause of most of the common worminess and premature dropping of the fruit. An account of its life-history will be found on page 12 .

REMEDIES.-The evidence in hand indicates that spraying with the arsenites is the best way to fight this pest, especially in orchards of considerable size. This remedy acts by destroying the adult beetles rather than the larva. The trees should be sprayed three or four times, at intervals of ten days or two weeks, beginning, as soon as the blossoms have fallen, with Paris green mixed with water in the proportion of three ounces to forty or fifty gallons. These sprayings will also destroy certain other insects affecting the fruit, although it is generally supposed that they will not kill the Plum Gouger-an insect related to the curculios - which is very injurious in some of the IVestern States. The best way will probably be to combine Paris green or London purple with the Bordeaux mixture as described under the next heading, and so fight both the insect and fungous pests at the same time. This is especially desirable because the arsenites alone are liable to injure the foliage when a series of applications are made. 


\section{Fungous Enemies}

The Brown Rot of Stone-Fruits is the most serious enemy under this heading. Fruit affected by this disease turns brown and rots, and generally develops on the skin, a velvety or powdery brown coating. This coating consists of a great number of minute spores fastened together, end to end. If one of these velvety masses be shaken over a glass slide and the slide then put under a microscope, it will be seen that a great many of the spores have separated and fallen off. When one of these spores lights upon a green plum, peach, or cherry, and a drop of water happens to form over it, it sends out a germinating tube which penetrates the skin of the fruit, and once inside develops a mass of mycelium, disorganizing the tissues and causing rot. Then this mycelium develops a new mass of spores, and thus the fungus propagates itself. After the development of the spores, the plums or peaches dry up and hang on the limbs until the following season, when they start the disease again. Even the blossoms are often attacked.

The first step towards preventing this disease is to pick off and burn the dry and mummied plums that hang on the trees over winter. These carry the disease through cold weather and start it again in the spring. Rotting plums during the ripening period should also be promptly removed.

During summer the leaves of plums and cherries are often injured by the PLuM LFAF-BLight or SHot-hole 
Funcus, which first appears in the shape of small dark purple spots scattered over the leaf. These spots soon become brown, and the leaf tissue composing them is dead. 'This dead tissue generally drops out of the leaf in course of a few weeks, leaving circular holes resembling shot holes. A microscopic examination of the under surface of these spots generally reveals one or more blackish points consisting of the fruiting spores of the fungus. It is by means of these that it passes the winter, and propagates itself. The affected leaves often turn yellow and fall off.

Remedies. - It has been definitely proven that these diseases can largely be prevented by spraying. A treatment similar to that recom-

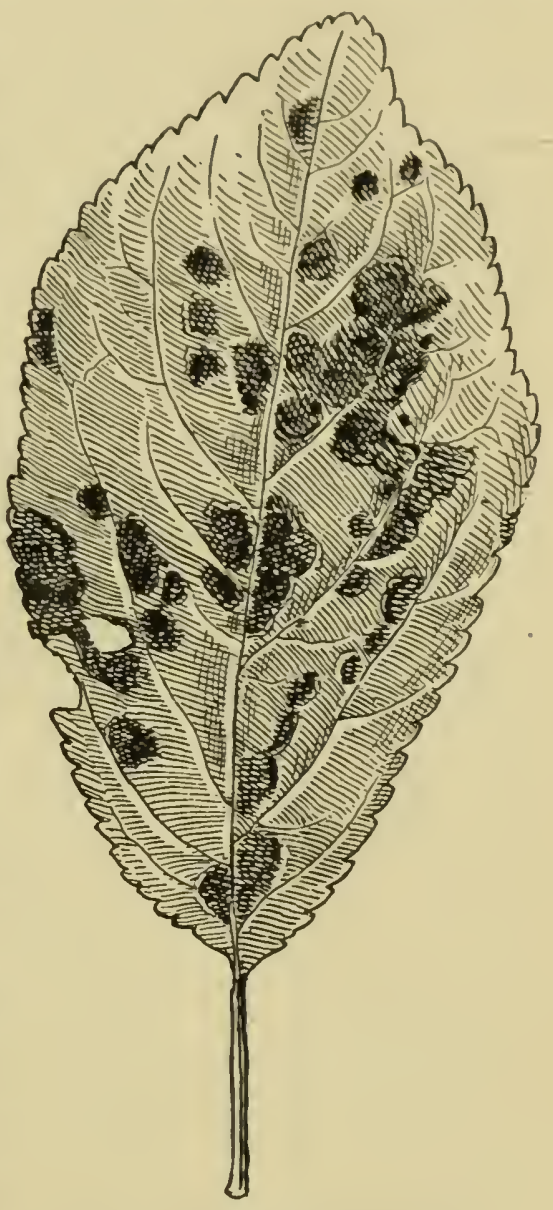

FIG. 17. Diseased Plum Leaf. mended for apple-scab, one spraying with dilute Bordeaux mixture before blossoms open, then three spray- 
ings with Bordeaux mixture and London purple after the fruit forms, is the most promising treatment for both insect and fungous pests. It may be necessary to make one or two late sprayings with a carbonate of copper solution in case rot sets in. The mummied plums should be picked off and burned in the winter; and an early spring spraying with simple solution of copper sulphate, applied before the buds swell, is very beneficial.

During recent years trouble has been experienced in some localities because of the FRUIT-BARK BORER, an insect that burrows channels beneath the bark. There is some evidence to show that spraying the trunks and larger branches with the combination of Bordeaux mixture and Paris green will prevent such injury. The first application should be made early in the spring, and others follow at occasional intervals until July. 


\section{THE PEACH}

\section{Insect Enemies of the Fruit}

The Plum Curculio, whose life-history has already been treated of on page $\mathrm{I} 2$, breeds in peaches, as well as in plums, cherries, apples, and other fruits. It is especially liable to injure peaches when there is a failure of the apple crop. It is more difficult to prevent its injuries on this crop than on the apple or plum, because ordinarily it is impracticable to jar peach trees, and their foliage is so easily injured by the arsenites that spraying must be done with great caution. In using either Paris green or London purple on this fruit, lime should always be added to prevent injury to the foliage, or the arsenite may be used in combination with Bordeaux mixture.

\section{Insect Enemies of the Foliage}

Peach foliage is occasionally attacked by the REDLEGGED FLEA-BEETLE, a small jumping beetle which can be destroyed by spraying with the Paris green and lime mixture.

There are two distinct species of aphides or plantlice attacking the peach. One is called the PEACH Aphis, and the other the Black PEach Aphis. The latter infests the roots and twigs as well as the leaves. 
Both species are soft, blackish little creatures that crowd together on the foliage and twigs. During the summer they reproduce viviparously. Spraying with kerosene emulsion, fish-oil soap, or tobacco decoction, as early as possible after the pests appear in spring, is the best remedy. The time to reach them easiest is when the buds are swelling, and the newly hatched lice are on the bare twigs.

\section{Fungous Enemies}

The Brown Rot, already discussed as a plum disease (page 64), is often extremely destructive to peaches. It sometimes attacks the trees early in spring, causing an injury to the twigs and blossoms called blight, and again infests the fruit up to the time of ripening, and even after it is gathered.

The most promising remedial measures are those of picking off all the dry peaches hanging on the tree during winter, and then spraying early in the spring, before the buds begin to swell, with a dilute Bordeaux mixture, which may often be repeated to advantage just before the blossoms open. Then after the blossom petals have fallen spray twice with an interval of two weeks between. Peach foliage is very easily injured, and care should be taken in spraying it. There is reason to hope that these early sprayings will also prevent the troublesome Peach Leaf Curl. 


\section{THE PEAR}

\section{Insect Enemies of the Fruit}

The fruit of the pear is attacked by both the CoDling Moth and Plum Curculio. The injury of the latter causes it to be knotty, gnarly, and one-sided, ruining it for market purposes. Fortunately the injuries of both may be prevented by two or three sprayings with Paris green mixed with water at the rate of one ounce to twelve gallons. The first application should be made as soon as the petals have fallen, and the others at intervals of ten days or two weeks. Add lime to the mixture, unless the Bordeaux mixture combination is used.

\section{Insect Enemies of the Foliage}

The leaves of pear, cherry, quince, and plum trees are frequently attacked during June and July by a

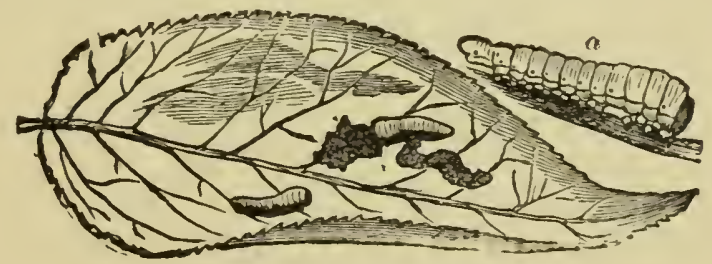

FIG. I8. Pear-tree Slug.

greenish-black, slimy slug that eats the upper surface. This is the Pear-tree Slug. The adult is a four- 
winged black fly that deposits eggs in the leaf early in the summer. The eggs soon hatch into larvæ which become full-grown (Fig. I8) in four or five weeks. They then shed their slimy skin, appearing in a clean yellow one, and soon descend to the ground which they enter two or three inches, and pupate in oval cocoons. A fortnight later the fly emerges. These larva are easily destroyed by spraying with hellebore or the arsenites.

In a number of the Eastern states a small insect, the PEar PSylla, has recently caused serious damage by sucking the sap from the leaves. The insects pass the winter as adults, and in early spring deposit eggs on the bark especially about the buds. About a fortnight later they hatch into young-called nymphs-which suck the sap from the petioles of the leaves and stems of the young fruit. Fig. 19. Pear Psylla. Recent experiments have shown that Magnified. the young nymphs may easily be destroyed by spraying with kerosene emulsion.

\section{Fungous Enemies}

The Pear Leaf-Blight is the most destructive fungous disease of the pear for which the sprayingmachine may be successfully used. It occurs both on the foliage and fruit; on the former causing small, 
discolored spots, and on the latter producing a very injurious cracking of the skin. It appears soon after the leaves develop, in the shape of small dull-red spots on the upper surface; then the lower surface becomes spotted, and the spots gradually change to a dark brown color with black specks in the middle. The affected portions enlarge, and finally the whole leaf becomes diseased and falls off (Plate $\mathrm{r}$ ). The red spots also appear upon the fruit; the skin becomes much roughened and finally splits open in long cracks.

Remedies.-Spray twice with the 50 or 60 gallon formula of the Bordeaux mixture, applying first about one month after the blossoms fall, and again a month later. If more than two applications of the Bordeaux mixture are made after blooming, there is danger of giving the fruit a russet appearance. In case of early pears only one application should be made after blooming. If late applications are made the copper carbonate or some similar fungicide should be used. The effect of treatment with the Bordeaux mixture, as shown in one of Mr. Galloway's experiments, is illustrated in Plate I (Frontispiece).

By adding Paris green to the Bordeaux mixture, both insects and fungous injuries will be prevented.

The PEAR SCAB is a disease very similar to apple scab, the fungus, in fact, being believed by many botanists to be the same species. At any rate, the chief points in the life-history and remedial treatment are the same as for the apple disease. Spray with dilute Bordeaux mixture, first as soon as fruit buds open 
second just before blooming; third as soon as blossoms fall, and fourth about three weeks later.

Care should be taken not to apply the Bordeaux mixture too late in the season. Early varieties should have but one spraying with this mixture after the fruit "sets," and late varieties but two. Where additional applications are needed, use the copper carbonate solution.

Pear trees, especially older ones in southern latitudes, as well as apple trees, are often largely covered with Lichens of various kinds. Recent experiments by Mr. M. B. Waite show that these are destroyed by spraying with the Bordeaux mixture.

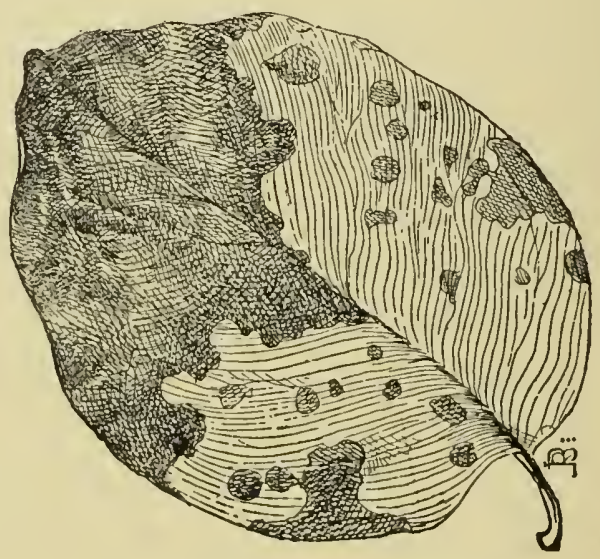

FIG. 20. Quince Leaf Blight.

The Quince is subject to the leaf-blight above discussed as a pear pest, and to various other diseases. As a general rule, it should receive treatment similar to that given the pear, although a larger number of sprayings seem to be necessary. 


\section{THE CHERRY}

\section{Insect Enemies of the Fruit}

The Plum Curculio, which has already been discussed under The Plum (p. 63), is also exceedingly injurious to cherries. The latter, however, usually do not fall off when infested by the curculio larvæ, but remain on the tree until the fruit ripens. The remedial measures suggested in connection with the plum are equally applicable to this fruit.

Some varieties of cherries, especially the early ones, are very susceptible to injury by arsenites, and London purple should not be used upon them unless lime is added to the solution. If Paris green alone is used apply at the rate of 2 ounces to 50 gallons of water. Do not spray early varieties more than twice, or late ones more than three times.

\section{Insect Enemies of the Foliage}

The twigs and under surface of the leaves of cherry trees are frequently thickly infested during May and June by small, shining black plant-lice, that suck out the sap and deform the leaves. This insect is the CHERRY ApHis. It winters over on the twigs in the egg state. Early in spring the eggs hatch into young aphides that insert their tiny sap-sucking beaks into the unfolding 
leaves. In a week or ten days they become full-grown, and give birth to young lice, which soon develop and repeat the process. In this way they increase with marvelous rapidity. Late in June or early in July they leave the cherry, migrating to some other plant. Here they develop through the summer, and in autumn a winged brood again appears and migrates back to the cherry. These migrants give birth to young that develop into egg-laying females, which deposit small, oval, shining black eggs upon the twigs.

REMEDY.- Spray with kerosene emulsion. This can be done most easily and effectively early in spring, when the newly-hatched lice are crowded upon the bursting buds.

The Pear-Tree Slug, which has already been discussed as a pear insect, is probably as destructive to cherry foliage as to that of the pear. Its life-history on the two fruits is sinilar, and the remedies are the same in both cases.

\section{Fungous Enemies}

The cherry is subject to much the same fungous diseases that the plum is. The leaves are attacked by the Cherry-leaf Blight, and the fruit by Brown Rot. The remedial measures already suggested for these diseases are applicable here. 


\section{THE ORANGE AND OTHER CITROUS FRUITS}

\section{Insect Enemies}

The scale insects are among the most destructive insect enemies of citrous fruits. Recent researches have shown the "resin washes" to be satisfactory remedies to use against them, and Dr. C. V. Riley has published the following instructions for their preparation and use :

The Resin Washes.- "These insecticides act by contact, and also in the case of scale-insects, by forming an impervious coating which effectually smothers the insects treated. These resin washes vary in efficacy, according to the insect treated. Experience has shown that the best formula for the red scale (Aspidiotus aurantii Maskell) and its yellow variety ( $A$. citrinus Coquillet) is as follows :

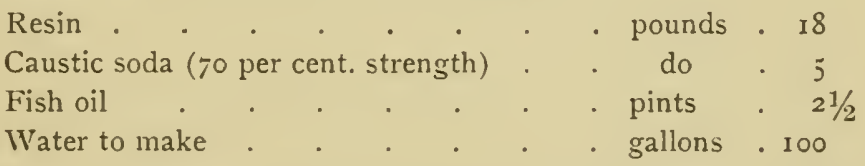

"The necessary ingredients are placed in a kettle, and a sufficient quantity of cold water is added to cover them. They are then boiled until dissolved, being occasionally stirred in the meantime, and after the materials are dissolved the boiling should be con- 
tinued for about an hour, and a considerable degree of heat should be employed, so as to keep the preparation in a brisk state of ebullition, cold water being added in small quantities whenever there are indications of the preparation boiling over. Too much cold water, however, should not be added at one time, or the boiling process will be arrested and thereby delayed, but by a little practice the operator will learn how much water to add so as to keep the preparation boiling actively. Stirring the preparation is quite necessary during this stage of the work. When boiled sufficiently it will assimilate perfectly with water, and should then be diluted with the proper quantity of cold water, adding it slowly at first and stirring occasionally during the process. The undiluted preparation is pale yellowish in color, but by the addition of water it becomes a very dark brown. Before being sprayed on the trees it should be strained through a fine wire sieve, or through a piece of Swiss muslin, and this is usually accomplished when pouring the liquid into the spraying tank, by means of a strainer placed over the opening through which the preparation is introduced into the tank.

"The preparing of this compound will be greatly accelerated if the resin and caustic soda are first pulverized before being placed in the boiler, but this is quite a difficult task to perform. Both of these substances are put up in large cakes for the wholesale trade, the resin being in wooden barrels, each barrel containing a single cake, weighing about 375 pounds, 
while the caustic soda is put up in iron drums containing a single cake each, weighing about Soo pounds. The soda is the most difficult to dissolve, but this could doubtless be obviated by first dissolving it in cold water and then using the solution as required. This insecticide may be applied at any time during the growing season.

"A stronger wash is required for the San José scale (Aspidiotus perniciosus Comstock), and the following formula gives the best results :

Resin

Caustic soda (jo per cent) .

$\begin{array}{cc}\text { pounds } & \cdot 30 \\ \text { do } & \cdot \\ \text { pints } & \cdot 4^{1 / 2} \\ \text { gallons } & \cdot 100\end{array}$

"Place all the ingredients in a kettle and cover with water to a depth of four or five inches; boil briskly for about two hours, or until the compound can be perfectly dissolved with water. When this stage is reached the kettle should be filled up with water, care being taken not to chill the wash by adding large quantities of cold water at once. It may be thus diluted to about 40 gallons, the additional water being added from time to time as it is used.

"This preparation should only be applied during winter or during the dormant period; applied in the growing season, it will cause the loss of foliage and fruit."

Apply by means of a coarse spray. 



\section{PART II}

SPRAYING SMALL FRUITS AND NURSERY STOCK 


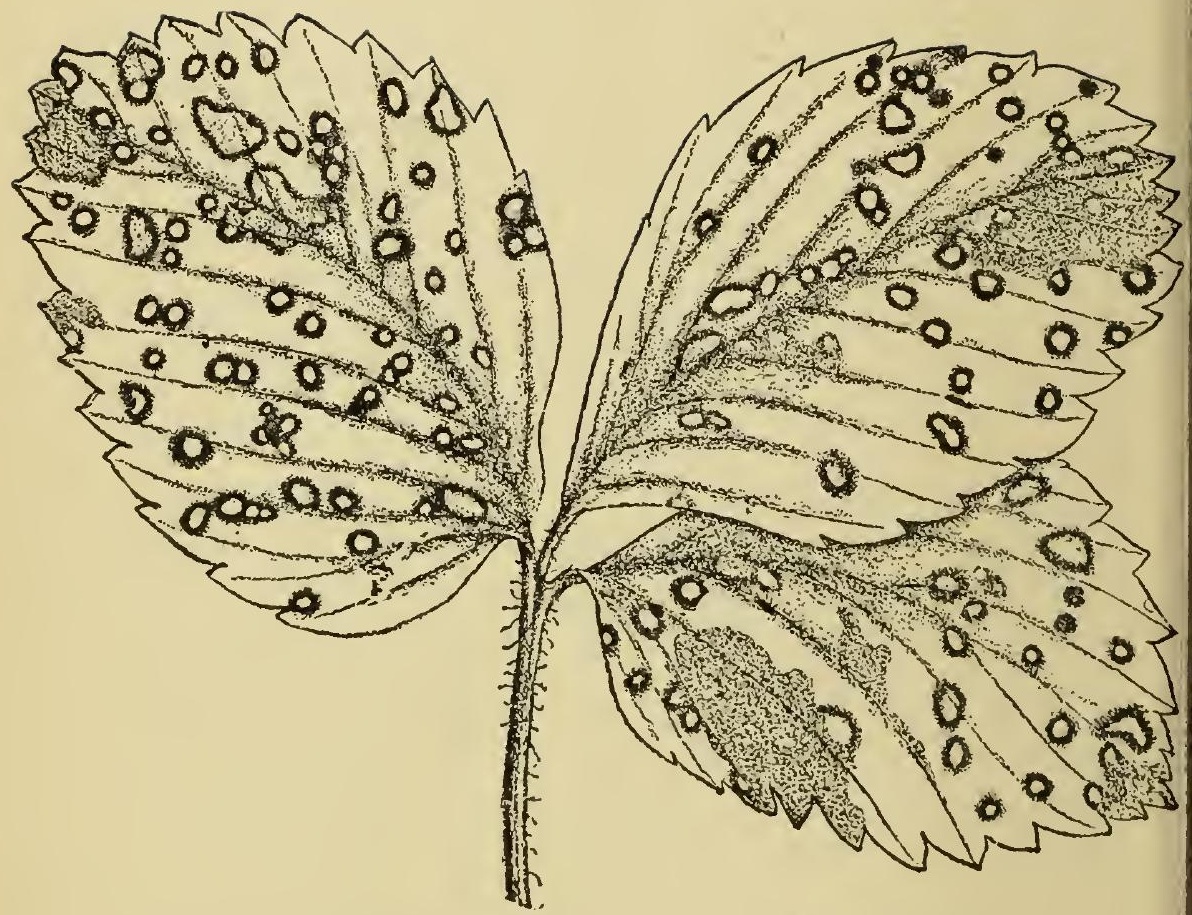

Plate III.-Strawierry Lieaf Affected with Blight. 


\section{THE STRAWBERRY}

\section{Insect Enemies of the Foliage}

The transformations of the StrawberRy Slug have been well represented by Dr. Riley in Fig. $2 \mathbf{I}$. The four-winged fly (3) appears in spring, and deposits its eggs within the tissues of the leaf or stem. The larva feed upon the leaf, gnawing small, circular holes at

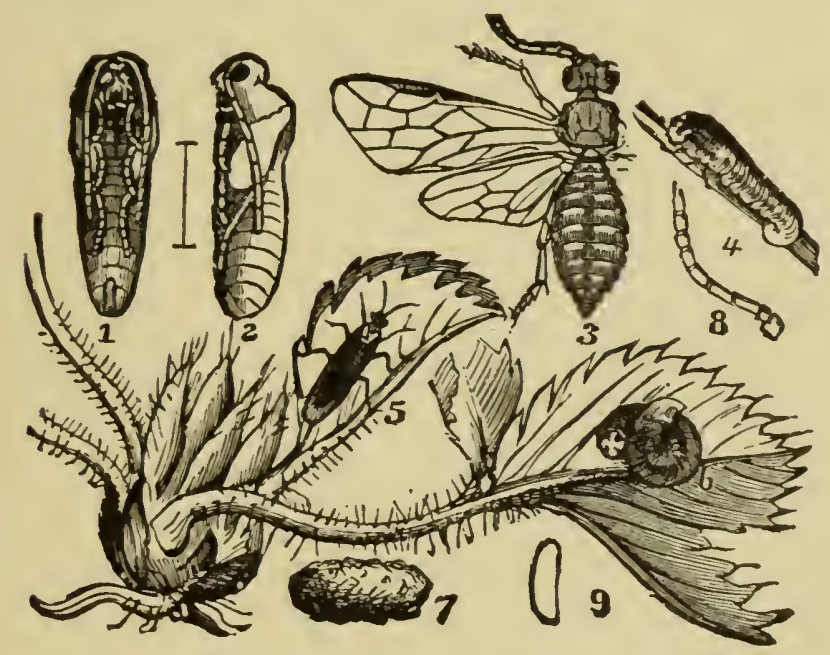

FIG. 2I. Strawberry Slug: I, 2, pupa; 3, 3, fly; 4, 6, larvæ; 7 , cocoon; 8, antenna ; 9 , egg, magnified.

first. They develop in five or six weeks into pale green worms $(4,6)$ about three fourths of an inch long. The larva now go slightly beneath the surface, and 
there they form cocoons ( 7$)$ within which they change to the pupa state $(1,2)$, and later emerge as flies. In the southern states there are two broods each season, while at the North there appears to be but one.

REMEDIES.-On the non-fruiting plantations it may be destroyed by spraying or dusting with hellebore or Paris green. On fruiting plantations this method may be used in localities where a second brood of larvæ appears after the fruit is gathered. Pyrethrum or insect-powder may be used in such cases on the first brood.

The Strawberry Leaf-Roller is a small, brownish caterpillar that folds the leaflets of the strawberry by bringing the upper surfaces together and fastening them by silken cords (Fig. 22), and feeds upon their substance till they look brown and scorched. It hatches from eggs laid in spring upon the strawberry plants by a small reddish-brown moth. The larva attains its full growth in June, when it is nearly half an inch long, of a brown or greenish color, with a shining yellowish-brown head. It pupates within the rolled leaf, and about midsummer energes as a moth. These moths deposit eggs for a second brood, that feed upon the leaves late in summer, changing to pupæ early in autumn; and, passing the winter in that condition, emerge as moths the following spring.

REMEDIES.-Mow the field soon after the crop is gathered, and after leaving it a day or two to become dry, burn it over. This destroys the leaf-rollers as well as several other kinds of insects, and the spores of fun- 
gous discases. Scatter a little straw over the field where the leaves are not thick enough to burn well. The plants will not be damaged, but will soon send up a new lot of leaves that will grow rapidly, and be free from insect and fungous attack. If for any reason this

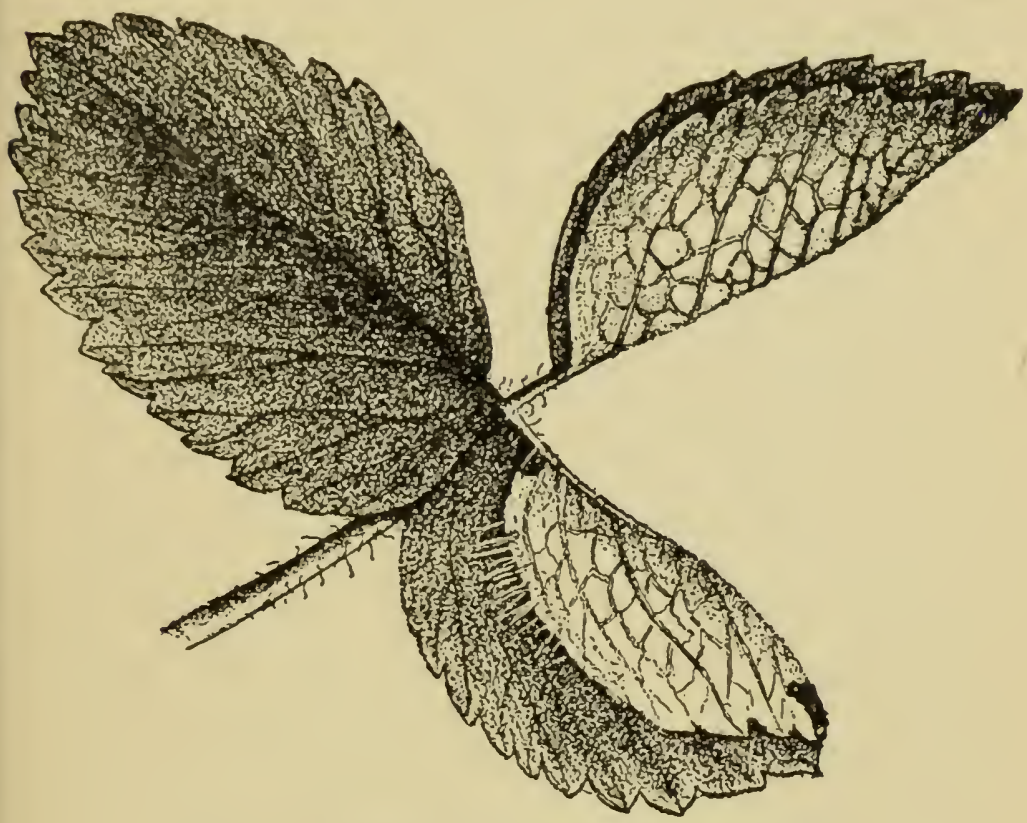

FIG. 22. Strawberry leaf folded by Leaf-roller.

method is not desirable, the insects of the second brood may be destroyed by spraying or dusting the plants in August with some poisonous insecticide.

The foliage of strawberries is also attacked by certain Strawberry Leaf-beetles, the parents of the STRAWBERRY ROOT-WORMS. On young non-fruiting plantations, and on fruiting plantations after the crop 
is gathered, these insects may be destroyed by spraying with Paris green or London purple.

\section{Fungous Enemies}

The STrawberry Leaf-Blight is the most destructive fungous enemy of this fruit., "The presence of the blight fungus," says Professor H. Garman, "is first marked by the appearance of small brown spots, varying from one sixteenth to one eighth inch. As they become abundant the spots fuse, forming extensive brown areas, and finally occupy the whole leaf. Eventually most spots show at the upper side of the leaves a rim of dull purple of varying width. Towards fall this change in the color of the leaf is more prevalent. If one of the spots be cut through with a pair of fine scissors, the leaf will be found, at the point where the spot is formed, much thinner than elsewhere, because of the killing and drying out of its substance. Examined under a microscope, the fungus may now be found to have pushed through the tissues of the leaf, and to have formed all over the brown central region of the spot, but most abundantly at its margins, small whitish tufts, looking like microscopic shrubs. These are the fruiting parts of the parasite, and are made up of numerous threads, each bearing at its summit a long jointed spore. As these latter ripen they are set free, and are scattered upon fresh leaves by winds and rains, to germinate there, push into the leaves, and form new spots." The fungus is propagated by these long spores throughout the summer, but in autumn the 
threads of mycelium "form solid tissue-like masses in the dead parts of the spots," which finally appear at the surface as small black dots. By means of these dots or nodules the fungus passes the winter. A leaf affected by this disease is represented in Plate III.

RExiEDIES.-During July and August spray with Bordeaux mixture or ammonical solution of copper carbonate, at intervals of two weeks. Try mowing and burning foliage soon after the fruit is gathered, and then spray as just directed. Mowing and burning at this time, without subsequent spraying, is believed to increase rather than diminish the blight, at least southward; but mowing and burning may often be done to good advantage, at least in southerly latitudes, in autumn. 


\section{THE CURRANT AND GOOSEBERRY}

\section{Insect Enemies of the Foliage}

The worst enemy of currant foliage is the IMPORTED CURrant Worm. Early in spring four-winged flies deposit rows of small, whitish, glassy eggs on the principal veins of the under sides of the lower leaves.

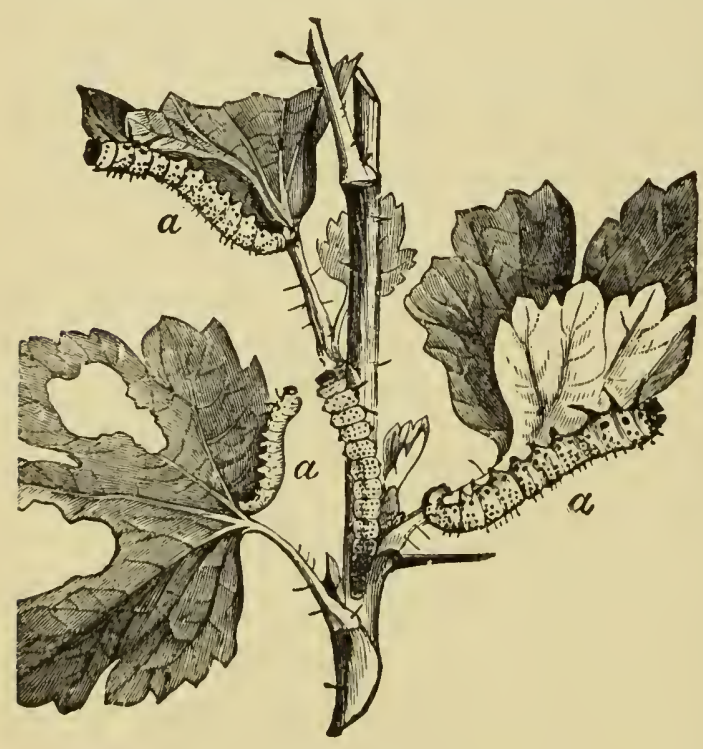

FIG. 23. Currant Worms Eating Leaves.

In about ten days the small worms hatch and eat circular holes in the leaf. At first these larvæ are whitish in color; they soon change to green, then to green with numerous black spots, and at last back again to a plain light green, with a tinge of yellow at the sides and ends (Fig. 23). The full-grown larva spin tough brown cocoons, beneath the leaves and rubbish on the ground, within which they change to pupx. From 
these cocoons the flies emerge early in summer, to lay eggs for a second brood, which passes the winter within the cocoons.

RExEDY.-Spray with hellebore-one ounce to three gallons water-as soon as holes appear in lower leaves. Spray again ten days later.

Currant leaves are often specked with white by the Currant Leaf-hopper, a small, pale-green insect, onetenth inch long, that lives on the under side and sucks the sap. The chief damage is done by the first brood,

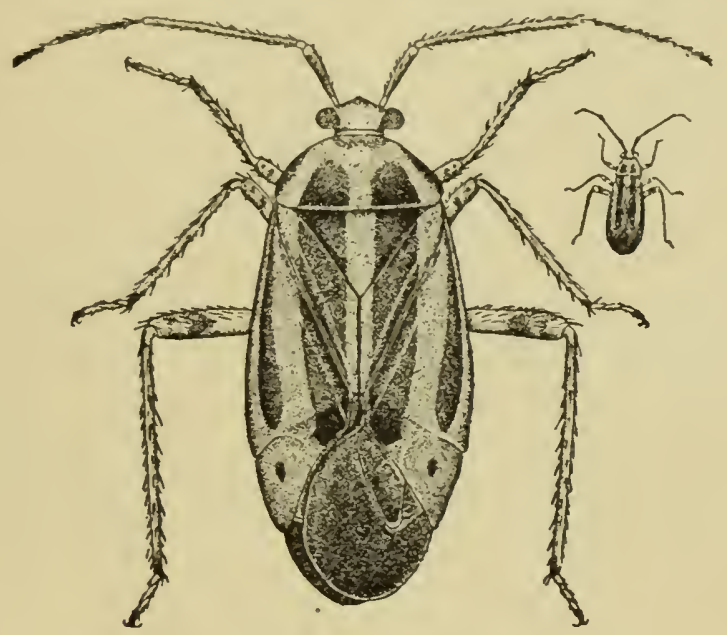

FIG. 24. Four-lined Leaf-Bug.

the insects leaving the bushes in early summer, probably preferring at this time the more succulent foliage of other plants.

REMEDIES.-Spray forcibly with pyrethrum or insectpowder-one ounce to three gallons water; or with tobacco decoction. Begin early, before the insects get their wings. 
The foliage on the tips of currant and gooseberry stems is often blighted in spring by the FouR-LINED LEAF-BUG, a small insect represented natural size and magnified in Fig. 2 $\mathbf{I}$. The young appear early in spring and suck the sap from the unfolding leaves, causing them to wilt and appear blighted as in Fig. 25.

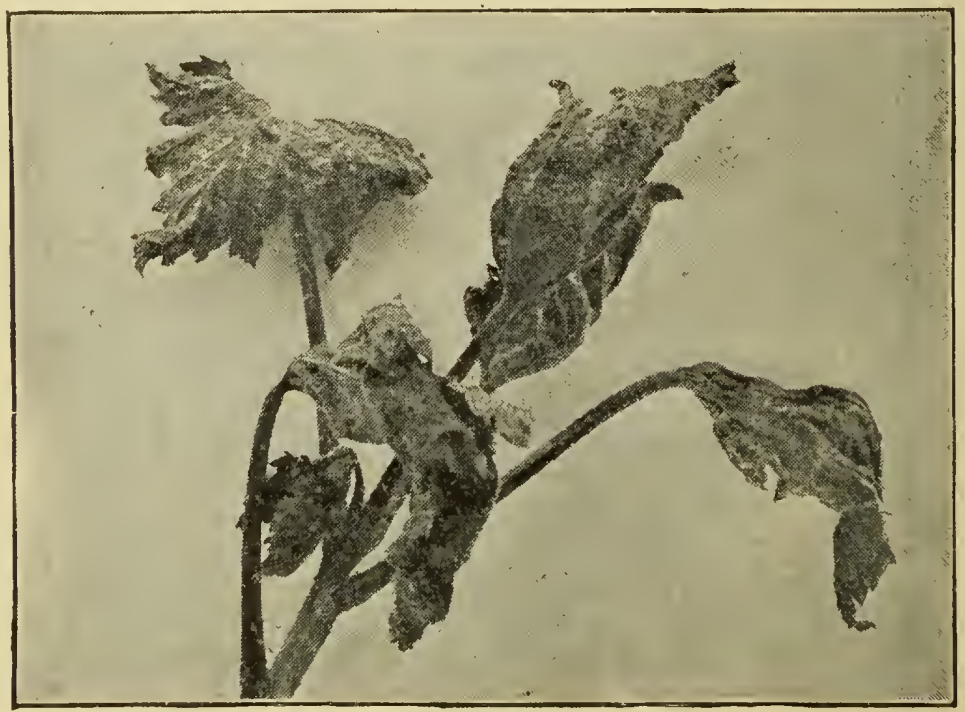

FIG. 25. Currant leaves killed by the insect.

Mr. M. V. Slingerland, who has studied this pest thoroughly, finds that its eggs are laid in currant stems and pass the winter there. Consequently pruning the stems between September and April-burning the portions cut off-will be a partial preventive; and spraying with kerosene emulsion early in the season, when the insects are immature, will destroy many of them. 
The only other remedy suggested is that of jarring the pests into pans containing kerosene and water.

The Currant Aphis is a small, yellowish insect found on the under sides of curled and blistered currant leaves early in summer. Such leaves are generally tinged with reddish above. The insects apparently migrate to some other plant during the summer, returning to the currant in autumn, and depositing small, black eggs upon the stems, especially about the buds.

REMEDIES.-On account of the deformed leaves, these insects are difficult to reach with insecticides. Spraying with kerosene emulsion quite early in the season, before the foliage has expanded, is the best remedy.

\section{Fungous Enemies}

For many years it has been impracticable to grow foreign varieties of gooseberries in the United States, on account of the attacks of the Gooseberry Mildew. According to Dr. B. D. Halsted, this mildew "first makes its appearance upon the young half-grown leaves, and the unfolding terminal bud of the shoot. In its early stage it has a cobwebby appearance, which soon becomes white and powdery from the development of the light summer spores. Soon after this, thin patches of the same character may be found upon the forming berries. Usually one side is more attacked than the other, and as the berry continues to grow it becomes one-sided or curved, because the 
fungus retards the development upon the infested side. If the berry is entirely covered, its further development is generally checked. Later in the season the leaves, and especially their petioles, and the young stems bearing them, turn to a rusty-brown color, and become thickly coated with the fungus. The berries at the same time are covered with brown patches of mycelium, which may readily be peeled off from the smooth skin of the fruit."

REMEDIES.- Spray with a solution of potassium sulphide (liver of sulphur) at the rate of one half ounce to one gallon water. Begin as soon as the leaves commence unfolding, and repeat the application at intervals of eighteen to twenty days. The sulphide dissolves more readily in hot than in cold water. This treatment has proven entirely efficacious for a number of years at the New York experiment station. Early in the season the Bordeaux mixture may be used instead of the sulphide if more convenient, and it is desirable to spray with Bordeaux mixture after the fruit is gathered, to prevent the various spot-diseases, that often cause the foliage to drop off late in summer. 


\section{THE GRAPE}

\section{Insect Enemies of the Foliage}

The Grape-vine Flea-beetle is a small, steel-blue beetle that is often very destructive to grape-vines. As soon in spring as the buds swell the beetles attack them, and continue feeding for three or four weeks, during the latter part of the time depositing small, orange-yellow eggs in clusters on the under sides of the leaves. The eggs hatch into small, dark-colored larvæ that gnaw irregular holes in the leaves. When fully grown (three or four weeks after hatching), they are about 3-10 inch long, brown in color, with six legs, and four or five black dots on the back of each ring or segment of the body. The head is black, and there are numerous hairs on the body. They now enter the soil, pupate, and a few weeks later emerge as beetles, which feed upon the foliage and lay eggs for a second brood of larvæ.

Renedy.-Spray with Paris green or London purple (having a little lime added) at a strength of three or four ounces to fifty gallons water, as soon as beetles appear in spring; or else with the arsenited Bordeaux mixture.

\section{Fungous Enemies}

The BLACK Rot of grapes has long been recognized as the most destructive fungous disease which Ameri- 
can vineyardists have encountered. Generally the fungus first appears in the shape of round, reddishbrown spots on the grape leaves. About a fortnight later the attack on the berries will be noticed. The effect on these is most disastrous; as the mycelium develops among the cells of the fruit the berries stop growing, and finally become disorganized, shapeless, juiceless masses, shriveled to one half their proper size and fit only to develop the spores of the destroying fungus. And they do produce these spores, which are massed together in little black pustules scattered over the surface of the withered skin.

This Black Rot fungus is most destructive in southern latitudes. As far north as northern Ohio and western New York it is much less virulent than in Tennessee or the Carolinas. Like most fungous diseases it develops with greatest rapidity during damp, hot weather, or when nights with heavy dews alternate with hot days.

REMEDIES.-Spray with the Bordeaux mixture, four to seven times, making the first application just before the buds swell; the second, when the leaves are one third grown; the third, just before the blossoms open, repeating the later sprayings at intervals of about fifteen days. In case Bordeaux mixture is used, substitute the ammonical solution of copper carbonate for the last one or two sprayings, to avoid spotting the fruit.

An account of the development of the Downy Mildew or Brown RoT of grapes has already been given 
in the Introduction (pp. $16-18$ ). This disease has been, in years past, extremely destructive over a wide area; and it attacks disastrously both the foliage and fruit. In southern latitudes it is said to be most injurious to the former.

Remedies. - The Bordeaux mixture is a practical and efficient preventive of this disease. Spray first a week or ten days before the vines blossom; second, as soon as the berries are well set; and third, about three weeks later? In the very wet seasons it may be desirable to spray a fourth time, but this is seldom done. Eau Celeste is sometimes used for this disease, but the Bordeaux mixture seems preferable. 


\section{THE RASPBERRY}

\section{Insect Enemies of the Foliage}

The Raspberry Slug is the larva of a four-winged black fly with a reddish abdomen, which deposits eggs during spring in the leaf. They hatch into small, whitish worms that feed upon the tender foliage, and in a few weeks become full-grown. They are then $3 / 4$ inch long, of a dark green color, and have the body thickly covered with spinose tubercles. The slugs now descend to the ground, and construct rather firm cocoons slightly beneath the soil surface. They remain in these cocoons until spring, when they come forth as flies.

REMEDy.-Spray the infested bushes with powdered hellebore. Use from one half to one pound of hellebore to fifty gallons of water, and apply forcibly, as soon as the worms appear.

\section{Fungous Enemies}

The Anthracnose or CANE-RUST of the raspberry is one of the most vexatious diseases with which the fruit-grower has to contend. Infested canes are characterized by having numbers of peculiar, grayish, depressed spots upon the surface, the spots usually having a dark purple margin. 'This injury is accompanied by a splitting or cracking of the bark, which 
becomes deeper as the cane ripens, and finally extends nearly to the pith. The spores are developed usually in the central portions of the spots, appearing to the unaided eye as yellowish elevations. Canes so attacked become dwarfed and worthless.

REMEDY. - The raspberry is very sensitive to the corrosive action of fungicides, and it must be sprayed with care. Recent experiments at the Ohio Station indicate that the dilute Bordeaux mixture may be used to advantage against this disease, although it is not a complete remedy. Apply once before the leaves come out, and two or three times afterward, though not after the blossoms open. "Care should be taken to direct the spray to the young growth, and avoid the old canes after the first application." 


\section{NURSERY STOCK}

\section{Insect Enemies of the Foliage}

The leaves of young apple trees are frequently rolled together at the tips of the terminal twigs by a greenish yellow, slightly hairy worm about half an inch long. This is the Lesser APPle Leaf-Roller. Its lifehistory is as follows: The eggs are laid in spring on the leaves of apple and other plants, the larvæ soon hatching to devour the foliage, some of which they

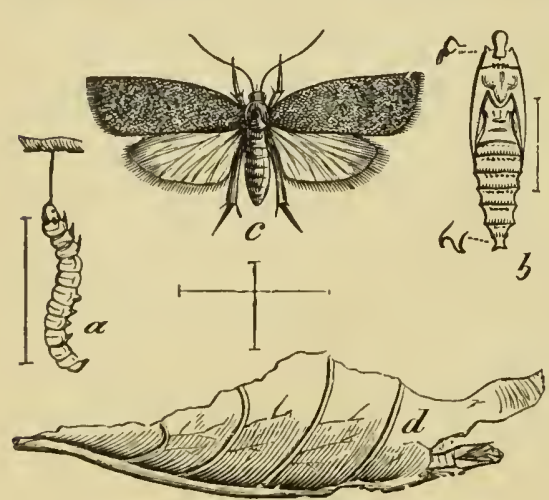

FIG. 26. Lesser Leaf-roller: $a$, larva; $b$, pupa ; $e$, moth; $d$, rolled leaf.

roll into a protective covering. Here they feed for about a month, when they pupate within the folded leaves, and a week or so later emerge as small orangeyellow moths; these moths lay eggs for another brood of larvæ, the imagos from which appear in August, being also of the same orange color. These in turn lay eggs for a third brood of worms, which develop during September, and emerge during October as glistening reddish-gray moths, which pass the winter in rubbish heaps and fence corners and deposit eggs the following spring. 
One often finds during winter, upon the twigs of nursery trees, masses of dry brown leaves, that, when pulled apart, are seen to surround a long, tubular, horn-like case. These cases contain a brownish worm or caterpillar, about half an inch long. This is the LEAF-CRUMPLER, and it often becomes one of the most injurious of nursery pests. The parent is a small grayish moth (Fig. 27, d) that deposits its eggs during June and July on apple, quince, and other trees. These eggs soon hatch into small brownish worms that construct tubular, silken cases (a) within which they remain concealed when not eating. As they grow larger they draw about the openings of their abodes many partially eaten
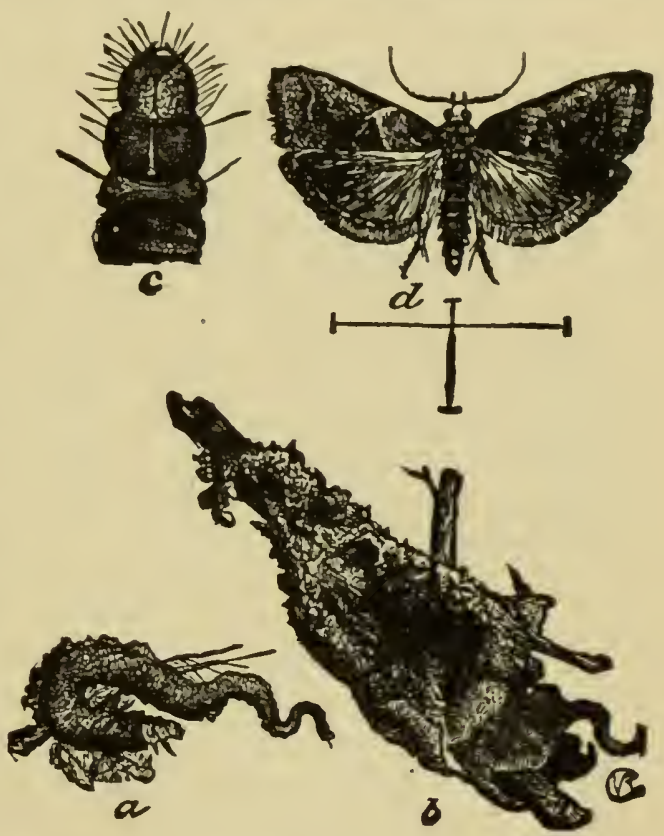
leaves, so that by FiG. 27. Leaf-crumpler: $a$, larval case; $b$, autumn there is quite a bunch surlarval case with dead leaves; $c$, front part of larva ; $d$, moth, magnified.

rounding each case (b). At the approach of cold weather the cases are attached to twigs by silken threads, and thus the winter is passed. As soon as 
the leaves appear the larvæ attack them, frequently eating out the flower buds as well. They feed until June, when they pupate within the cases. A fortnight later the moths emerge.

The Apple Leaf-SKeletonizer is a brownish or greenish larva, which spins a web upon the upper surface of the leaf, and eats the parenchyma, giving the foliage a scorched appearance. The larvæ hatch from
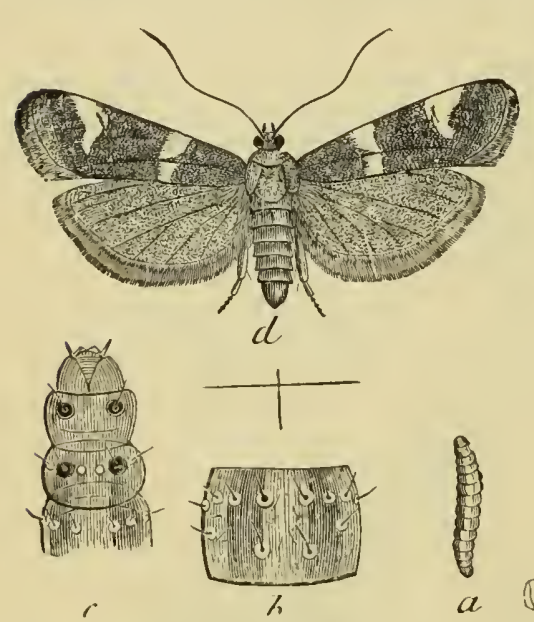
$r$
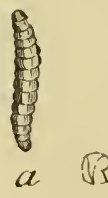
eggs laid late in spring by a little moth, and as they grow older they spin a slight protective silken web on the upper surface of the leaf, beneath which they feed. When full grown (a) they vary from an olive or pale green color to brown, are about half

an inch long, and have FIG. 28. Leaf-skeletonizer: a, larva; four black shining tu6 , part of back, magnified to show bercles on the back, markings; $c$, head and front part of just behind the head. larva, magnified, $d$, moth. magnified. About midsummer they pupate in slight cocoons, and two weeks later the moths emerge. Eggs are laid by these moths for the second brood of larvæ, which when full-grown hibernate in thin cocoons.

REMEDI:S.-All three of these pests are open to destruction by spraying with arsenites. In regions 
where the Powdery Mildew is injurious as well as these, a combination treatment may be employed, adding five or six ounces of London purple or Paris green to each barrel of Bordeaux mixture. Where fungicide treatment is not necessary, spray with arsenites and lime (adding the lime to prevent injury to the young and tender foliage, as explained in the introduction, p. 2o) whenever either of the insects threaten injury,-the earlier the better.

\section{Fungous Enemies}

There are at least three fungous diseases of young nursery trees to prevent which spraying pays. They are: (I) the PEAR LEAF-BLIGHT, which affects a quince as well as pear stocks; (2) the Powdery Mildew, which occurs upon apple and cherry, and (3) the LEAFBLIGHT or LEAF-SPOT of the plum and cherry.

According to Mr. B. T. Galloway, the body or vegetative system of the PEAR LEAF-BLIGHT consists of very minute, short, colorless filaments, which grow between and through the delicate cells of the leaf, "destroying all the latter with which it comes in contact, and using their nourishment for building up its own structure. As a result of this process, the leaf shows, here and there on the surface, small, more or less circular, dark brown spots; these spots rapidly enlarge, and by running together soon cause the entire leaf to turn brown and then fall off. Before the latter takes place, however, a close examination of the dis- 
eased spots will reveal numerous little black specks; these contain the spores or reproductive bodies of the fungus, which escape by rupturing the cuticle of the leaf with which they are covered. Under proper conditions of moisture and heat the spores germinate, and if this takes place on a pear leaf, the germ tube bores its way into the tissues, soon develops into colorless filaments, like those already described, and these in turn give rise to more spores." The fungus passes the winter by means of the late summer spores which remain attached to the fallen leaves.

Remedy.-_"Spray first with the Bordeaux mixture when the leaves are about two-thirds grown; then follow with other applications of the same preparation at intervals of about twelve days, until five or six sprayings in all have been made." (Galloway.)

The fungus of the APPLE POWdery Mildew differs materially from the species affecting pear leaves just discussed. "Its vegetative system," says Mr. Galloway, "instead of growing on the inside of the host is almost wholly external, and obtains its nourishment by means of suckers which it sends into the cells of the leaf or stem as the case may be. It covers the various parts of the plant with a grayish, powdery, meal-like growth-hence the name Powdery Mildew."

REMEDIES.- "Spray the seedlings with the ammoniacal solution or copper carbonate, first when the leaves are about half grown, and thereafter at intervals of 12 days. Following this plan three sprayings will usually be made before budding, and at least two 
after this operation, making five in all." (Galloway.) Or the Bordeaux mixture may be used.

The Leaf-BLight of the plum and cherry may be
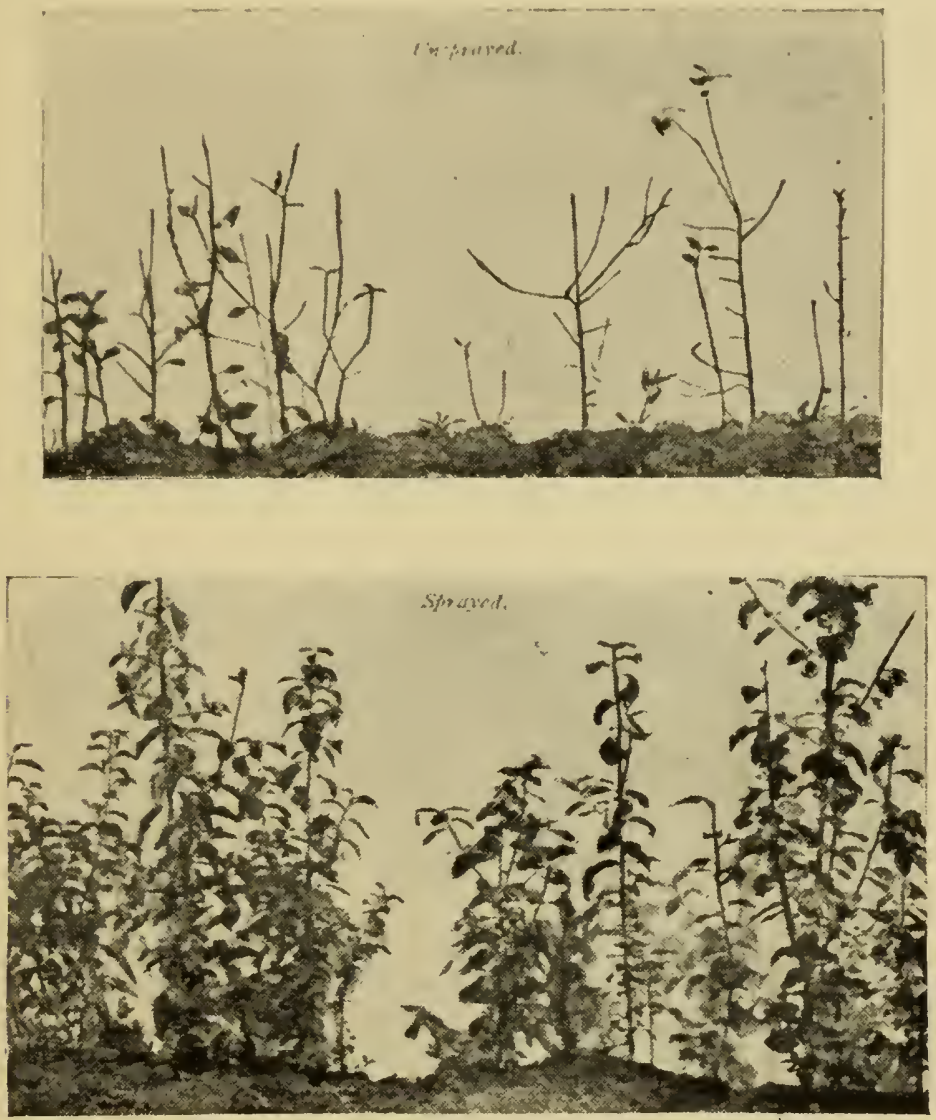

FIG. 29. Spraying for Plum Leaf-blight.

prevented by spraying with the Bordeaux mixture. Apply first when the leaves are one third grown. "Between this date and the time for budding three 
more applications should be made at as nearly regular intervals as possible. Ten days or two weeks after the buds are inserted make the fifth application, then follow with the sixth two weeks later." The effect of spraying plum stocks is well shown in Fig. 29, reproduced from the Fournal of Mycology. 


\section{PART III}

SPRAYING SHADE TREES, ORNAMENTAL PLANTS, AND FLOWERS 


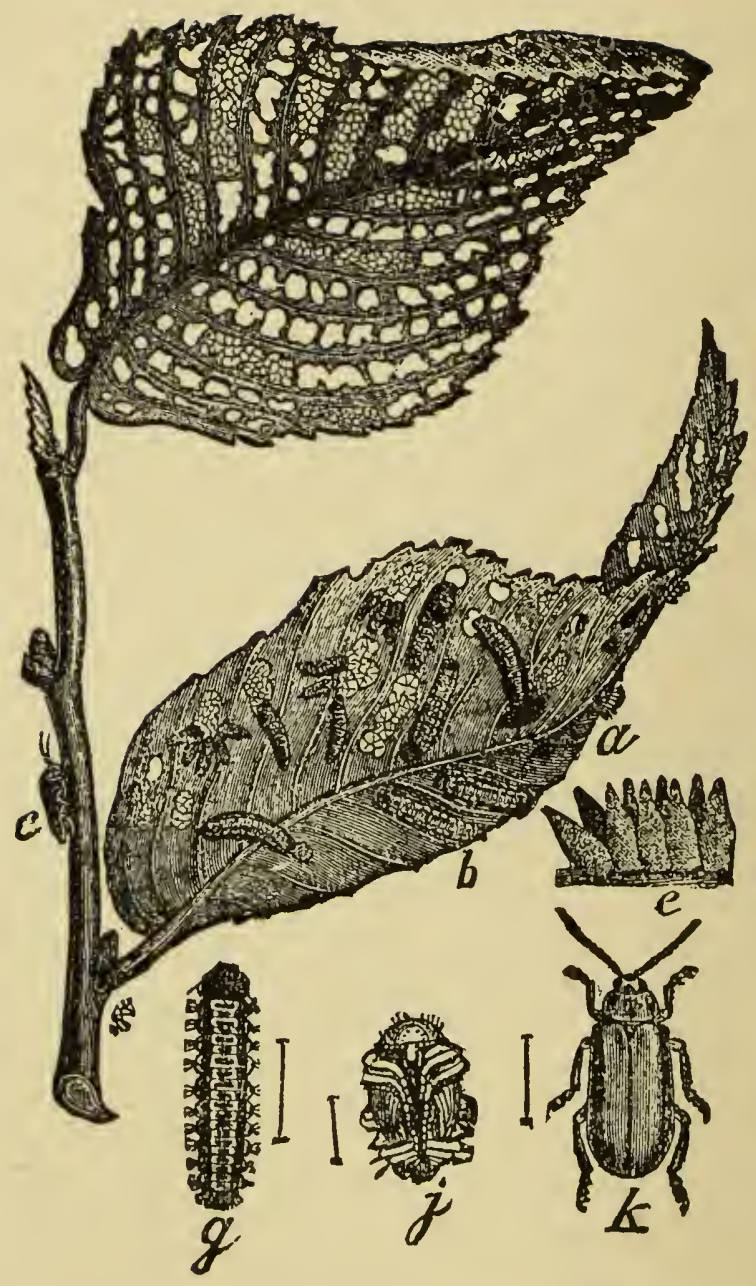

Plate IV. TRANSFormations OF THE EIM-LenF BEETLE. 


\section{SHADE TREES}

\section{Insect Enemies of the Foliage}

The Woolly Maple Bark-Louse is often one of the most destructive shade-tree pests. Its presence is manifested in spring and early summer by the occurrence upon the twigs of a brown, circular, leathery scale about $1 / 4$ inch in diameter, beneath which is a peculiar white, fluffy, cottony mass. In the spring there may be found, in each of these masses, great numbers (from 700 to 1,000 ) of small, white, spherical eggs. Early in summer these eggs hatch into young lice, which scatter over the trees, wandering about on the twigs and leaves for a few days, and, finally, fixing themselves upon the lower leaf surface, insert their tiny beaks and suck out the sap. They remain in this position several weeks, when a few of them become fully developed winged males. These mate with the remainder, which are females, and soon die. But the females remain upon the leaves until nearly time for them to fall in autumn, when they desert them and migrate to the twigs, attaching themselves by inserting their beaks into the bark. Here they remain until spring, the eggs gradually developing.

REMEDY.-Spray infested trees in June, when the lice have just hatched, with kerosene emulsion. 
The twigs of deciduous and coniferous trees are often infested during winter by small bags or sacs (Fig. 30, c) suspended to the leaves or branches. If one of the larger of these bags be cut open, there will be found within it a brown, membranous shell (the pupa-case of
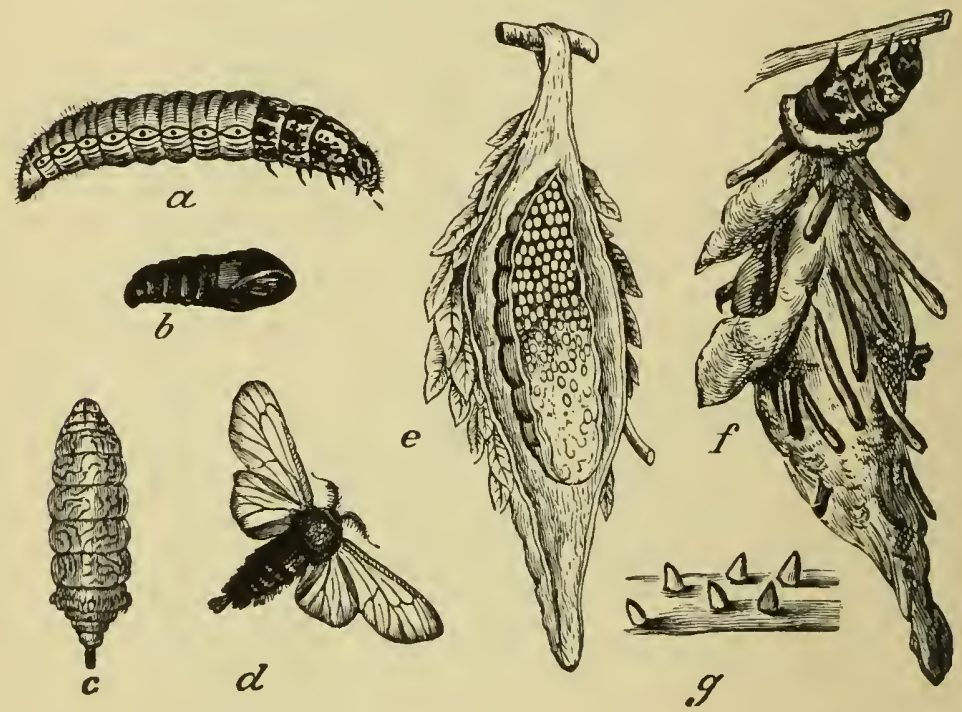

FIG. 3o. Bag-worm; $a$, larva; $b$, male pupa ; $c$, female moth; $d$, male moth; $e$, bag and pupa-case cut open to show eggs; $f$, full-grown larva with bag; $g$, young larvæ with their conical coverings.

the moth) filled with many small, yellow eggs $(c)$. In this condition the BAG-WORM or BASKET-WORM passes the winter. Late in spring the larva hatch, and form little cases of fragments of leaves fastened together by silken threads. Beneath these cases $(g)$ they feed upon the foliage, enlarging them as the larva develop, and during later life using bits of twigs or stems in their construction. When fully developed, the worms 
descend to the earth by means of silken threads, and crawl about until they reach the bases of other trees, which they ascend. This is the way the species migrates. The larve pupate within the cases, and about three weeks later change to moths. The two sexes of the moths differ greatly, the male (d) having well developed wings, while the female $(c)$ is wingless. The latter deposits her eggs in the empty pupa-case from which she has emerged, falls to the ground, and dies.

RF.MEDIES.--Spray with London purple or Paris green early in summer when the worms are young.

The larva of the WHITE-MARKED TUSSOCK-MIOTH is one of the most beautiful of our caterpillars. If the trunks or larger limbs of maple, apple, elm, or any other of the trees infested by this insect, be examined in autumn or winter, one may find, scattered here and
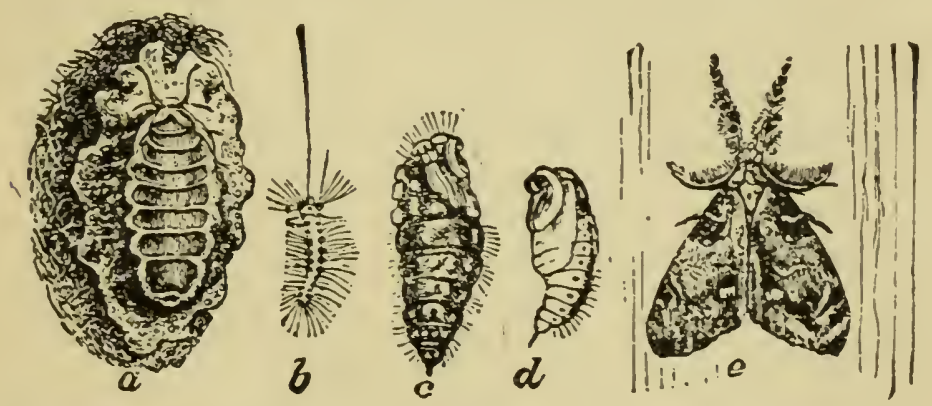

FIg. 3 I. White-marked Tussock-moth: $a$, female moth on cocoon; $b$, young larva hanging by thread; $c$, female pupa; $d$, male pupa; $e$, male moth.

there upon the bark, thin gray cocoons, many of them being covered with large bunches of spherical white eggs fastened together by a protecting froth-like mass. 
In May, soon after the leaves come out, these eggs hatch into small caterpillars, which feed upon the foliage, becoming full-grown in six or seven weeks. Their general color is bright yellow, with head and tubercles on rear of back red, and four cream-colored tufts on back. About the middle of July the caterpillars spin thin, whitish cocoons upon the bark, and a fortnight later come forth as moths. These lay eggs for a second brood, which complete their transformations before winter sets in. The male moth differs greatly from the female moth, the former being winged (Fig. 3 $\mathrm{I}, e$ ), while the latter is wingless (a). The female crawls upon the top of the cocoon $(a)$ as soon she emerges from the pupa state, where, after mating, she deposits her eggs in a single mass and dies.

REuEDIES.-Spray trees as soon as caterpillars are noticed, with Paris green or London purple.

The work of few insects is more universally known than that of the FALL WEB-WORM. Late in summer and early in autumn the conspicuous, unsightly webs of this pest may be seen in nearly every orchard and hedgerow over a large portion of the United States. The adult is a pretty, white moth (Fig. $3 \mathrm{I} x$ ), which deposits eggs on the leaves of various trees early in summer. These soon hatch into young caterpillars that begin at once to spin a protective web. They feed upon the parenchyma of the foliage, leaving the network of veins, and grow quite rapidly, enlarging the web as they develop. The full-grown larva are a little more than an inch long, with the body densely 
clothed with yellowish hairs. They now leave their nests and descend to the ground, where they spin

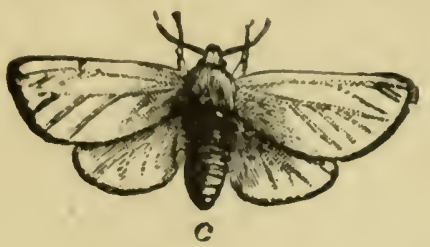

slight silken cocoons within which they change to pupx. REMEIIES.
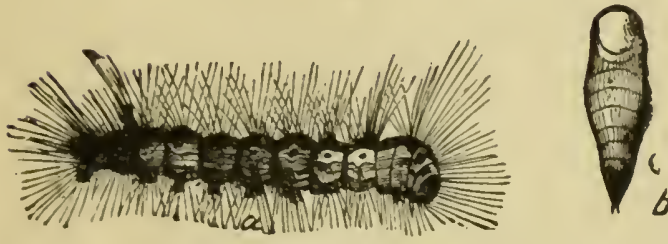

It is an easy matter to cut the webs off and burn or crush the larva. 'The Fig. $3^{1 x}$. Fall Web-worm: a, larva; b, pupa : pests may also $c$, moth.

be destroyed by spraying with London purple or Paris green when the larva are young.

During recent years the Imported Elm LEAF-BEetle. has been exceedingly destructive in many cities of the Eastern States, to that loveliest of shade-trees, the elm. The eggs (Plate IV., a) are laid on the under side of the leaf in two or three rows. In about a week the larvæ hatch and begin eating the leaves, causing them to look as if riddled with fine shot. They become fully grown $(g)$ in two or three weeks, when they descend to the ground, and change to pupæ $(j)$. Ten days later the perfect beetles ( $c$, natural size; $k$, magnified) come forth and eat the leaves, although the damage done by the insect in this state is less than that done by larvæ. There are three or four broods 
each season, and the beetles pass the winter in hollow trees and under old leaves.

Remedies. - Spray with London purple or Paris green ( 4 ozs. to 50 gallons water) when the eggs are being laid, in order to kill the larva before they have done any damage. The addition of a little flour to the poison mixture seems to render it more effective. To reach the tops of high trees a pump of considerable power is required. 


\section{THE ROSE}

\section{Insect Enemies of the Foliage}

The Rose Sucg is the young or larva of a fourwinged saw-fly. It eats the pulp of the leaves, giving the foliage a scorched appearance. The eggs are laid singly in the skin of the leaf, and the larva hatch in about a fortnight. They become full-grown in three weeks: they have a small, round, yellowish head, and a green body, which is soft and nearly transparent. Leaving the bushes they burrow into the soil an inch or two and make oval cocoons of silk mixed with particles of earth. They remain in these until the following season, when they emerge as flies.

REmedies.-Spray with hellebore or insect powder.

The Rose LeafHOPPER is a small whitish insect, found on the lower surface of rose leaves, sucking out the cell contents and giving the upper surface a
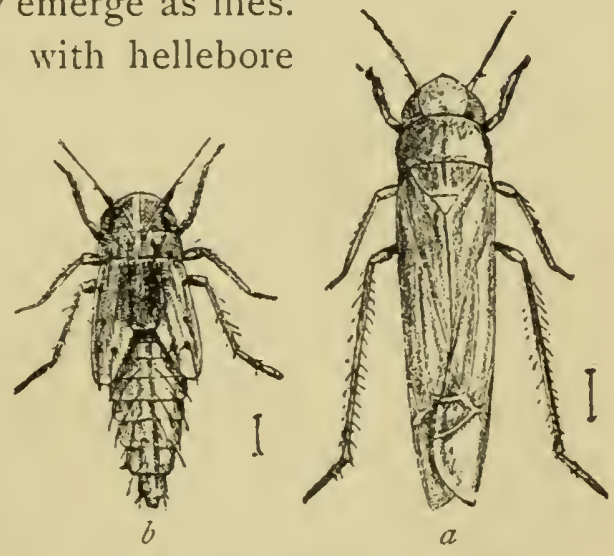
white-spotted a p-FIg. 32. Rose Leaf-hopper: $a$, adult ; $b$. pearance. The adult pupa. Magnified.

(Fig. $3^{2}, a$ ) is a little more than I-Io inch long, with a yellowish-white body, and white semi-transparent wing 
covers. It has long hind legs, by means of which it is enabled to make tremendous leaps when disturbed.

REMEDIES.-These little pests are much easier to destroy before they are fully developed than afterwards. Spraying or dusting with pyrethrum, or insectpowder, is a simple and efficient remedy. Tobacco, in the form either of a powder or a decoction, is also good; and kerosene emulsion will destroy the pests.

\section{Flowers and Potted Plants}

Greenhouse plants are often seriously injured by minute, reddish mites that congregate on the lower leaf surface, spinning a fine protective web and sucking out the juices of the plants through their tiny beaks. These are RED SPIDERS. They multiply beneath their silken webs, where one may find colonies of individuals (so small as to be scarcely visible to the naked eye) in all stages of existence. The infested leaves assume a yellowish hue, and many of them finally fall off.

Remedies. - The Red Spider flourishes best in a dry atmosphere. It is seldom troublesome in greenhouses where the air is kept saturated with moisture and the plants are sprayed with water every day. In window-gardens the plants should be sprayed with soap-suds, tobacco decoction, or kerosene emulsion, or dusted with fine tobacco or insect powder, as soon as they show signs of the presence of this pest.

There are many different species of APHIDES, PLANTLICE, or "GREENFLIES," affecting various flowering- 
plants. But all are quite similar in life-history and habits, and the same remedies apply to each. They all multiply with marrellous rapidity, on account of their habit of giving birth to living you $\mathrm{ng}$ without the presence of male aphides They mature rapidly, and ob. tain food by in. serting their

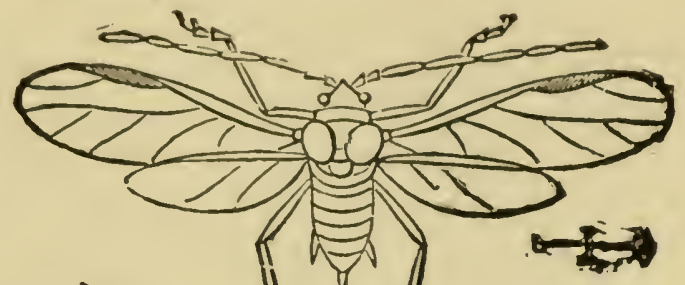
pointed beaks Fig. 33 . Aphis: $\alpha$, wingless form, magnified; into the stem or
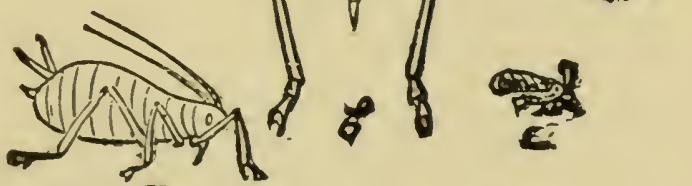

leaf and sucking out the sap. There are generally two forms of them, one being winged (Fig. 33, b,c) and the other wingless $(a)$. These insects are the commonest pests of the flowering-plants.

REMEDIES.-Spray with kerosene emulsion, fish-oil soap, or tobacco decoction. 



\section{PART IV}

SPRAYING VEGETABLES, FIELD.

CROPS AND DOMESTIC ANIMALS 


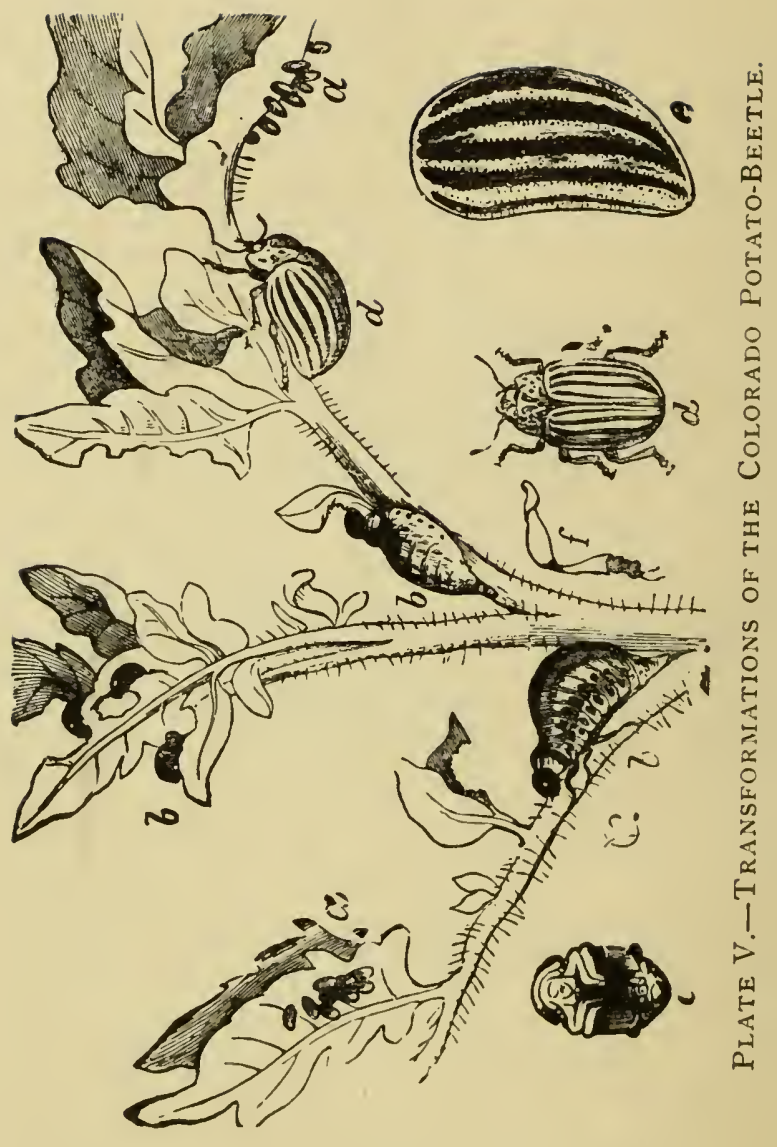




\section{THE POTATO}

\section{Insect Enemies of the Foliage}

The Colorado Potato-beetle (Plate V) deposits its orange-colored eggs $(a)$ in masses, varying in number from a dozen to fifty or more, on the under surface of the potato-leaf, and occasionally also upon the leaves of grass, smart-weed, or other plants in the potato field. They hatch about a week later into peculiar little grubs (b) that feed upon the foliage a few weeks. They then descend to the ground, where just beneath the soil surface, or under the rubbish above it, they change to pupx (c). About ten days later they emerge as perfect beetles. There are from two to four annual broods, the number varying with the latitude; and the insect hibernates in the beetle state.

REMEDIES.-Spray with six or seven ounces of London purple or Paris green to 50 gallons of water. For this purpose London purple seems preferable, on account of its cheapness and finely-powdered condition. The application should be made as soon as the beetles appear, in order to kill off the first brood, and it must be repeated as often during the season as is necessary to keep the pests in check.

\section{Fungous Enemies}

There are at least two distinct diseases which are called the Potato Rot or Potato Blight. One of these is the Late Blight or Downy Mildew, due to 
the fungus Phytophora infestans; and the other is the EARly Blight or Leaf-SPOT Disease, due apparently to a fungus called Macrosporium solani. They may usually be distinguished by the fact that leaves affected by the former have on their under surface a white, velvety mould, visible to the naked eye, but more readily seen through the microscope: with the early blight no such mildew is present. With both the foliage of plants attacked becomes spotted with brown, and the spots gradually enlarge, finally involving the whole leaf, and then cause the stems to wilt and wither.

According to Prof. F. L. Scribner, the life-history of the Downy Mildew. Potato Rot Fungus may be summarized as follows: "The spores lighting upon the leaves of the potato germinate in drops of dew or rain, and the product of germination-the zoösporespenetrate to the interior tissues of the plant, and after growing for a time through these tissues, the mycelium sends out, chiefly from the under surface of the leaves, slender fruiting branches, whereon are produced a new crop of spores. These may carry the disease to the other plants in the field, or to the other parts of the same plant; that is, they may serve to spread the disease in the tops, which we term blight, over the entire field, or by being washed into the ground they may reach the tubers and cause the rot. The fungus once having gained entrance to the tubers, may or may not vegetate rapidly. Its presence, however, is soon made evident by a browning of the flesh underlying the skin, 
and by more or less extensive discoloration and depression of the latter." When such affected tubers are planted, the disease is very likely to develop in the plants from them.

The EARLy Bught appears early in summer in the shape of small brown, brittle spots, scattered over the leaf. Careful inspection show's that their upper surfaces are more or less roughened by darker areas rising above the dead gray tissue. The spots gradually enlarge, and finally run together to form large brown patches, the intermediate tissues becoming yellowish or sickly green in color. The entire plant finally withers, and dies long before the proper period, the tubers being small-generally less than half full size. But the tubers do not rot and are of good quality. This fungus has proven difficult to study in the field, the spores being produced only on part of the affected plants. It winters over in the spore stage on the dead vines.

Besides the two maladies already discussed, there is a potato disease due to Bacteria, although it is probable that the Macrosporium blight has frequently been attributed to these organisms. Bacteria often develop in tissues invaded by the fungus just named; but there are good reasons for believing that a genuine bacterial trouble frequently develops in all parts of the plant. It generally starts from the seed planted, which becomes rotten. The vines die prematurely, often wilting rather suddenly, and the young tubers 
decay. This disease is more troublesome in southern latitudes than at the north.

REMEDIES.-A number of experiments have shown that these diseases may be prevented by spraying with the Bordeaux mixture, provided the seed potatoes used are free from infection. To be sure of this, seed should be obtained from regions where blight and rot do not occur upon potatoes, or potatoes which were sprayed the year before. Then spray three or four times with the Bordeaux mixture, making the first application when the vines are about one third grown, or earlier if signs of the disease appear, and repeat the

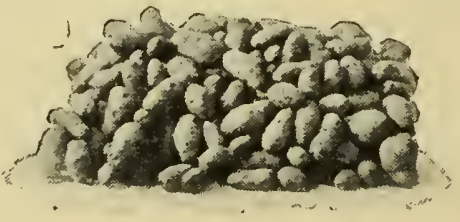

$a$

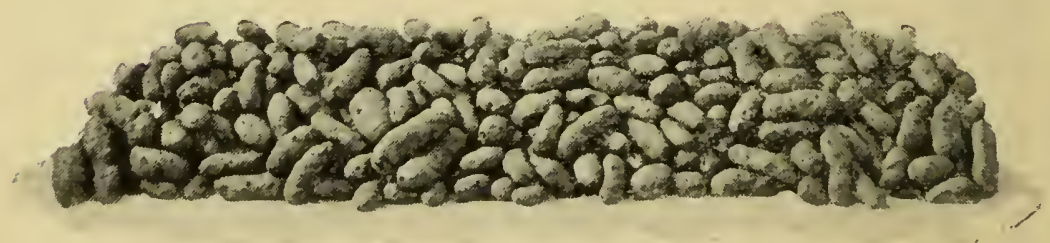

$b$

FIG. 34. (a) Yield of unsprayed plot; (b) of sprayed plot.

application when it is washed off - in about a fortnight usually. Add half a pound of London purple or Paris green to each barrel of the mixture whenever the Col- 
orado Beetles threaten injury. While the best results are most likely to be reached when the seed is not infected, very satisfactory ones are obtained from spraying crops from ordinary seed.

The beneficial effect of treatment with Bordeaux mixture, as it resulted in some experiments by Professor Jones, of Vermont, is shown in Figure 34. The treated vines yielded marketable tubers at the rate of 29 I bushels per acre, while those untreated yielded only at the rate of $991 / 2$ bushels per acre.

IX 


\section{THE CABBAGE}

\section{Insect Enemies of the Leaves}

The transformations of the IMPORTED CABBAGEWORM-the most destructive insect affecting cabbage-are illustrated in Fig. 35. The adult is a common white butterfly, which deposits, singly or in clusters of two or three each, small, yellowish eggs
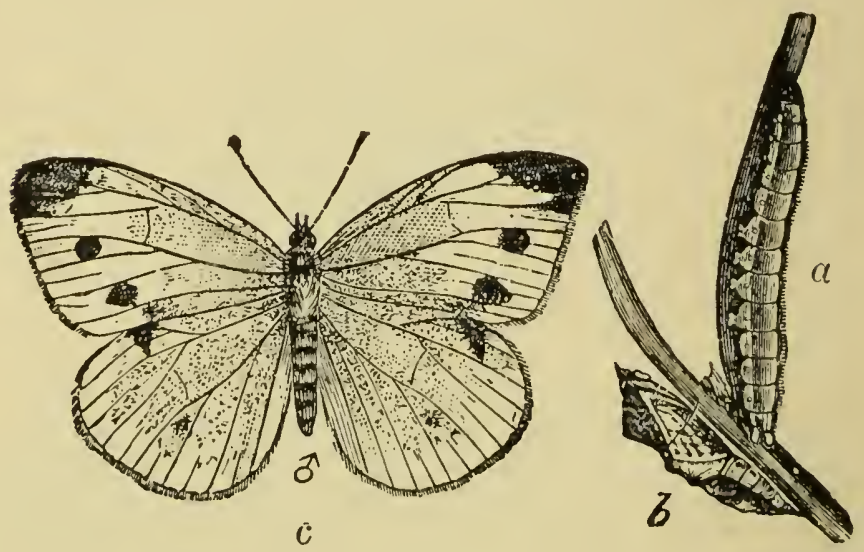

FIf. 35. Imported Cabbage-worm; $a$, larva ; $b$, chrysalis ; $c$, female butterfly;

upon the cabbage. The eggs soon hatch into little, green larvæ that feed upon the leaves. In about two weeks they become full-grown (a), when they desert the cabbage plants, and finding some suitable shelter -beneath a board or under the coping of a fence- 
change to chrysalids (b). They remain in this condition about ten days, when they emerge as butterflies, to lay eggs for another brood of worms. The winter is passed in the chrysalis state.

REmEDIEs.-Pyrethrum (insect-powder or buhach), hot water, and kerosene emulsion are the best remedies. The insect powder may be mixed with water, in the proportion of one ounce to four or five gallons of water, and sprayed upon the plants. Dr. Riley states that "every worm visible upon the cabbages may be killed by the use of hot water at the temperature of I $30^{\circ}$ Fahrenheit. The water may be boiling hot when put in the watering-can, but it will not be too hot when it reaches the cabbage leaves." Kerosene emulsion can advantageously be used when the plants are young, though there would appear to be danger of tainting the heads if applied to the fully developed plants. Whichever method of treatment is adopted, it should be carried into practice at frequent intervals, thus keeping the worms well in check. If the plants are sprayed with insect-powder once a week during the time the worms are present, they will cause little or no trouble. Young cabbages which have not begun to form heads may be sprayed with Paris green or London purple and water, but this should not be done under any circumstances after the heads are formed.

There are several other caterpillars affecting cabbage-especially the Cabbage Plusia and the Zebra CATERPILlaR-which sometimes necessitate a spraying with kerosene emulsion or insect-powder. 
The CABbage Aphis is a small, greenish insect, generally covered with a whitish, mealy coating, that occurs in great numbers on the leaves and in the heads of cabbage. During the summer months it reproduces viviparously, but in autumn true males and females are developed, eggs being deposited by the latter upon the cabbage leaves.

REMEDY.-Kerosene emulsion and fish-oil soap are the most effective liquid insecticides that can be used against this insect.

Young cabbages are often attacked by flea-beetles, especially the Wavy-STRIPED Flea-Beetle. It is a small, shining black beetle, r-ro inch long, with a broad, yellow, wavy stripe on each wing-cover. It feeds upon the surface of the leaf, gnawing out little pits. The females deposit minute whitish eggs upon the roots of cruciferous plants, such as radish, cabbage, turnip, etc., and the larvæ feed upon these roots, sometimes doing serious damage. The full-grown larva $(a)$ is about $\mathrm{r} / 4$ inch long, with a yellowishwhite body, and brown head.

REMEDIES. - Spray the plants with a strong tobacco decoction, or dust on powdered tobacco.

In the Southern states the Harlequin CaBbaGEBUG is a very troublesome pest. It feeds upon a variety of cruciferous plants, such as cabbage, radish, mustard, and turnip; and passes the winter in the adult state. Early in spring eggs are deposited upon mustard or radish plants, upon which the resulting bugs develop. The second brood attacks the cabbage 
and the insects continue to develop upon this crop until autumn. According to Mr. Howard Evarts Weed of
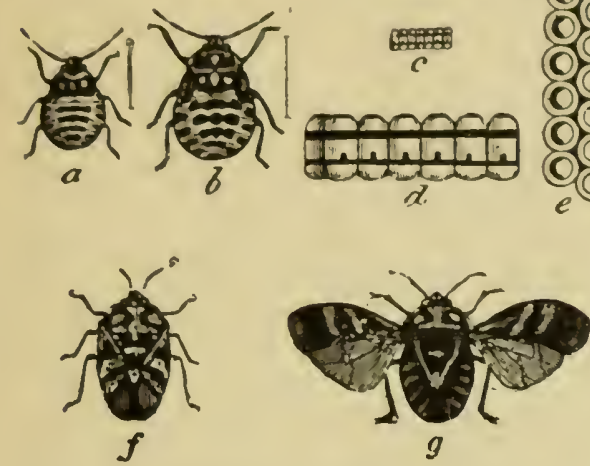

Fig. 36. Harlequin Cabbage-bug: $a, b$, nymphs; $c$, eggs : $f$, adult; $g$, adult with wings extended-all natural size ; $d$, eggs, side view; $e$, eggs, view from above $-d, e$, cnlarged.

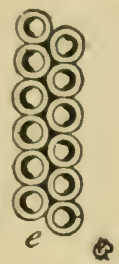

the Mississipi experiment station, "there is but one efficient remedy for this insect, which is, to destroy the brood which lives over winter, when they congregate upon the mustard or radish plants. Here they can be destroyed very easily by the application of kerosene (not emulsified) by means of a hand force-pump or common watering bucket. If the insects are thus destroyed early in the season, it will almost wholly prevent injury later. The insects fly but little, and are thus not apt to come from a neighboring field." Those bugs or eggs which may be seen on cabbage, should be picked off and destroyed. 


\section{GRAIN CROPS}

\section{Insect Enemies}

The $\mathrm{CHINCH}$ Bug has long been recognized as one of the arch-enemies of American agriculture. The adult (Fig. $37, h$ ) is a small blackish insect, slightly less than $1-5$ inch long, with the legs dark yellow, and their tips black. The females deposit eggs about the roots of grass and grain. From these hatch young bugs $(c)$
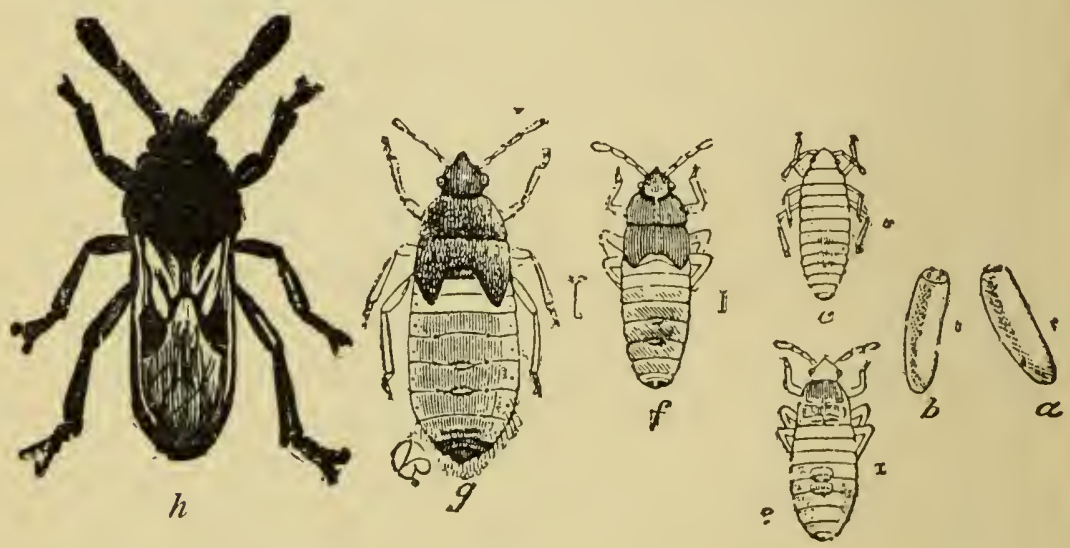

FIG. 37. Chinch Bug; $a, b$, eggs; $c, e, f$, young; $g$, nymph or pupa ; $h$, adult. Magnified.

that do not differ in general form from the adults. They suck the sap from various plants of the grass family, gradually increasing in size, and moulting at intervals. In a few weeks they become nearly fullgrown, but instead of changing to a quiet chrysalis 
state, they simply moult again and continue feeding as before. In these early stages, which correspond to the larva and chrysalis, they are called nymphs. The older nymphs $(g)$ are nearly as large as the full-grown bugs, differing mainly in the absence of wings. In about a week they again moult and come forth as adult bugs.

REMEDIES.-Chinch bugs are easily killed by kerosene emulsion, and by means of improved sprayingmachines this substance can be used against them to good advantage. The best time to choose in which to kill them is when they are migrating from field to field.

Corn, oats and other field and garden crops suffer greatly from the attacks of CUT-WORMS, of which there

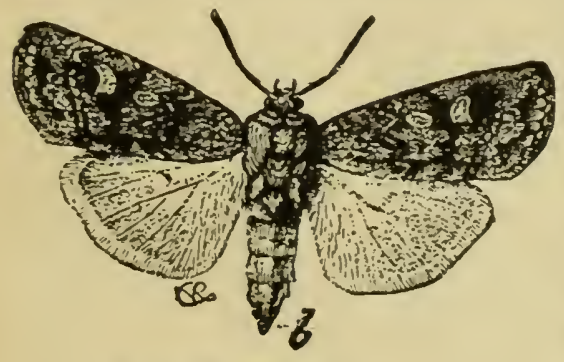
are many species. They are larvæ of medium-sized, night-flying moths, and are thick, naked worms that curl up when disturbed. Most of them feed upon

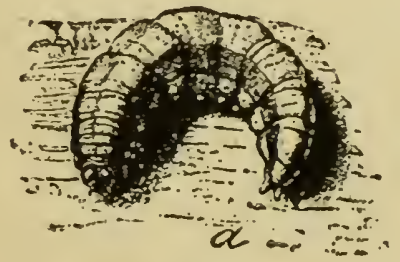
grass or clover when young, becoming about half grown by winter time, when they seek the shelter of some log FIG. 3 S. Variegated Cut-worm: $a$, or stone, or burrow into larva; $b$, moth. the soil. Here they hibernate, and in spring come forth in search of food. They now attack a variety of young plants, biting off 
the stems and feeding upon the leaves. They become full-grown in spring or in early summer, and pupate beneath the soil surface, and three or four weeks later emerge as moths. The larva $(a)$ and moth $(b)$ of the Variegated Cut-worm (Agrotis saucia) are represented, natural size, in Fig. 38 . Some species have two or more broods each season, while others have but one. Cut-worms are especially likely to do damage in fields and gardens close to grass-lands, and to crops immediately following grass.

Remedies.-Spray a small plat of clover with Paris green, and then cut it late in the afternoon and strew in bunches over the field to be protected. The worms prowling about at night eat of the poisonous baits and are killed.

The ARMY-WORM hatches from eggs laid by a handsome brown moth between the sheaths of grass blades. The larva are at first green, but later become ornamented with longitudinal stripes of yellow, gray, and black. They feed upon the leaves of grass wheat, oats, rye, etc., and become full-grown in about a month. Occasionally they become so numerous that they exhaust their food-supplies, and then are forced to seek other feeding-grounds. At such times the "armies" appear, and moving in solid masses sweep all grasses and cereals before them. The larvæ pupate in earthen cells, emerging a fortnight later as moths.

REMEDIES.-One of the most promising methods of combating this insect is that of thoroughly spraying strips of grass or other crops in front of the advancing host with mixtures of London purple and water. 


\section{DOMESTIC ANIMALS}

\section{Insect Enemies}

Our various domestic animals frequently suffer from the attacks of LicE. Three of the commoner species affecting horses and cattle are shown in Fig. 39. Animals affected by them lose flesh and are weakened. The lice generally deposit their eggs or "nits" on the hairs.

REMEDY.-The best method of destroying lice is to spray or wash the infested animals with a well-

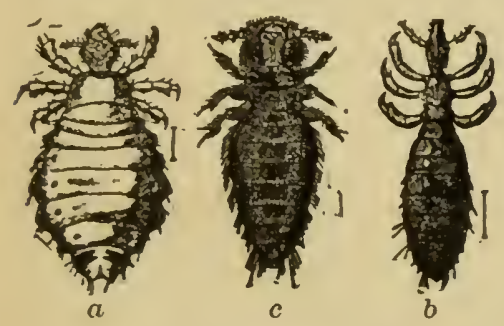

FIG. 39. Lice : $a, b$, sucking oxlice: $c$, biting horse-louse. Magnified.

prepared kerosene emulsion. If this is well made it can be applied to cattle and horses, hogs and sheep, with no danger of injury to them, while it will destroy all the lice with which it comes in contact. Prof. C. P. Gillette, who first gave this method a thorough trial, recommends applying it with a force-pump and spray nozzle, rubbing it in thoroughly with the finger-tips at the same time. It kills the lice, and leaves the hair of the animal in good condition. The lice may also be destroyed by treating with a strong tobacco de- 
coction-a pound of tobacco being boiled in two gallons of water-or a wash of carbolic-acid soap. But the first-named remedy is best. The stalls and woodwork of the quarters occupied by the infested animals should also be treated.

The HORN FLY is a recently imported insect that often annoys cattle by sucking their blood and lighting upon their horns (Fig. 40.). The eggs are deposited

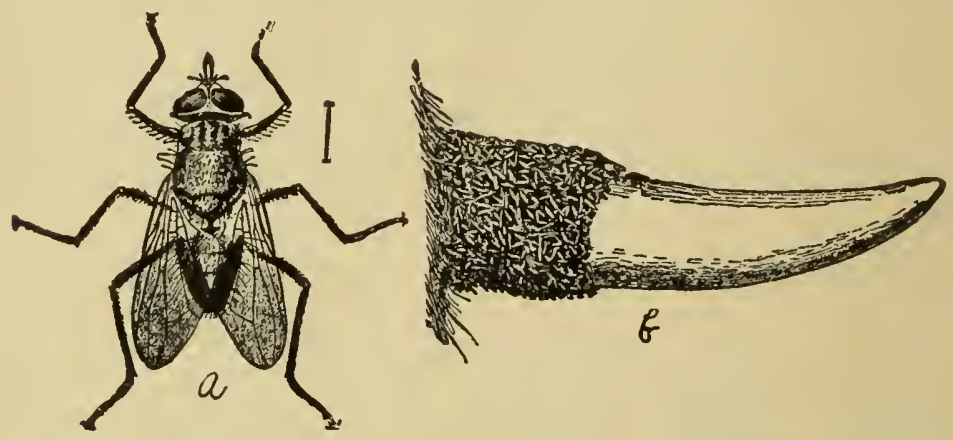

FIG. 40. $a$, Horn Fly, magnified; $b$, cow-horn, with band of resting flies, reduced.

in freshly dropped cow-dung, in which the larva develop, and pupate in the soil beneath. There are four or five broods each season. During hot weather the transformations of the insect-from egg to imagomay be completed within two weeks.

Remedies.-Spray cattle twice a week, either with kerosene emulsion, to which a little tobacco decoction has been added, or fish-oil to which a little carbolic acid has been addled. Or rub on by means of a brush or cloth. 


\section{INDEX.}

Aphides . . . . . 1 I 2

Aphis . . . . . 60

Apple, The . . . . 55

curculio . . . . 57

flea-beetle . . . 59

leaf-roller . . . 96

rot...... 62

scab . . . . . $6 \mathrm{r}$

skeletonizer . . . 98

worm . . . . 56

Army-worm . . . . I 28

Arsenites and copper carbonate . . . . 33

Bag-worm . . . . . I06

Basket-worm . . . . 106

Black-spot . . . . . 6 I

peach aphis . . . 67

rot . . . . . 9I

Bordeaux mixture . . 24

and arsenites . . . 33

Brown-rot of stone fruits,

(5) 68

Bud-moth . . . 15,92

Cabbage, The . . . 122

aphis . . . . I 24

plusia . . . . . 123

worm . . . . . 122

Canker-worm. . . . I $3,5^{8}$

Carbonate of copper . . 30

Cherry, The . . . 73

aphis . . . . 73

leaf-blight . • . 74

Chester-sprayer, The . . 39

Chinch-bug

126

Codling-moth : io, 56 , 6 is Colorado potato-beetle . I I 5 Combining insecticides and fungicides
Copper carbonate Page

sulphate . . . . 3I

Cost of spraying materi-

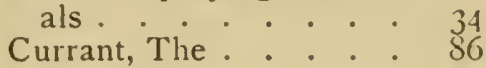
aphis . . . . 89

bug . . . . . 88

leaf-hopper . . . 87

worm . . . . 86

Cut-worms . . . . I 27

Development of parasitic fungi . . . . . I 5

Domestic animals . . I 29

Downy mildew of grapes, I 5, 92 potato . . . II

Eau celeste . . . . 29 modified . . . . 30

Elm leaf-beetle . . . 109

Eye-spotted bud-moth . 60

Fall web-worm . . . IoS

Feeding-habits of insects I4

Fish-oil soap . . • • 23

Fruit-bark borer. . . . 66

Fungi, parasitic . . . I 5

Fungicides . . . . I $\$$

used in spraying . . 24

Gooseberry, The . . 86

mildew . . . . 89

Grain-crops . . . . 126

Grape, The . . . . 9 I

flea-beetle . . . 9 I

Harlequin cabbage-bug - 124

Hellebore . . . . 20

Horn-fly . . . . 130

Hyposulphite of soda . $\quad 3 \mathrm{I}$

Inported cabbage-worm . I 22

Insecticides . . . . . I8

Insect-powder . . . . 20

32 Insects, feeding-habits of, I 4 
spraying against . . 10 Kerosene emulsion . . 20 Leaf-crumpler . . . 97 Lice skeletonizer

Lichens

Lime-spray

and London purple Liver of sulphur London purple and lime

Lye solution

Maple bark-louse

Modified eau celeste

Mycelium

Nursery stock

Oyster-shell bark-louse

Orange . . . . .

Parasitic fungi, development of .

Paris green

Peach

\section{aphis$$
\text { rot }
$$

Pear, The

$$
\text { slug }
$$

$$
\text { leaf-blight }
$$

Pear psylla

Pear scab.

Philosophy of spraying

Plum, The

$$
\text { curculio, I2, 57, 63, } 67,69,73
$$

\section{gouger}

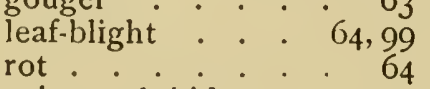

Potassium sulphide . . 3 I

Potato, The

beetle .

$$
\text { rot. }
$$

Powdery mildew

I'recautions in spraying.

l'rejudice against spray-

ing

Pruning trees
Pyrethrum

Page

Pyrethro-kerosene emulsion . . . . . . 22

Quince, The . . . . 72

Raspberry, The . . . . 94

anthracnose . . . 94

cane-rust . . . . 94

slug . . . . . 94

Red-legged flea-beetle . : 67

Red-spider . . . . . II 2

Resin washes . . . . 75

Rose leaf-hopper . . . III

slug . . . . . I I I

Shot-hole fungus : . $\quad 64$

Soda hyposulphite . . . 3 I

Spraying against insects . IO and the weather . . 46

apparatus . . . 37

$\begin{array}{lll}\text { cost of . . . . } 43 & 43\end{array}$

calendar . . . . 48

materials, cost of . . 34

nozzles . . . . 42

philosophy of . . 18

precautions . . . 52

prejudice against . . 35

profits of . . . . 45

trees in blossom . . 47

Strawberry, The . . 8 I

leaf-blight . . 84

leaf-beetles . . . 84

leaf-roller . . . 82

root-worms . . . 84

slug . . . . $8 \mathbf{r}$

Sulphate of copper . . 3I

Tent caterpillar . . . 58

Tobacco decoction . . . 23

Variegated cut-worm . I 27

Wavy-striped flea-beetle . I 24

Whale-oil soap . . . . 24

White-marked tussockmoth . . . . . 107

52 Woolly aphis . . . 56

bark-louse . . . I05

35 Zebra caterpillar . . . 123 


\section{ลิ่าก}

\section{ADVERTISEMENTS $-\mathrm{O}$}

At the present time every gardener, farmer, and fruit-grower should own a spraying-machine of some kind.-13. T. Gal.Lowar.

$$
\text { ฮู) }
$$




\section{THE PERFECTION OUTFIT}

Stirs the liquid automatically, and will SPRAY 100 trees per hour. Has ten feet of discharge hose, and a graduating spray nozzle, and suction-pipe ready to mount on a barrel. Can be fitted with brass cylinder, plunger, and rod when so ordered.

on't buy an inferior machine when you can get a Perfection for less money.

We also manufacture the

\section{Victor Improved}

\section{Horse-Power}

\section{Spraying Machine.}

It is especially adapted for spraying Vineyards and orchards.

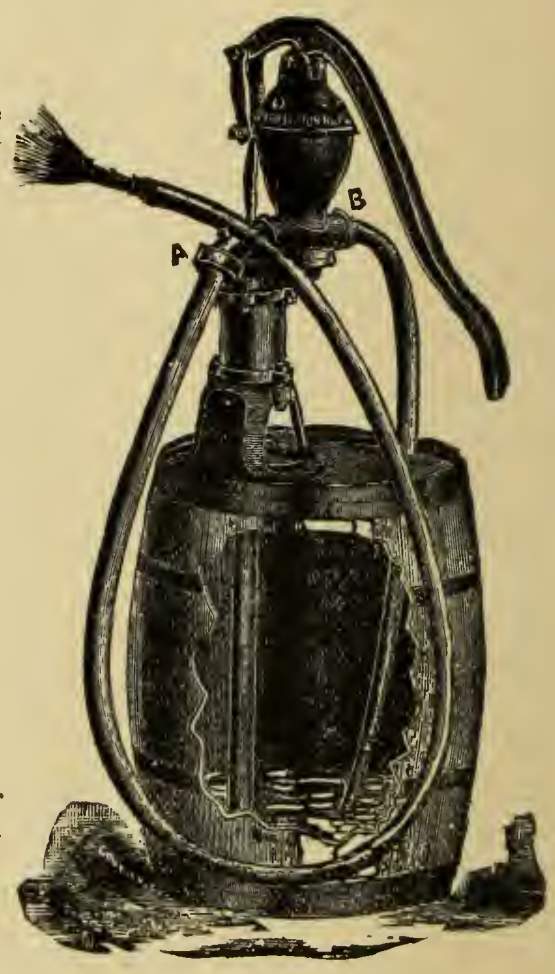

Our Machines are guaranteed first-chass in erery respect.

\section{FIELD FORCE PUMP COMPANY.}

Write for Circulars.

LockPor'T, NkW York. 


\section{The Garfield Knapsack Sprayer,}

FOR

Vineyards, Nurseries, Fruit Orchards, and
Potato Fields.

The only Innapsack that is Concared to Fit the Back.

This machine consists of a copper tank holding five gallons. The pump is made entirely of brass and copper, and cannot corrode or rust. There is a large air-chamber placed inside the tank for convenience, which has sufficient capacity to keep up the pressure and continue to discharge the spray for nearly one minute after the operator stops pumping. The tank, having rounded ends, is stronger and less liable to leak. It has handles for lifting, thus adding greatly to the convenience of "loading" upon the back. There

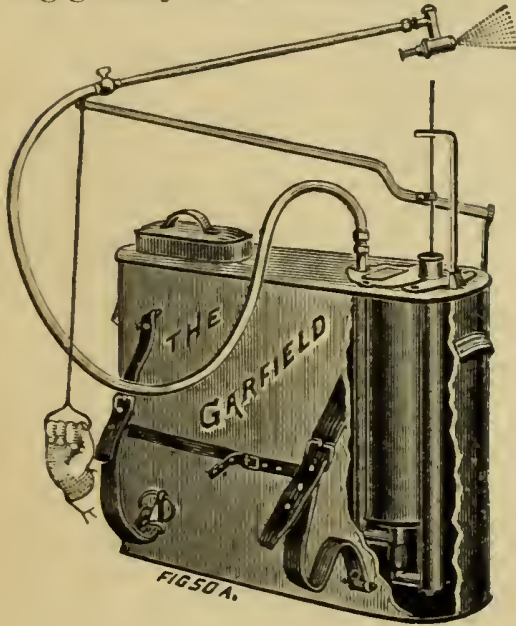
is a large opening on top for the reception of liquid, with a fine strainer set inside. A brass pipe, flfteen inches long, with a stop-cock, is furnished with each machine. The nozzle is our combination Vermorel, so highly recommended by Prof. Riley. and gives unirersal satisfaction. The Vermorel attachment throws a fine misty rapor spray, but on account of its fineness cannot be thrown more than fifteen feet. More force applied only serves to make the spray finer; but by means of the combination, the Vermorel attachment can be unscrewed, leaving it solid-stream nozzle, which will throw to a distance of 40 or 50 feet. Weight, empty, 14 lbs.; full, $60 \mathrm{lbs}$. 
To Farmers, Fruit Growers, \&c.:

London Purple has been used for a period exceeding fifteen years by farmers, fruit-growers, and all sorts of people for destroying insect pests.

Applied as a spray, $4 \mathrm{oz}$. to a barrel of water (to which a small quantity of lime should be added) it protects the tree against caterpillars and all leaf-eating insects, bringing it to that point of hardiness and healthiness which allows of the largest yield of the finest fruit.

London Purple can be obtained generally throughout the country, or direct from the manufacturers. HEMINGWAY'S LONDON PURPLE CO. LD. N. Y. 


\section{TEN NEW ENGLAND BLOSSOMS AND THEIR INSECT' VISITTORS}

BY CLARENCE MOORES WEED.

This beatifully illustrated book consists of of ten popular essays upon the relations of flowers and insects-one of the most interesting subjects in natural history. The curious contrivances by which flowers in. duce insects to carry the pollen from blossom to blossom, are described, and the adaptations of insects for this work are also discussed

The book contains half-tone plates of nearly all the flowers treated of, as well as illustrations of many insects.

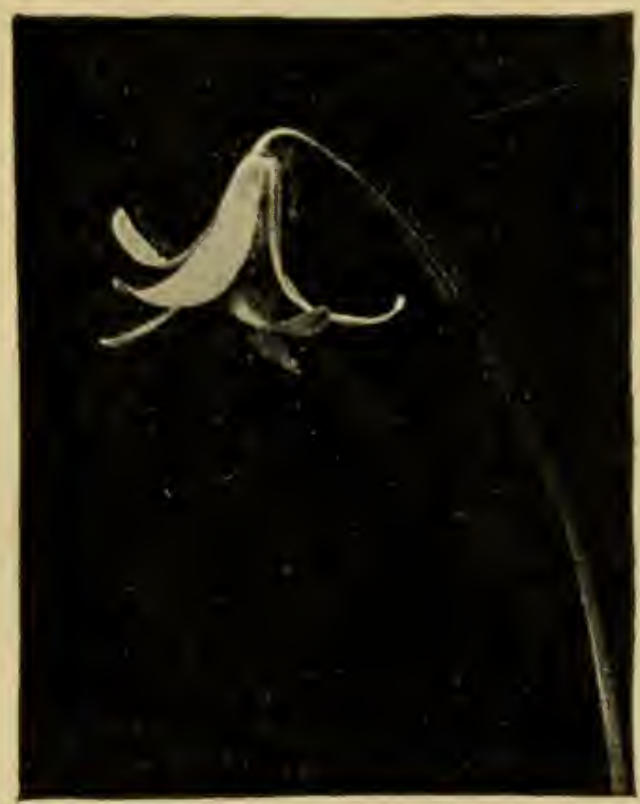

Houghton, Mifflin \& Co., Boston and New York.

\section{AMERICAN GARDENING,}

\section{A PRACTICAL JOURNAL OF HORTICULTURE.}

Published on behalf of all engaged in the cultiration of fruits, flowers and regetables, whether for pleasure or for profit.

Combining the experience of experts in every branch, unbiased and independent, AMERICAN GARDENING stands in the front ranks, and no one should be without it.

\section{ONE DOLLAR A YEAR. SPECIMEN FREE ON APPLICATION.}

AMERICAN GARDENING,

Rhinelander Building, New York. 


\section{DE M I N G}

\section{SPRAY PUMPS AND NOZZLES.}

Received Highest World's Fair Awards.

The best line of

"UP TO DATE" SPRAYING OUTFITS

in the world.

Sold by the hardware, farm implement and seed trade generally. Recommended by agricultural experiment stations and leading horticulturists.
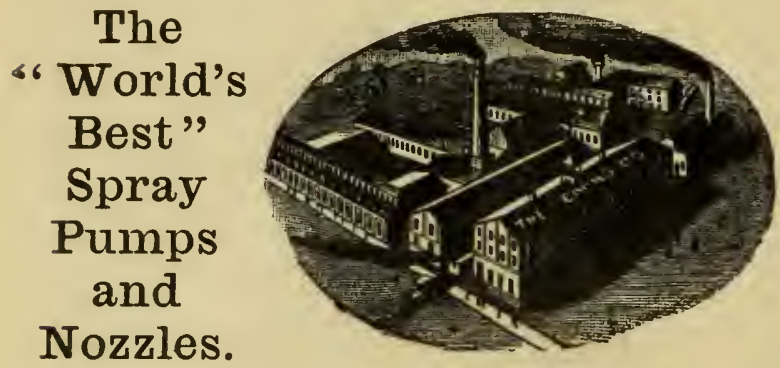

Received Highest Awards

at World's Fair, 1893.

We manufacture the "Success" and "Gem" bucket pumps; "Deming," "Ideal," and "Peerless" barrel pumps; "Perfected Galloway" 'knapsack sprayer, with or without Weed Kerosene Attachment, (dispenses with Kerosene Emulsion); "Bordeaux" and - Deming-Vermorel" nozzles, spraying appliances, etc.

Our 1895 illustrated catalogue contains latest recipes for Insecticirles and Fungicides with directions for using our spray pumps and nozzles. May be had for the asking. Address

\section{THE DEMING COMPANY,}

Manufacturers of

\section{Hand, Wind Mill, and Power Pumps, Hydrau- lic Rams, etc.}

S A L F M, - - - - - - - Ohio.

Western Agents: HENION \& IUUBBELL, Chicago.

New England Agents: JOSEPH BRECK \& SONS, Boston. 


\section{THE "IDEAL"}

DOUBLE-ACTING BRASS SPRAY PUMP, ("CILCK PUMI"')

With Brass Wing Piston, Valves and Valve Box.

Fig. 963.

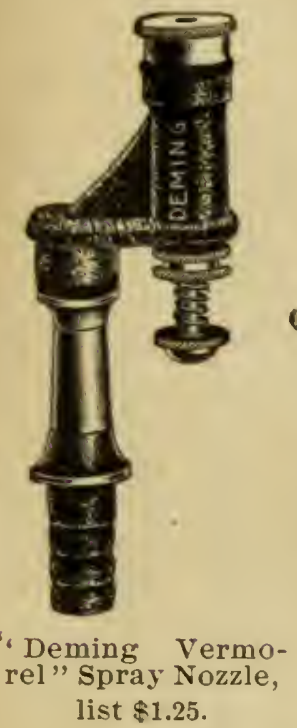

Fig. 571.

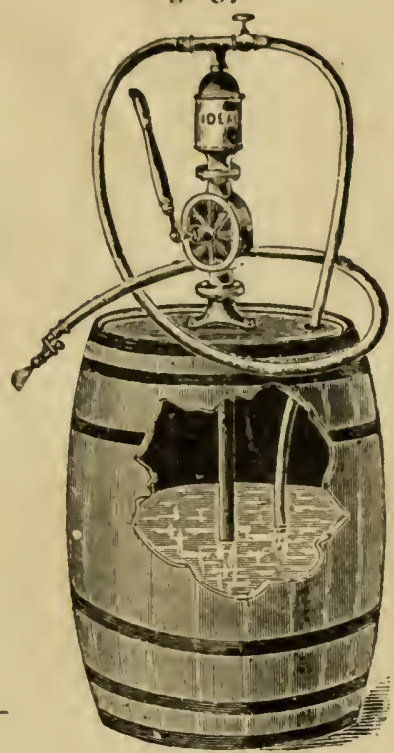

'Ideal' Clock Pump.
Fig. 965 .

\section{DESCRIPTION, SIZES AND PRICES OF FIG. 57 I.}

Pump Only. Fig. 571. With $2 \frac{1}{2}$ foot of 1 -inch suction pipe and strainer and double discharge "Y" connection, Fig. 364, with tight cap and hose connection. Prices:

No. 1, \$14.00; No. $2, \$ 18.50$.

Outfit B. B. Fig. 571, Spray Pump with $2 \frac{1}{2}$ feet of 1 -inch suction pipe and strainer. Double discharge "Y" connection with tight cap, $121 / 2$ feet of $1 / 2$-inch hose, "Deming Vermorel" nozzle and pole connection. Prices: $\quad$ No. $1, \$ 18.50 ;$ No. $2, \$ 23.00$.

Outfit C. C. Fig. 571. Spray Pump with 21/2 feet of 1 -inch suction pipe and strainer, $121 / 2$ feet of $1 / 2$-inch $d$ ischarge hose and "Deming Vermorel" nozzle and pole connection, also 5 feet of Agitator hose. A Stop Cock is provided to shut off Agitator. The Agitator discharge may also be used for spraying. Prices:

No. $1, \$ 23.00$; No. $2, \$ 27.50$.

The above prices are for Pumps with Iron Air Chamber; furnished with Brass Air Chamber at $\$ 3.00$ extra list. The base does not come in contact with the liquid and is always furnished of iron.

\section{Manufactured by THE DEMING COMPANY, Salem, Ohio.}

For sale by the Hardware, Farm Implement and Seed trade generally. Send for 24-page illustrated catalogue, and special prices of Spray Pumps, Nozzles and appliances. The largest line and the "World's" best. See other pages containing our advertisement. 


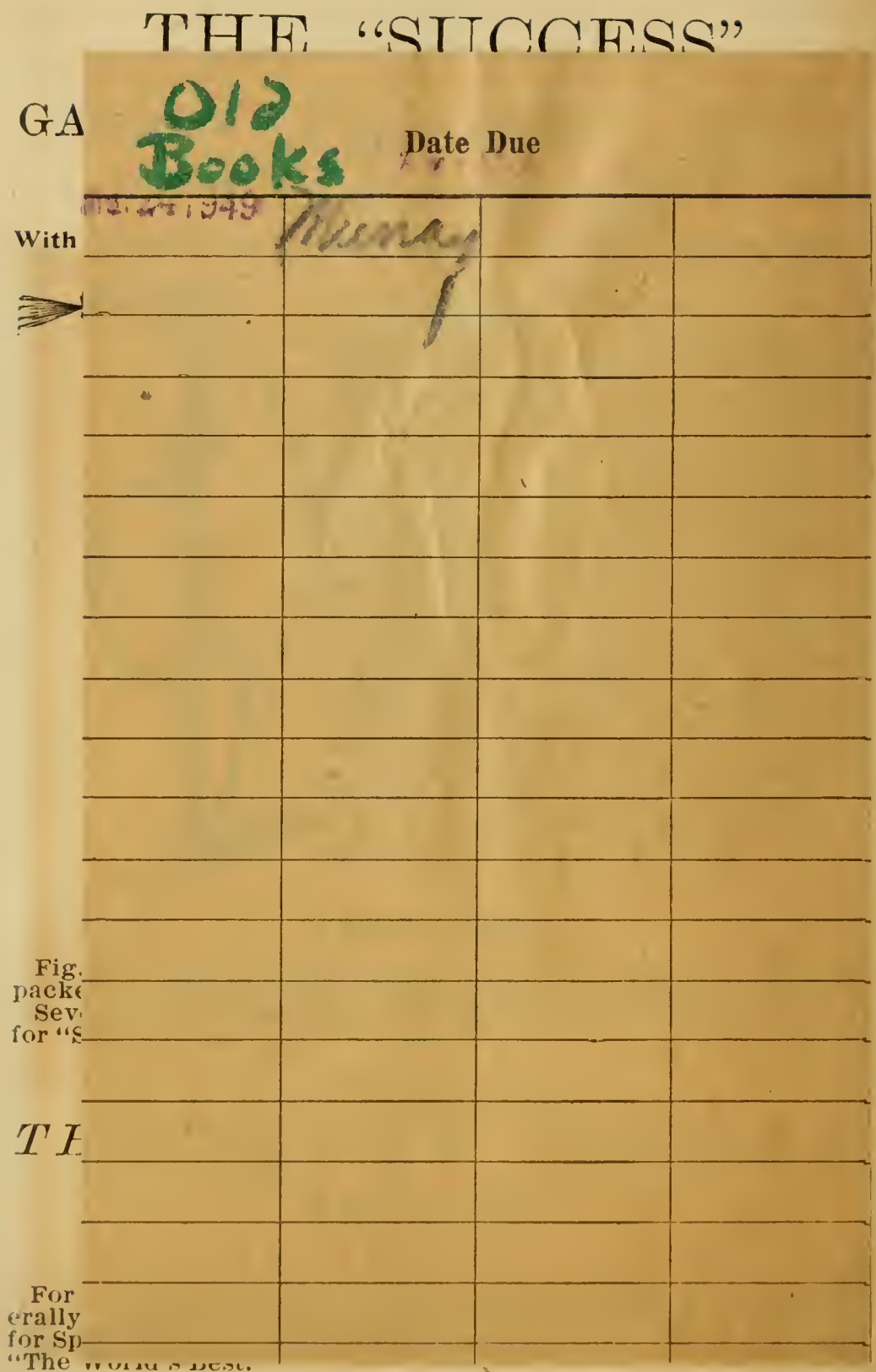

"The description and Price List of Galloway Sprayer on another page. 


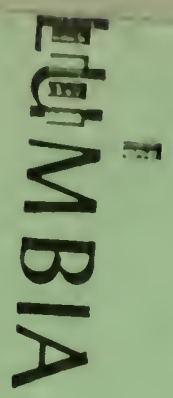

$$
\text { 寻 }
$$

FDRESTRY AGRICLLTURE LIZRARY 

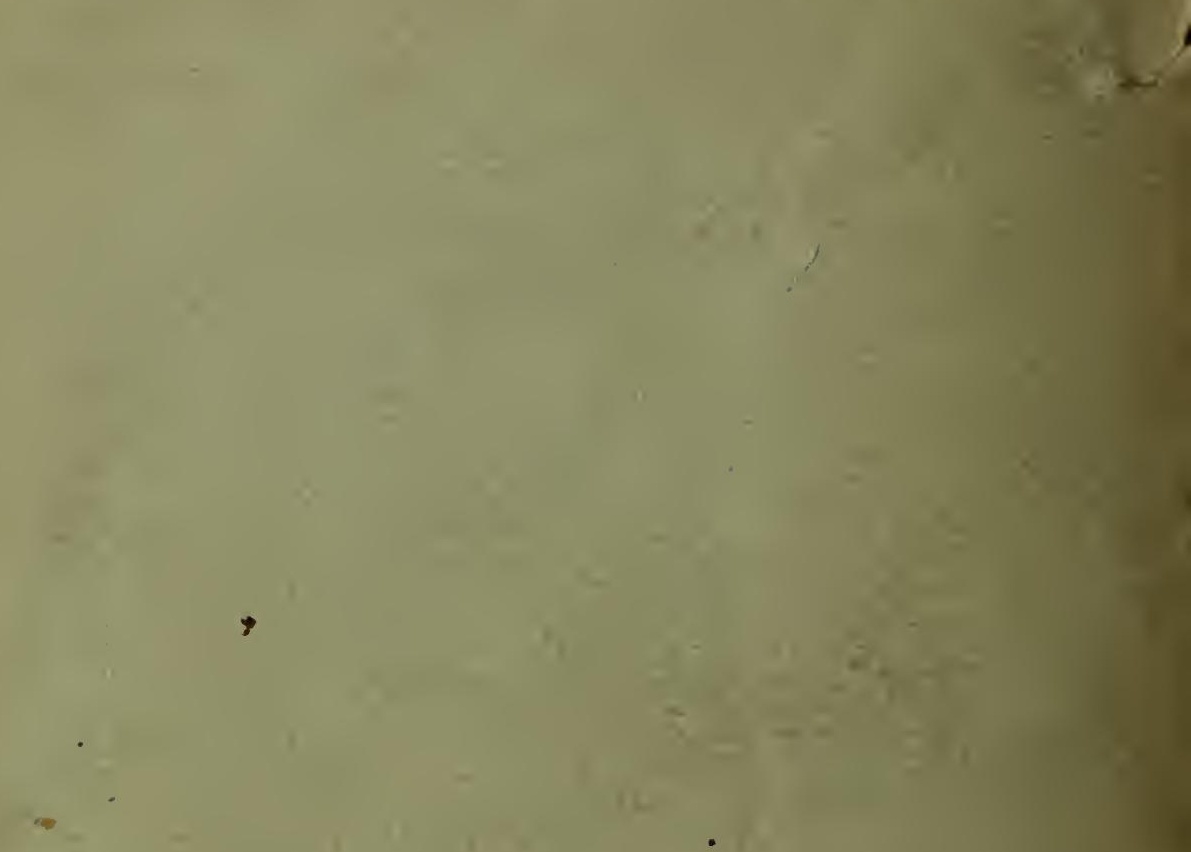

$+$

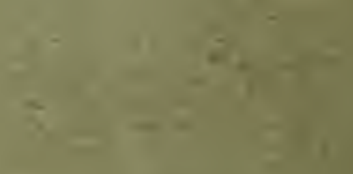

-

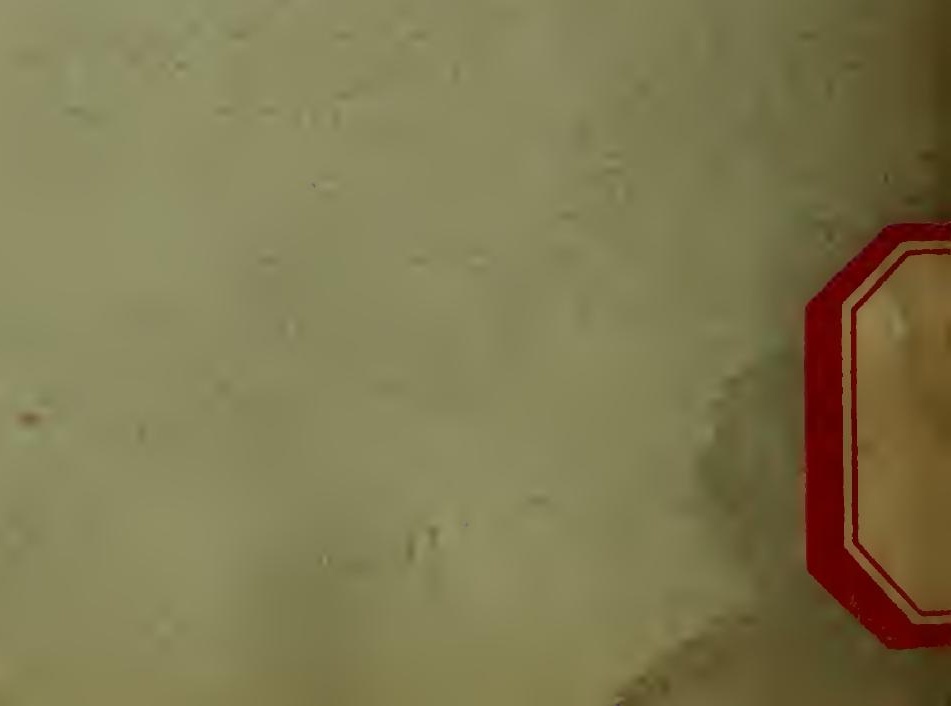

